
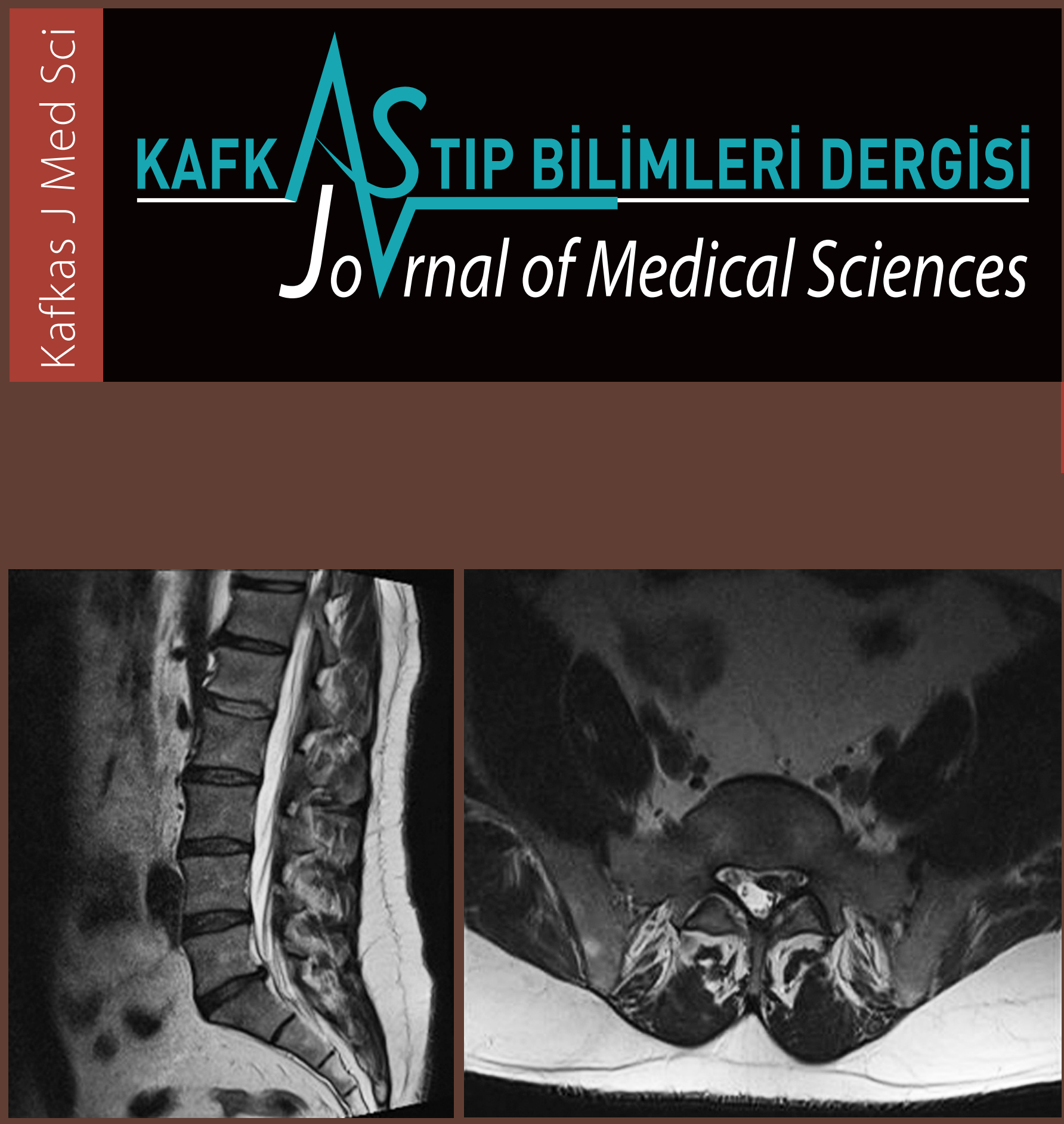

http://meddergi.kafkas.edu.tr e_mail: meddergi@kafkas.edu.tr 


\section{Kafkas Tıp Bilimleri Dergisi}

Kafkas Tıp Bilimleri Dergisi, Kafkas Üniversitesi Tıp Fakültesi'nin akademik yayın organıdır.

\begin{tabular}{|c|c|}
\hline Kuruluș tarihi & : 04.03.2011 \\
\hline Yayın türü & : Hakemli süreli yayın. \\
\hline Yayının adı & $\begin{array}{l}\text { : Kafkas Tıp Bilimleri Dergisi, Kafkas } \\
\text { Journal of Medical Sciences. }\end{array}$ \\
\hline Kısaltılmıș adı & : Kafkas J Med Sci. \\
\hline \multicolumn{2}{|c|}{ Yayımlanma ortamları: Matbu ve elektronik. } \\
\hline Peryodu & : 4 ayda bir (Nisan, Ağustos, Aralık) \\
\hline Yayın dili & : Türkçe ve İngilizce. \\
\hline Yazı içeriği & $\begin{array}{l}\text { : Tıp bilimleri ile ilgili araștırma, kısa bildiri, } \\
\text { derleme, editöryal, editöre mektup, } \\
\text { çeviri, tıbbi yayın tanıtma vb türlerden } \\
\text { yazılar yayımlanır. }\end{array}$ \\
\hline DOI numarası & $\begin{array}{l}\text { : Yayımlanan her bir makaleye dijital } \\
\text { nesne tanımlayıcı numarası (doi) atanır. }\end{array}$ \\
\hline Makale ișlemleri & $\begin{array}{l}\text { : Makale toplama ve değerlendirme ișlemleri } \\
\text { http://194.27.41.48/meddergi/jvi.asp } \\
\text { web adresinden online yapılır. }\end{array}$ \\
\hline
\end{tabular}

Endekslenme

\section{тÜBITAK-ULAKBIM \\ Türkiye Atıf Dizini \\ Türk Medline}

\section{Yönetim}

Yrd. Doç. Dr. B. Çağlar Bilgin (Imtiyaz Sahibi)

Doç. Dr. Kahraman Ülker (Yazı Ișleri Müdürü)

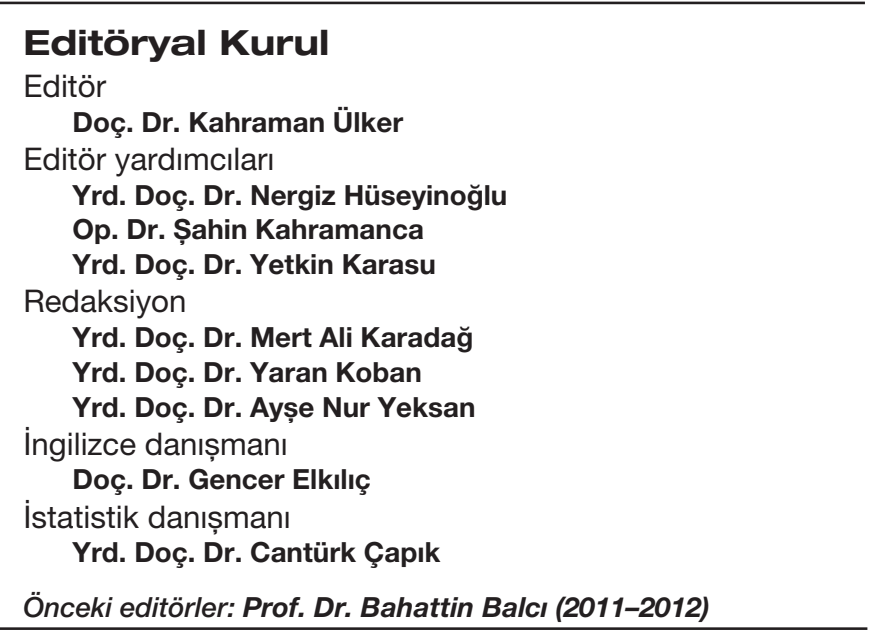

\section{Danıșma Kurulu (Ağustos 2014)}

Ahmet Karakurt, Kars

Ali Kurt, Erzurum

Ali Memiș, Ankara

Bahattin Balcı, Kars

Bahar Keleș, Konya

Barlas Sülü, Kars

Bașar Erdivanlı, Rize

Burhan Hakan Kanat, Elazığ

Cantürk Çapık, Kars

Cem Mat, İstanbul

Emin Silay, Kahraman Maraș

Emine Derviș, Kars

Erol Tașdemiroğlu, İstanbul

Fatih Mehmet Avșar, Kars

Kahraman Ülker, Kars

Kazım Doğan, Ardahan

Kürșat Çeçen, Kars

Miktat Kaya, Kars

Șahin Kahramanca, Kars

Tolga Sinan Güvenç, İstanbul

Yakup Tokmak, Rize

Yiğit Akın, Erzincan

Yusuf Günerhan, Kars

Zekayi Kutlubay, İstanbul

\section{Iletișim}

Kafkas Tıp Bilimleri Dergisi

Kafkas Üniversitesi, Tıp Fakültesi

36300 Kars, Türkiye

Tel. 4742251196

Fax. 4742251193

E-mail. medical.dergi@kafkas.edu.tr

Web. http://194.27.41.48/meddergi/jvi.asp

\section{Yayın Hizmetleri}

Tasarım ve Uygulama

BAYT Bilimsel Araștırmalar

Basın Yayın ve Tanıtım Ltd. Ști.

Ziya Gökalp Cad. 30/31, Kızılay-Ankara

Tel. (312) 4313062

www.bayt.com.tr

\section{Baskı}

Miki Matbaacılık Ltd. Ști.

Matbaacılar Sitesi, 560 Sk. No:27, İvedik-Ankara

Tel. (312) 3952128

Baskı Tarihi

25 Ağustos 2014 


\section{Kafkas Journal of Medical Sciences}

Kafkas Journal of Medical Sciences is the official academic publication of Kafkas University School of Medicine.

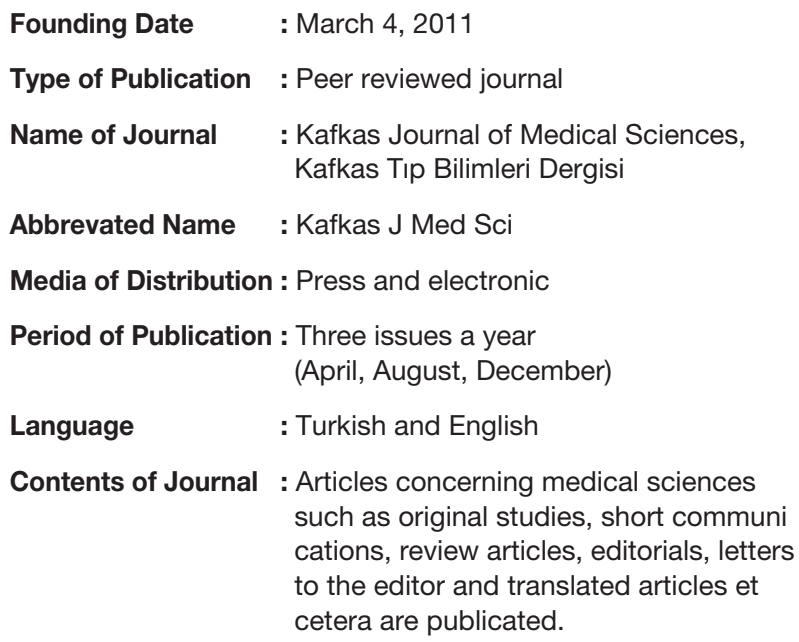
such as original studies, short communi cations, review articles, editorials, letters to the editor and translated articles et cetera are publicated.

DOI number : : A digital object identifier (doi) number is assigned to all articles accepted for publication.

Manuscript Processing : Manuscript submission and review procedures are performed online at http://194.27.41.48/meddergi/jvi.asp

\section{Indexed in}

\section{TÜBITAK-ULAKBIM \\ Türkiye Atıf Dizini \\ Türk Medline}

\section{Administration}

Assist. Prof. Dr. B. Cağlar Bilgin (Owner)

Associate Prof. Dr. Kahraman Ülker (Publishing Manager)

\section{Editorial Board}

Editor

Associate Prof. Dr. Kahraman Ülker

Associate Editors

Assist. Prof. Dr. Nergiz Hüseyinoğlu

M.D. Dr. Sahin Kahramanca

Assist. Prof. Dr. Yetkin Karasu

Redaction

Assist. Prof. Dr. Mert Ali Karadağ

Assist. Prof. Dr. Yaran Koban

Assist. Prof. Dr. Ayșe Nur Yeksan

English Consultant

Associate Prof. Dr. Gencer Elkılıç

Statistical consultant

Assist. Prof. Dr. Cantürk Çapık
Advisory Board (August 2014)

Ahmet Karakurt, Kars

Ali Kurt, Erzurum

Ali Memiș, Ankara

Bahattin Balcı, Kars

Bahar Keleș, Konya

Barlas Sülü, Kars

Bașar Erdivanlı, Rize

Burhan Hakan Kanat, Elazığ

Cantürk Çapık, Kars

Cem Mat, İstanbul

Emin Silay, Kahraman Maraș

Emine Derviș, Kars

Erol Tașdemiroğlu, İstanbul

Fatih Mehmet Avșar, Kars

Kahraman Ülker, Kars

Kazım Doğan, Ardahan

Kürșat Çeçen, Kars

Miktat Kaya, Kars

Sahin Kahramanca, Kars

Tolga Sinan Güvenç, İstanbul

Yakup Tokmak, Rize

Yiğit Akın, Erzincan

Yusuf Günerhan, Kars

Zekayi Kutlubay, İstanbul

\section{Correspondence}

Kafkas Tıp Bilimleri Dergisi

Kafkas Üniversitesi, Tıp Fakültesi

36300 Kars, Turkey

Phone. +90 4742251196

Fax. +90 4742251193

E-mail. medical.dergi@kafkas.edu.tr

Web. http://194.27.41.48/meddergi/jvi.asp

\section{Publication Services}

Graphic Design

BAYT Bilimsel Araștırmalar

Basın Yayın ve Tanıtım Ltd. Ști.

Ziya Gökalp Cad. 30/31, Kızılay-Ankara, Turkey

Phone. +903124313062

www.bayt.com.tr

Printing

Miki Matbaacllık Ltd. Ști.

Matbaacılar Sitesi, 560 Sk. No:27, İvedik-Ankara, Turkey

Phone. +90 3123952128

Printing Date

August 25, 2014 
ISSN 1307-4504

\section{İçindekiler / Contents}

\section{ARAȘTIRMA YAZISI / ORIGINAL ARTICLE}

\section{Accessory Nerve Root and Associated Dural Injury Incidences Encountered During Lumbar}

Microdiscectomy

Lomber Mikrodiskektomi Esnasında Rastlanan Aksesuar Sinir Kökü ve Dural Yaralanma Sıklı̆ı̆ı

Șeyho Cem Yücetaș, Can Hakan Yıldırım, Mehmet Bülent Balioğlu, Yusuf Ehi, Ahmet Faruk Soran, Aytaç Akbașak doi: $10.5505 / \mathrm{kjms} .2014 .83702$

Correlation of Cardiovascular Limitations and Symptoms Profile with the Quality of Life, Anxiety and

Depression Scales.

Kardiyovasküler Kısıtılık ve Semptomlar Profilinin Yașam Kalitesi, Anksiyete ve Depresyon Skalaları ile İlișkisi

Derya Özcanlı Atik, Sezgi Çınar

doi: 10.5505/kjms.2014.28863

Parotid Kitlelerinin Değerlendirilmesinde İnce İğne Aspirasyon Biyopsisi ile Histopatolojinin

Karșılaștırılması

Comparison of Fine Needle Aspiration Biopsy and Histopathology in the Evaluation of Parotid Masses

Ali Osman Özbey, Fatih Bora, Ahmet Kutluhan, Mahmut Duymuș, Kazım Bozdemir

doi: 10.5505/kjms.2014.96658

Ameliyat Sonrası Ağrı Yönetiminde Nitelik Değișimi: İki Periyodun Karșılaștırılması.

Quality Changes in Postoperative Pain Management: Comparison of Two Periods

Elif Dirimeșe, Meryem Yavuz, Yasemin Altınbaș

doi: $10.5505 / \mathrm{kjms} .2014 .29200$

\section{DERLEME / REVIEW}

Prophylactic Use of Non-invasive Ventilation After Abdominal and Thoracic Surgery

Non-invazif Ventilasyonun Abdominal ve Torasik Cerrahi Sonrası Profilaktik Kullanımı

Ayșe Nur Yeksan, Cafer Mutlu Sarıkaș, Ürfettin Hüseyinoğlu, Sadık Avșar

doi: 10.5505/kjms.2014.48569

\section{OLGU SUNUMU / CASE REPORT}

Transitional Cell Carcinoma Recurrence in the Nephrostomy Tract After Percutaneous Nephrolithotomy

Perkütan Nefrolitotomi Sonrasında Nefrostomi Hattında Transizyonel Hücreli Karsinom Rekürrensi

Mustafa Sofikerim, Mert Ali Karadağ, Emrecan Akınsal, Fikret Halis

doi: 10.5505/kjms.2014.73645

Non-Traumatic Pseudocyst of the Spleen: A Case Report .

Dalağın Travmatik Olmayan Psödokisti: Bir Olgu Sunumu

Metin Șenol, Hakan Özdemir, Ibrahim Tayfun Șahiner, Zehra Ünal Özdemir

doi: 10.5505/kjms.2014.24008

Discrete Papular Lichen Myxoedematosus: A Case Report

Diskret Papüler Liken Miksödematöz: Bir Olgu Sunumu

Fatma Pelin Cengiz

doi: 10.5505/kjms.2014.04706 


\title{
Accessory Nerve Root and Associated Dural Injury Incidences Encountered During Lumbar Microdiscectomy
}

\author{
Lomber Mikrodiskektomi Esnasında Rastlanan Aksesuar Sinir Kökü ve Dural Yaralanma Sıklığı
}

\author{
Șeyho Cem Yücetaș', Can Hakan Yıldırım', Mehmet Bülent Balioğlu², Yusuf Ehi³, Ahmet Faruk Soran4, \\ Aytaç Akbașak ${ }^{1}$ \\ ${ }^{1}$ Department of Neurosurgery, Kafkas University Faculty of Medicine, Kars, Turkey; ${ }^{2}$ Baltaliman Education and Research Hospital, \\ Istanbul, Turkey; ${ }^{3}$ Department of Neurology, Kafkas University Faculty of Medicine, Kars, Turkey; ${ }^{4}$ Department of Neurosurgery, \\ Harran University Faculty of Medicine, Şanluurfa, Turkey
}

\section{ABSTRACT}

AIM: We aimed to find the incidence of accessory nerve roots and their respective sites encountered intraoperatively during lumbar microdiscectomy operations, and to draw attention to the findings associated with the presence of accessory nerve roots.

METHODS: This study was conducted by retrospective analysis of the records of patients $(N=820)$ who were operated by the method of microdiscectomy in three medical centers between April 2010 and August 2013. Cases that indicated surgery upon neurological and radiological examinations were included in the study. In the study, accessory nerve root abnormalities and the related dural tears or nerve root injuries were assessed.

The variables of sex, presence of accessory roots and dural injury were used as independent variables to analyze the other variables.

RESULTS: Accessory nerve root anomaly was detected in 22 (3\%) of 820 operated patients. L4-5 was the most frequent level for hernia formation and followed by L5-S1 level. The hernia side, as right or left, did not significantly differ at any level ( $p>0.05)$.

L5-S1 space was the most frequent site for accessory nerve roots and followed by L4-5 space. However, the frequency of right or left side location of the accessory nerve roots were not different at any lumbar disc level ( $p>0.05)$.

The presence of an accessory nerve root increased the chance of dural tear injury. Female gender, independent from the presence of an accessory nerve root, was a risk factor for dural tear injury.

CONCLUSION: The accessory nerve root is most frequently observed at the L5-S1 disc level and its presence increases the chance of dural injury. In addition, female gender is an independent risk factor for dural injury.

Key words: accessory nerve root; dural tear; lumbar disc herniation; microdiscectomy

Yard. Doç. Dr. Seyho Cem Yücetas, Kafkas Üniversitesi 36100 Kars, Türkiye,

Tel.04742252106Email.seyhocem@hotmail.com

Geliş Tarihi: 22.01.2014 • Kabul Tarihi: 19.03.2014

\section{ÖZET}

AMAÇ: Çalıșmadaki amacımı lomber mikrodiskektomi girișimleri sırasında intraoperatif olarak karșılașılan aksesuar sinir kökü görülme ve yerleșim yeri sıklı̆̆ı sonuçlarımızı sunmak ve aksesuar root varlı̆̆ına ilișkin bulgulara dikkat çekmektir.

YÖNTEM: Bu çalıșma Nisan 2010 ile Ağustos 2013 tarihleri arasında mikrodisektomi yöntemiyle opere olan, üç merkezdeki hastaların ( $N=820)$ kayıtlarının retrospektif olarak incelenmesiyle yapıldı. Çalıșmaya nörolojik ve radyolojik muayeneler sonucu operasyon endikasyonu konulan olgular dahil edildi. Çalıșmada aksesuar sinir kökü anomalisi ve buna bağlı dura veya sinir kökü yaralanma oranları incelendi.

Cinsiyet, aksesuar sinir kökü ve dura yaralanması varlığı, diğer değișkenleri incelemek üzere bağımsız değișkenler olarak kullanıldı.

BULGULAR: Lomber aksesuar sinir kökü anomalisi opere edilen 820 hastanın 22'sinde (\%3) tespit edildi. L4-5 disk hernisi formasyonunda en çok rastlanan seviye olup, ikincisi ise L5-S1 seviyesiydi. Disk hernisinin sağ ya da sol tarafta olması, hiçbir seviyede dikkate değer bir farklılık olușturmamıștır ( $p>0,05)$.

Aksesuar sinir köklerinin en sık rastlanıldığı yerleșim yeri L5-S1 boșluğu olmuștur ve ikinci olarak L4-5 gelmektedir. Ancak aksesuar sinir köklerinin sağ ya da sol tarafta yerleșim sıklığı, hiçbir lomber disk seviyesinde farklı olmamıștır ( $p>0,05)$.

Aksesuar sinir kökü varlığı, dura yaralanması ihtimalini arttırmıștır. Aksesuar sinir kökü varlı̆̆ından bağımsız olarak cinsiyetin kadın olması, dura yaralanmalarında bir risk faktörü olmuștur.

SONUÇ: Aksesuar sinir kökü en sık L5-S1 disk aralığındadır. Aksesuar kökün varlığı, dura yaralanması ihtimalini arttırmaktadır. Ayrıca cinsiyetin kadın olması, dura yaralanmaları için bağımsız bir risk faktörüdür.

Anahtar kelimeler: aksesuar sinir kökü; dura yırtımasl; lomber disk hernisi; mikrodiskektomi 


\section{Introduction}

Disc herniation is the general name given to the medical condition presenting itself as a pathology that distorts the shape and content of the discus intervertebralis due to reasons other than infection or tumor ${ }^{1}$. Lumbar disc herniation is most frequently observed in the L4-5 level. Currently, surgical therapy is typically carried out by microdiscectomy; however many other surgical methods are also used ${ }^{2,3}$.

Although it is rare, the accessory nerve roots may be encountered intraoperatively during lumbar disc surgery and they are hardly defined before surgery by using magnetic resonance imaging (MRI) and computerized tomography (CT) modalities ${ }^{4}$.

Lumbosacral nerve root abnormalities are classified under five or six groups ${ }^{5}$. Awareness of an accessory nerve root abnormality reduces intraoperative injuries ${ }^{6}$. During surgery, certain complications may develop such as dural tear, nerve root injury and vascular injuries which are mostly due to anatomical variations or intraoperative difficulties of the exploration of the surgical field ${ }^{1,7}$. The demonstration of a conjoined nerve root abnormality within the operation field during lumbar microdiscectomy reduces dural tears or nerve root injuries ${ }^{4}$.

In this study, we aimed to find the incidence of accessory nerve roots and their respective sites encountered intraoperatively during lumbar microdiscectomy operations, and to draw attention to the findings associated with the presence of accessory nerve roots.

\section{Methods}

This retrospective study was conducted by the examination of the records of patients who underwent surgery in the brain and nerve surgery clinics of the Kafkas University School of Medicine, Harran University School of Medicine and the Adiyaman Training and Research Hospital. Before the examination of the files, the local medical ethics committees approved the study and the necessary approvals were also obtained from related institutions.

The population of the study consisted of patients indicated with operation as a result of neurological and radiological examinations. For sampling, the data of 820 patients who underwent microdiscectomy due to lumbar herniation between April 2010 and August 2013 in the three hospitals were used.

Patients with previous multiple operations at the same level, total or unilateral partial laminectomy, scoliosis or congenital vertebral abnormality were excluded. Discectomies secondary to trauma were also excluded.

All patients had had MRI examinations preoperatively and some of them had had additional CT imaging examination whereas it had been necessary. All patients' extruded or sequestered discs had been detected preoperatively by using MRI or CT imaging (Figures 1,2).

Study variables included demographics of the participants, the existence of accessory nerve root detected during microdiscectomy (Figure 3), the level and side of the accessory nerve root and the complication of dural tear.

Statistical analysis was performed by using SPSS 21.0 package program for windows (Chicago, USA). Constant variables were shown as mean \pm standard deviation whereas categorical variables were shown with median values. The incidences of accessory root and their locations, and the development of dural tear were evaluated using Chi-square test. Gender, presence/ absence of accessory nerve root and presence/absence of dural injury were used as independent variables to analyze the other variables. Variables with normal and non-normal distribution were compared with independent samples of Student $t$ and Mann Whitney tests, respectively. Correlation analysis among variables was performed by using Pearson's correlation test. A p value of $<0.05$ was considered significant.

\section{Results}

A total of 820 discectomy cases were evaluated. Of the included patients 440 and 380 were females and males, respectively. The youngest patient was 19 years old whereas the oldest one was 65 years old; the mean age of the patients was 42.6 years.

Lomber disc hernia localization levels were classified according to the intervertebral disc spaces as: L1-2, L2-3, L3-4, L4-5 and L5-S1 (Table 1). L4-5 was the most frequent level for hernia formation and followed by L5-S1 level. The hernia side, as right or left, did not significantly differ at any level $(\mathrm{p}>0.05)$.

L5-S1 space was the most frequent site for accessory nerve roots and followed by L4-5 space (Table 2). However, the frequencies of right or left side location of the accessory nerve roots were not different at any lumbar disc level $(\mathrm{p}>0.05)$.

All patients had preoperative motor and sensory loss. Lower leg was involved in four patients with conjoined nerve and in 15 patients without conjoined nerve. 


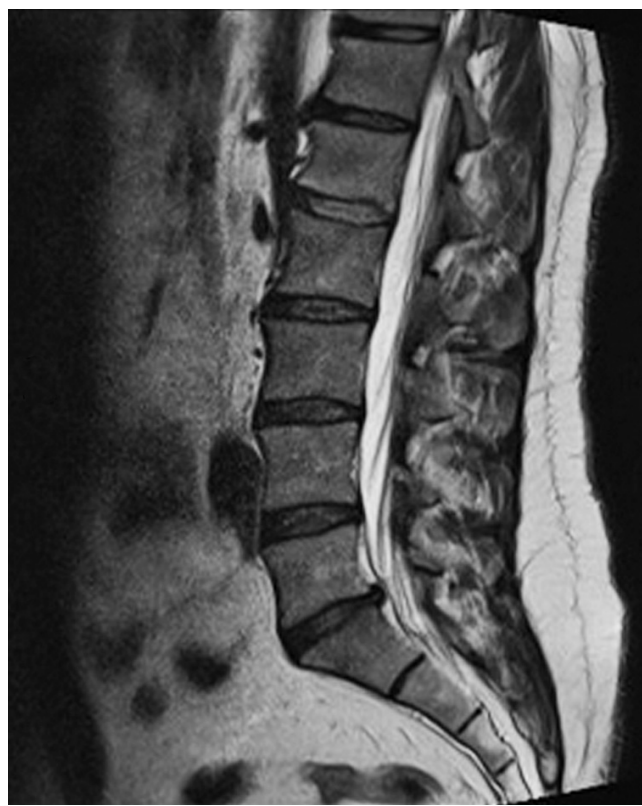

Figure 1. T2A sagittal MRI. L5-S1 lumbar disc herniation.

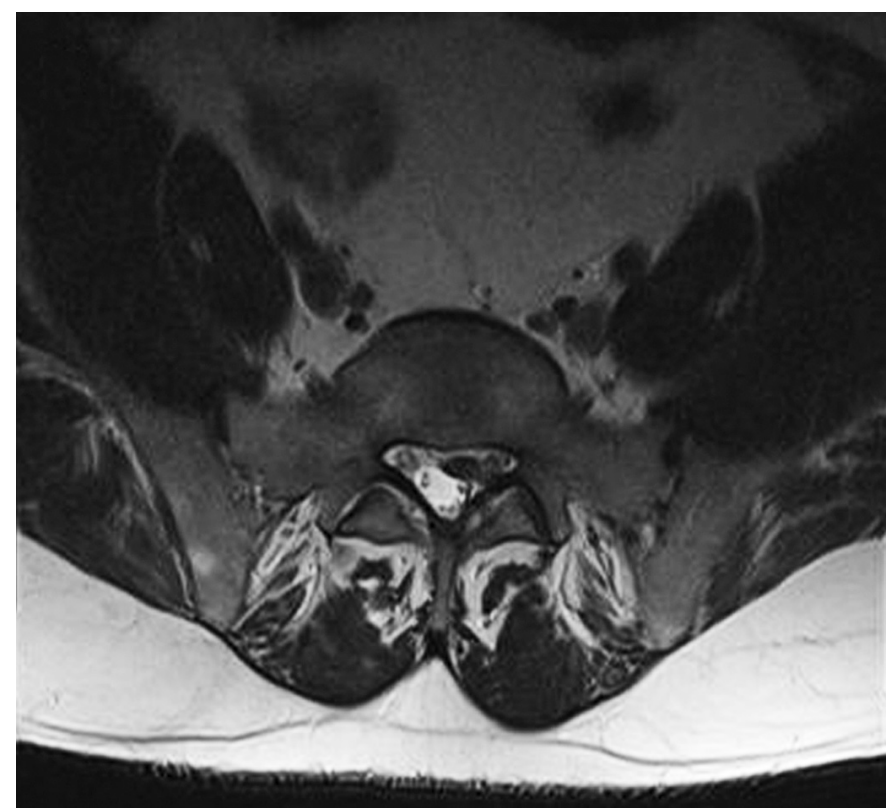

Figure 2. T2A axial MRI. L5-S1 lumbar disc herniation.

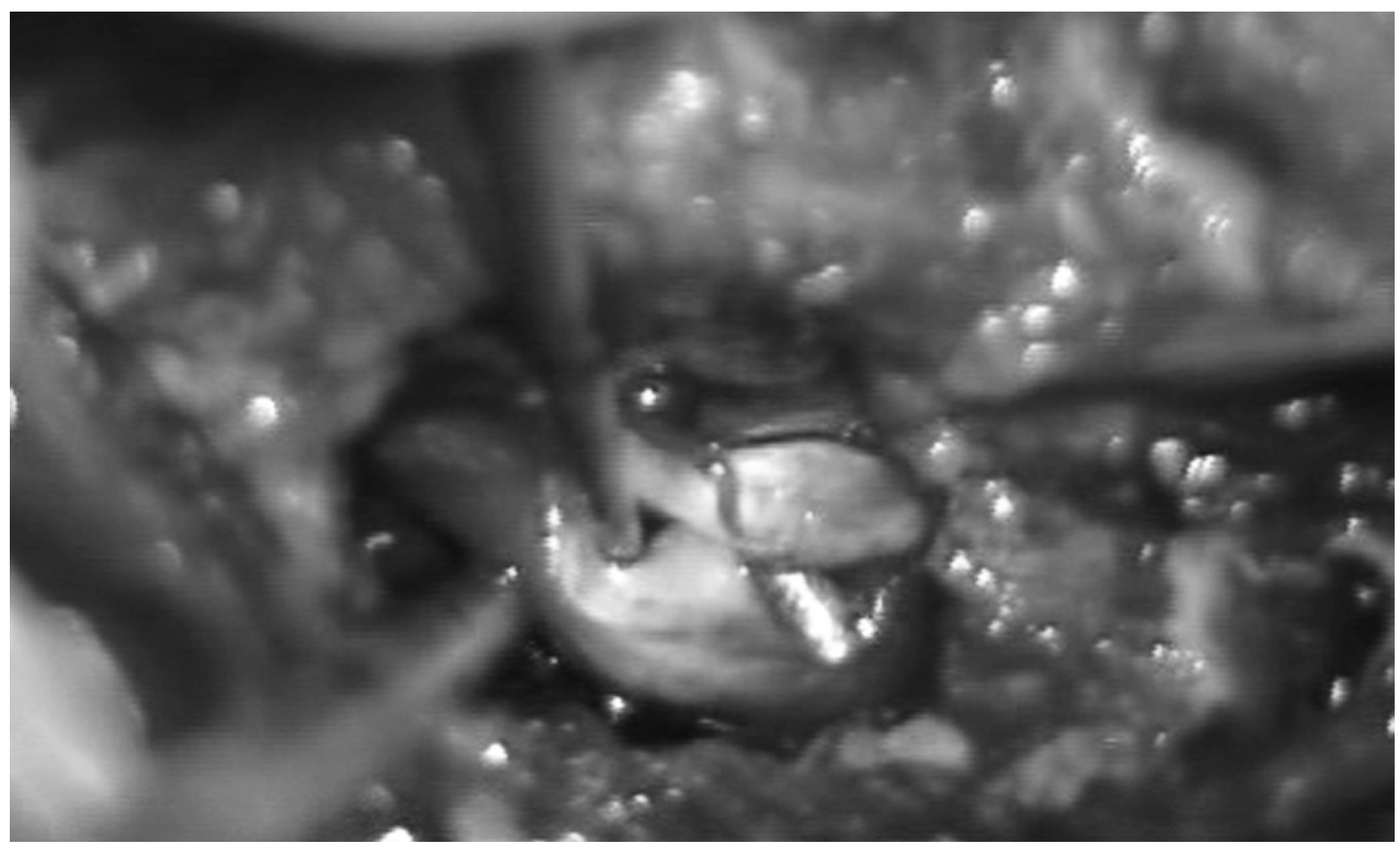

Figure 3. Intraoperative view of the accessory nerves.

Urinary incontinence was observed in three of the patients who had an accessory nerve root and in 13 of the patients, who did not. Cauda equina findings were observed in five patients, who did not have accessory nerve root and in one patient with an accessory nerve root.
Female and male patients were compared by using the variables of age, lumbar hernia level, left and right sided hernia, presence of accessory nerve root and occurrence of dural tear injury (Table 3 ). Dural tear injury was significantly higher in female patients $(p<0.05)$, 
Table 1. Distribution of operated disc hernias at the lumbar region

\begin{tabular}{|c|c|c|c|c|c|}
\hline \multirow[b]{2}{*}{ Lumbar disc level } & \multicolumn{2}{|c|}{ Right sided $(n=413)$} & \multicolumn{2}{|c|}{ Left sided $(n=407)$} & \multirow[b]{2}{*}{$\mathrm{p}^{*}$} \\
\hline & $\mathrm{n}$ & $\%$ & $\mathrm{n}$ & $\%$ & \\
\hline L1-2 & 3 & 0.7 & 4 & 0.9 & 0.705 \\
\hline L2-3 & 12 & 3 & 8 & 2 & 0.371 \\
\hline L3-4 & 28 & 7 & 26 & 6 & 0.785 \\
\hline L4-5 & 222 & 53.7 & 197 & 48.4 & 0.222 \\
\hline L5-S1 & 148 & 36 & 172 & 42.3 & 0.180 \\
\hline
\end{tabular}

Table 2. Distribution of accessory nerve roots at the lumbar region

\begin{tabular}{|c|c|c|c|c|c|}
\hline \multirow[b]{2}{*}{ Lumbar disc level } & \multicolumn{2}{|c|}{ Right sided ( $n=13$ ) } & \multicolumn{2}{|c|}{ Left sided $(n=9)$} & \multirow[b]{2}{*}{$p$ value* } \\
\hline & $\mathrm{n}$ & $\%$ & $\mathrm{n}$ & $\%$ & \\
\hline L1-2 & 0 & 0 & 0 & 0 & $\mathrm{n} / \mathrm{a}$ \\
\hline L2-3 & 0 & 0 & 0 & 0 & $\mathrm{n} / \mathrm{a}$ \\
\hline L3-4 & 1 & 8 & 0 & 0 & 0.335 \\
\hline L4-5 & 2 & 15 & 3 & 33 & 0.559 \\
\hline L5-S1 & 10 & 77 & 6 & 77 & 0.182 \\
\hline
\end{tabular}

Table 3. Comparison of study findings according to the independent variables of gender, presence of accessory nerve root and presence of dural injury

\begin{tabular}{|c|c|c|c|}
\hline & Female patients $(n=440)$ & Male patients $(\mathrm{n}=380)$ & $\mathrm{p}$ value \\
\hline Age, year & $42.7 \pm 12.6$ & $42.5 \pm 13.5$ & $0.888^{*}$ \\
\hline Hernia disc level & L4-5 & L4-5 & $0.873^{\star *}$ \\
\hline Right side hernia, \% & 48 & 53 & $0.228^{\star \star}$ \\
\hline Left side hernia, \% & 52 & 47 & $0.228^{\star *}$ \\
\hline Accessory root, \% & 3 & 2 & $0.605^{\star \star}$ \\
\hline \multirow[t]{2}{*}{ Dural injury, \% } & 6 & 2 & $0.018^{\star \star}$ \\
\hline & Accessory nerve root present $(n=22)$ & Accessory nerve root absent $(n=798)$ & \\
\hline Female patients, $\%$ & 59 & 54 & $0.605^{\star \star}$ \\
\hline Male patients, $\%$ & 41 & 46 & $0.605^{\star \star}$ \\
\hline Age, year & $44.5 \pm 12.2$ & $42.6 \pm 12.9$ & $0.489^{\star}$ \\
\hline Hernia disc level & L5-S1 & L4-5 & $0.002^{\star *}$ \\
\hline Right side hernia, \% & 59 & 50 & $0.407^{\star \star}$ \\
\hline Left side hernia, \% & 41 & 50 & $0.407^{\star \star}$ \\
\hline \multirow[t]{2}{*}{ Dural injury, \% } & 27 & 4 & $<0.001^{\star \star}$ \\
\hline & Dural injury occured $(n=34)$ & Dural injury did not ocur ( $n=786$ ) & \\
\hline Female patients, $\%$ & 74 & 43 & $0.012^{*}$ \\
\hline Male patients, $\%$ & 26 & 47 & $0.012^{*}$ \\
\hline Age, year & $41.4 \pm 12.6$ & $42.7 \pm 12.9$ & $0.577^{\star}$ \\
\hline Hernia disc level & L4-5 & L4-5 & $0.472^{\star *}$ \\
\hline Right side hernia, \% & 56 & 50 & $0.511^{\star *}$ \\
\hline Left side hernia, \% & 44 & 50 & $0.511^{\star *}$ \\
\hline Accessory root, \% & 18 & 2 & $<0.001^{\star *}$ \\
\hline
\end{tabular}


however other variables did not differ significantly between female and male patients ( $p>0.05)$.

The patients with or without an accessory nerve root were compared with each other by using the variables of gender, age, lumbar hernia level, left and right sided hernia, and occurrence of dural tear injury (Table 3). Lumbar hernia level was significantly lower in patients with an accessory nerve root in comparison with the patients without an accessory nerve root $(p<0.05)$. However, other variables were not affected by the presence or absence of an accessory nerve root ( $\mathrm{p}>0.05)$.

Operations complicated with a dural tear injury were compared with operations without a complication by using the variables of gender, age, lumbar hernia level, left and right sided hernia, and presence of an accessory nerve root (Table 3). Dural tear injury was significantly higher in female patients and in patients with an accessory nerve root $(p<0.05)$. However; age, lumbar hernia level and side did not differ in operations complicated or not with a dural tear injury $(\mathrm{p}>0.05)$.

Correlation analysis showed that the chance of presence of an accessory nerve increased in lower lumbar hernias and presence of an accessory nerve root increased the chance of a dural injury $(p<0.05)$.

\section{Discussion}

\section{Principal findings}

Our study findings suggested that accessory nerve roots were encountered in lower level lumbar hernias, particularly the hernias involving L4-5 and L5-S1. The presence of an accessory nerve root increased the chance of dural tear injury and female gender independent from the presence of an accessory nerve root was a risk factor for dural tear injury.

\section{Strengths and limitations}

To our knowledge, this is the first study including such a large sample of 820 patients. In addition, our study population included patients from three different centers located in different cities. Although, the study population included only the symptomatic patients, the relation of the presence of an accessory nerve root and intraoperative dural injury is also important in this population.

Although our study included 820 operations performed with microdiscectomy technique, it was a retrospective study and some variables could not be analyzed. For example, the lack of variables of patients' height and weight kept us from analyzing the differences between female and male patients. Probably the shorter female patients had narrower intervetebral disc spaces, which made the surgical exposure harder. Thus, it is hard to demonstrate whether the higher injury rate resulted from the female gender or narrower intervertebral disc spaces.

\section{Comparison with previous studies}

Lumbar disc herniation was defined by Mixer and Barr in 1934 . In their lifetime, about $80 \%$ of the adult population experiences an episode of backaches that affect their functionality and some of these episodes are related to disc conditions ${ }^{1,8}$.

Many methods are used in the diagnosis of lumbar disc herniation, but currently, the mostly preferred methods are MRI and CT imaging ${ }^{4,9,10}$. Lumbar disc herniation typically develops in L4-5 and L5-S1 levels and in less than $5 \%$ of the instances, it develops in other regions ${ }^{11}$. In our patients, the distribution of sites was similar, in that approximately $90 \%$ developed in L4-5 and L5-S1 levels. Patients may present with radicular pain, motor and sensory loss, reflex changes, urinary and fecal incontinence and cauda equina syndrome findings ${ }^{8,12}$. In all patients we operated, there was motor and sensory loss. The lower part of the leg was involved in 4 cases with an accessory nerve root and in 15 cases without an accessory nerve. Urinary incontinence was detected in six patients and three of them had conjoined nerve root. Cauda equina findings were detected in one case with accessory nerve root whereas in five cases without. Motor and sensory examinations were conducted in all patients preoperatively ${ }^{8}$. In our study, we examined all patients with a preoperative Lasègue test and a femoral nerve crossed straight-leg-raise test.

In lumbar disc herniations, treatment is classified under two headings, namely conservative and surgical methods ${ }^{13,14}$. Various surgical methods are employed in lumbar disc herniations ${ }^{1}$. We opearated all of our patients by using the conventional microdiscectomy method. During this kind of surgery, nerve root abnormalities may be encountered ${ }^{15}$. Some authors separated accessory nerve root abnormalities into three, five or six groups ${ }^{5,6}$. The most commonly used is the Neidre and MacNab classification. Lumbosacral nerve root abnormalities were observed in 46 patients out of a total of 
2123 patients in the study conducted by Posthaccini et al., and these abnormalities were divided into five class$\mathrm{es}^{5}$. According to the Neidre and MacNab classification, nerve root abnormalities were divided into six groups ${ }^{6}$. Berta et al. detected conjoined nerve root abnormalities in four out of 80 patients $^{16}$. In the study conducted by Taghipour et al., conjoined nerve root abnormality was most frequently observed in L4-5 level ${ }^{17}$. In our study, conjoined nerve root abnormality was detected in 22 out of 820 patients and mostly in L5-S1 level with 16 patients.

Although microdiscectomy is the best surgical method, complications at a rate of $2-14 \%$ have been reported. These complications include instability of spinal ligaments and spinal muscles during laminectomy, facet deformation, spinal dural tears and root injuries ${ }^{18,19}$. In a study conducted by Leunge, dural tears were detected in two patients out of a total of 40 patients ${ }^{7}$. In our study, dural injury or dural tear were experienced in 28 patients $(3.41 \%)$ with no accessory nerve root and in 6 patients $(27.27 \%)$ with accessory nerve root. These were treated using appropriate methods. The rate of dural tear or root injury during surgery was found to be higher and more significant in patients with an accessory nerve root.

As a conclusion, during lumbar microdiscectomy operations, accessory nerve roots were most frequently observed at the lower segments including L4-5 and L5-S1 levels, and the dural tears and nerve root injuries were higher than the normal group. Accordingly, we wish to emphasize that during lower segment disc herniation operations, special attention to the accessory nerve root will be useful in preventing dural tears and root injuries.

\section{References}

1. Akbay A, Bozkurt G, Palaoğlu S. Disk hernileri ve spinal dar kanal. In: Akson K, Pamir N, editors. Temel Nöroşirürji. Ankara: Hacettepe yayınları; 2004:277-93.

2. Veresciagina K, Spakauskas B, Ambrozaitis KV. Clinical outcomes of patients with lumbar disc herniation, selected for one-level open-discectomy and microdiscectomy. Eur Spine J 2010;19:1450-8.

3. Blamoutier A. Surgical discectomy for lumbar disc herniation: surgical techniques. Orthop Traumatol Surg Res 2013;99:187-96.
4. Trimba R, Spivak JM, Bendo JA. Conjoined nerve roots of the lumbar spine. Spine J 2012;12:515-24.

5. Postacchini F, Urso S, Ferro L. Lumbosasacral nerve-root anomalies. J Bone Joint Surg Am 1982;64:721-3.

6. Burke SM, Safain MG, Kryzanski J, et al. Nerve root anomalies: implications for transforaminal lumbar interbody fusion surgery and a review of the Neidre and Macnab classification system. Neurosurg Focus 2013;35:9-13.

7. Leung PC. Complications in the first 40 cases of microdiscectomy. J Spinal Disord 1988;1:306-10.

8. Toplamoğlu H. Lumber Disc Hernia. In: Akson K, Pamir N, editörler. Temel nöroşirürji. Ankara: Hacettepe yayınları; 2005:1056-61.

9. Kubaszewski Ł, Nowakowski A, Gasik R, et al. Intraobserver and interobserver reproducibility of the novel transcription method for selection of potential nerve root compression in MRI study in degenerative disease of the lumbar spine. Med Sci Monit 2013;19:216-21.

10. Imaad-ur-Rehman, Hamid RS, Akhtar W, et al. Observer variation in MRI evaluation of patients with suspected lumbar disc herniation and nerve root compression: comparison of neuroradiologist and neurosurgeon's interpretations. J Pak Med Assoc 2012;62:826-9.

11. Raja RA, Khemani VD, Lakhair MA, et al. Discectomy in single level lumbar disc disease. J Ayub Med Coll Abbottabad 2012;24:81-3.

12. Biluts H, Munie T, Abebe M. Review of lumbar disc diseases at Tikur Anbessa Hospital. Ethiop Med J 2012;50:57-65.

13. Deburge A, Bex M, Lassale B, et al. Surgical technic in the treatment of stenosis of the lumbar canal. Acta Orthop Belg 1987;53:412-9.

14. Durakan A, Tatlısumak T. Kemik ve eklem hastalıkları ile ilişkili Nörolojik bozukluklar. In: Bahar SZ, Çoban O, editors. Neurology and General Medicine. Ankara:Güneş Tip Kitapevleri; 2010: 441-8.

15. McCulloch JA, Waddell G. Variation of the lumbosacral myotomes with bony segmental anomalies. J Bone Joint Surg Br 1980;62:475-80.

16. Scuderi GJ, Vaccaro AR, Brusovanik GV, et al. Conjoined lumbar nerve roots: a frequently underappreciated congenital abnormality. J Spinal Disord Tech 2004;17:86-93.

17. Taghipour M, Razmkon A, Hosseini K. Conjoined lumbosacral nerve roots: analysis of cases diagnosed intraoperatively. J Spinal Disord Tech 2009;22:413-6.

18. Proietti L, Scaramuzzo L, Schiro GR, et al. Complications in lumbar spine surgery: A retrospective analysis. Indian J Orthop 2013;47:340-5.

19. Yoshihara H, Yoneoka D. Incidental dural tear in lumbar spinal decompression and discectomy: analysis of a nationwide database. Arch Orthop Trauma Surg 2013;15:20-3. 


\title{
Correlation of Cardiovascular Limitations and Symptoms Profile with the Quality of Life, Anxiety and Depression Scales
}

\author{
Kardiyovasküler Kısıtııık ve Semptomlar Profilinin Yașam Kalitesi, Anksiyete ve Depresyon \\ Skalaları ile Ilișkisi
}

\author{
Derya Özcanlı Atik', Sezgi Çınar ${ }^{2}$ \\ ${ }^{1}$ Kahramanmaraş Sütçü İmam University, School of Health, Nursing Division, Kahramanmaraş; ${ }^{2}$ Marmara University Faculty of \\ Health Sciences, Department of Nursing, Department of Internal Medicine, İstanbul
}

\begin{abstract}
AIM: The aim of our study was to determine the relationship between patients' limitations and symptoms after acute coronary syndromes and quality of life, anxiety and depression levels.

METHODS: The universe of the research consisted of 245 patients who applied to the cardiology clinic of Kahramanmaraș State Hospital and who received treatment. Data were collected by using the Cardiovascular Limitations and Symptoms Profile, and the Quality of Life, Anxiety and Depression Scales. Percentage, mean, Pearson and Spearman correlation analyses were used during data assessment.

RESULTS: The mean of the patients' age was $60.58 \pm 11.81$ years, $68.6 \%$ of the patients were male, and $56.3 \%$ had experienced acute myocardial infarction. The patients experienced moderate level of limitations in physical and social functions (16.64 44.46), minor level of limitations in activities within the home (women: $3.05 \pm 1.41$; men: $3.23 \pm 1.40$ ), and moderate level of concerns (8.65 \pm 2.63$)$. Statistically significant correlations were found between limitations and symptoms, and the parameters of quality of life, anxiety and depression.
\end{abstract}

CONCLUSION: The limitations and symptoms of the patients experienced after acute coronary syndromes are affective on quality of life, anxiety and depression.

Key words: acute coronary syndromes; limitations and symptoms; quality of life; anxiety; depression

\section{ÖZET}

AMAÇ: Çalıșmamızın amacı, akut koroner sendromlar sonrası hastaların kısıtılık ve semptomları ile yașam kalitesi, anksiyete ve depresyon düzeyleri arasında ilișki olup olmadı̆̆ını belirlemektir.

YÖNTEM: Araștırmanın evrenini, Kahmanmaraș Devlet Hastanesi kardiyoloji kliniğine bașvurarak tedavi gören akut koroner sendrom geçirmiș 245 hasta olușturdu. Veriler Kardiyovasküler Kısıtılık ve Semptomlar Profili, Yașam Kalitesi, Anksiyete ve Depresyon Ölçekleri

Derya Özcanlı Atik, Kahramanmaras Üniversitesi Sağllk Yüksekokulu Bahçelievler Kampüsü, Kabramanmaras,,Türkiye Tel.05349701568 Email.deryaatik09@hotmail.com

Geliş Taribi: 22.04.2013 • Kabul Taribi: 13.03.2014 ile toplandı. Verilerin değerlendirilmesinde, yüzdeler, ortalamalar, Pearson ve Spearman korelasyon analizleri kullanıldı.

BULGULAR: Hastaların yaș ortalamasının 60.58 11.81 yıl, çoğunluğunun erkek (\%68.6) ve \%56.3'ünün akut miyokart infarktüsü geçirdiği belirlendi. Hastaların; fiziksel ve sosyal fonksiyonda (16.64 \pm 4.46$)$ orta düzeyde, kadınlara özgü ev içi faaliyetlerinde (3.05 \pm 1.41$)$ ve erkeklere özgü ev içi faaliyetlerinde $(3.23 \pm 1.40)$ hafif düzeyde kısıtılık yașadıkları, kaygı düzeylerinin orta derecede olduğu (8.65 \pm 2.63$)$ belirlendi. Kısıtılık ve semptomlar ile yașam kalitesi, anksiyete ve depresyon parametreleri arasında istatistiksel olarak anlamlı korelasyonlar bulundu.

SONUÇ: Akut koroner sendromlar sonrası hastaların yașadıkları kısıtılık ve semptomlar, yașam kalitesi, anksiyete ve depresyon düzeyleri üzerine etkilidir.

Anahtar kelimeler: akut koroner sendromlar; kısıtıllık ve semptomlar; yașam kalitesi; anksiyete; depresyon

\section{Introduction}

Improvements of the outcomes of coronary artery diseases (CAD), thus acute coronary syndromes (ACSs), led to higher survival rates and longer life expectancy. Increase in lifetime necessitates patients' compliance to the disease state and the patient has to face with new onset physical, psychological, social and economic problems.

Post-ACS symptoms and complications limit patients' physical, emotional and social functions, and decrease their sense of satisfaction and quality of life ${ }^{1}$. After myocardial infarction (MI) individuals experience anxiety, fatigue, irritability, impairment of concentration, and sleep problems. Patients' quality of life is reduced in association with loss of personal control, inability to perform self care activities, and fear of death. Quality of life is negatively affected by factors such as 
difficulty in physical activities including walking, running, climbing stairs, stooping and straightening up; functional dependency, various limitations, and needing help in daily life activities ${ }^{2}$. Individuals with ACS, in the first 4-8 week period in which they are expected to resume their normal life after MI, experience difficulties in returning to their normal life and face with social traumas like job loss, divorce and job switches. During post-ACS period, both patients and their families deal with a high level of stress ${ }^{1,3}$.

ACSs hold an important place among CADs and their prevalence increases worldwide. ACSs are among the most important causes of mortality and morbidity, however advancements achieved in drug therapies and interventions have increased patients' life-span. Despite modern treatment options; recurrent MI, rehospitalization and mortality rates are very high in patients with $\mathrm{ACS}^{4}$. ACSs pose serious threats to human life and can cause several complications during and after the acute phase. These conditions result in some limitations and symptoms, and adversely affect the quality of life.

Nurses are among the professions responsible from protecting and improving patients' quality of life. While fulfilling their responsibilities, they should determine patients' quality of life and the factors affecting quality of life. In order to increase patients' quality of life after ACS, their medical, physical, psychological and social requirements should be managed by using an effective treatment and rehabilitation program.

This study was conducted to determine, if there was a relationship between patients' limitations and symptoms after acute coronary syndromes and their quality of life, anxiety and depression levels.

\section{Methods}

\section{Study Design}

This research was conducted descriptively by using the "Cardiovascular Limitations and Symptoms ProfileCLASP" to determine the relationship between patients' limitations and symptoms after acute coronary syndromes and their quality of life, anxiety and depression levels.

\section{Setting and Samples}

The research was conducted in the cardiology clinic of Kahramanmaraş State Hospital.
The universe of the research consisted of the patients applying to the cardiology clinic between April 2011 and September 2011 with acute coronary syndrome.

Power analysis was performed with the following formula to determine sample size:

$\mathrm{n}=\mathrm{N} \mathrm{t}^{2} \mathrm{pq} / \mathrm{d}^{2}(\mathrm{~N}-1)+\mathrm{t}^{2} \mathrm{pq}$

Based on the fact that 21000 patients applied to the cardiology clinic between 2010 and 2011, and 20\% of these patients had experienced acute coronary syndrome; the sample size was calculated with the formula below, accepting that the results would be within $95 \%$ confidence interval and would include $d=0.05$ sampling error:

$\mathrm{n}=(21000)(1.96)^{2}(0.20 \times 0.80) /(0.05)^{2}(21000-1)$

$+(1.96)^{2}(0.20 \times 0.80)=243.029$

At the end of the power analysis, sample size was determined to be 243 and the research sample consisted of 245 patients with acute coronary syndrome.

Inclusion criteria were as follows:

1. History of myocardial infarction, unstable angina pectoris, and percutaneous coronary intervention secondary to acute coronary syndromes more than one month duration.

2. Patients aged 18 years or older without communication problems.

3. Willingness to participate and answer all questions in Turkish.

\section{Ethical Considerations}

The research was conducted in compliance with scientific principles as well as with the ethical principles of the Declaration of Helsinki. Accordingly, informed consent, confidentiality, equity, primum non nocere principles were taken into account. In the adaptation of the Cardiovascular Limitations and Symptoms Profile-CLASP into Turkish, necessary permission was obtained from those who developed the original scale.

Written permission for conducting the research was obtained from the relevant committee (Governorship of Kahramanmaraş, Directorate of Health, B104ISM4460001/314) and approval was received from the Ethics Committee (Marmara University, Institute of Medical Sciences, Clinical Research Committee for Pre-Assessment). The patients who would participate in the research were informed about 
the aim, design and benefits of the study, and the patients who accepted to participate in the study were asked to sign the informed consent form.

\section{Measurements}

Data were collected by face-to-face interview, using the Patient Description Form, Cardiovascular Limitations and Symptoms Profile, SF-36 Quality of Life Scale, and Hospital Anxiety and Depression Scale.

Patient Description Form: It was prepared to determine the socio-demographic characteristics (gender, age, height, weight, education, marital status, occupation, work status, people they lived with) and disease-related characteristics (clinical diagnosis, cholesterol values, duration of acute coronary disease, regular control visits, regular medication use, dietary compliance).

Cardiovascular Limitations and Symptoms Profile-CLASP: The scale was developed by Lewin et al. in $2002^{5}$, and its validity and reliability in Turkish was established by Özcanlı Atik 6 .

SF-36 2uality of Life Scale: Short Form 36, which is a generic scale and which offers a wide range measurement for quality of life, was developed in $1992^{7}$. The first reliability and validity study of SF-36 in Turkey was conducted in 1995 by Pinar $^{8}$.

Hospital Anxiety and Depression Scale (HADS): The Hospital Anxiety and Depression Scale was developed by Zigmond and Snaith ${ }^{9}$ to screen anxiety and depression in individuals with a physical disease. The validity and reliability study of this scale in Turkish was performed by Aydemir ${ }^{10}$.

\section{Research hypotheses:}

1. Severity of angina is related with anxiety and depression or Quality of Life (QoL),

2. Severity of shortness of breath is related with anxiety and depression or QoL,

3. Severity of ankle swelling is related with anxiety and depression or QoL,

4. Severity of tiredness is related with anxiety and depression or QoL,

5. Severity of physical and social dysfunctions is related with anxiety and depression or QoL,

6. Severity of disorders of men's activities within home is related with anxiety and depression or QoL,
7. Severity of disorders of women's activities within home is related with anxiety and depression or QoL,

8. Severity of concerns and worries is related with anxiety and depression or QoL,

9. Gender is related with anxiety and depression or QoL.

\section{Data Analysis}

SPSS (Statistical Package for Social Science) version 16.0 program was used for collecting and assessing the research data. Percentage, mean, Pearson and Spearman correlation analyses were used in statistical assessment.

\section{Results}

\section{Socio-Demographic Variables of the Participants}

Table 1 summarizes the socio-demographic findings of the participants of the study. The mean age of all participants, men and women were $60.58 \pm 11.81$, $63.18 \pm 12.25$ and $59.39 \pm 11.44$ years, respectively.

\section{Clinical Characteristics}

The clinical characteristics (Cardiovascular Limitations and Symptoms Profile, SF-36 2uality of Life Scale and Hospital Anxiety and Depression Scale) of the participating patients were summarized in Table 2.

Table 3 summarizes the mean scores of the patients' limitations and symptoms. The results of quality of life, anxiety and depression scales were also summarized in Table 3.

The frequency of angina positively correlated with the scores of anxiety and depression symptoms and negatively correlated with the quality of life scores $(p<0.05)$.

Shortness of breath diminished gender functioning $(p<0.05)$ and quality of life $(p<0.01)$, and it increased anxiety and depression symptoms $(\mathrm{p}<0.01)$.

Ankle swelling reduced gender functioning and quality of life $(p<0.01)$ and it increased anxiety and depression symptoms $(\mathrm{p}<0.01)$.

Tiredness worsened quality of life $(p<0.01)$ and it increased anxiety and depression symptoms $(\mathrm{p}<0.01)$.

Lower physical and social functioning scores were correlated positively with decreased gender functions and quality of life $(\mathrm{p}<0.01)$ and negatively with anxiety and depression scores $(\mathrm{p}<0.01)$. 
Table 1. Socio-demographics of the participants $(n=245)$

\begin{tabular}{|c|c|c|c|}
\hline Variable & $\mathrm{n}(\%)$ & Variable & $\mathrm{n}(\%)$ \\
\hline Age (years) & & People Living With & \\
\hline $18-29$ & $1(0.4)$ & Alone & $21(8.6)$ \\
\hline $30-49$ & 38 (15.5) & Spouse & $72(29.4)$ \\
\hline $50-69$ & $143(58.4)$ & Spouse and children & $130(53.1)$ \\
\hline$\geq 70$ & $63(25.7)$ & Others & $22(9)$ \\
\hline Gender & & Social Security & \\
\hline Female & 77 (31.4) & Yes & $230(93.9)$ \\
\hline Male & $168(68.6)$ & No & $15(6.1)$ \\
\hline Education & & Profession & \\
\hline Illiterate & $60(24.5)$ & Housewife & $67(27.3)$ \\
\hline Literate & 38 (15.5) & Workman & $25(10.2)$ \\
\hline Primary education & $105(42.9)$ & Pensioner & $52(21.2)$ \\
\hline High school & $36(14.7)$ & Civil servant & $10(4.1)$ \\
\hline \multirow[t]{2}{*}{ University } & $6(2.4)$ & Free & $61(24.9)$ \\
\hline & & Others & $30(12.2)$ \\
\hline Marital Status & & Working status & \\
\hline Married & $220(89.8)$ & Unemployed & $164(66.9)$ \\
\hline Single & $5(2)$ & Full-time job & $40(16.3)$ \\
\hline Widowed & $20(8.2)$ & Part-time job & $41(16.7)$ \\
\hline
\end{tabular}

Table 2. Clinical characteristics of the participants $(n=245)$

\begin{tabular}{|c|c|c|c|}
\hline Characteristics & $\mathrm{n}(\%)$ & Characteristics & $\mathrm{n}(\%)$ \\
\hline Diagnosis & & Number of hospital admissions & \\
\hline USAP & $107(43.7)$ & 1 & $71(29)$ \\
\hline AMI & $138(56.3)$ & $\geq 2$ & $174(71)$ \\
\hline Duration of ACS & & On medication & \\
\hline $1-6$ months & $120(49)$ & Regular & $108(44.1)$ \\
\hline 6 months -1 year & $38(15.5)$ & Mostly & $46(18.8)$ \\
\hline $1-2$ years & $24(9.8)$ & Occasionally & $66(26.9)$ \\
\hline $2-5$ year & $19(7.8)$ & Never & $25(10.2)$ \\
\hline$\geq 5$ years & $44(18)$ & & \\
\hline Compliance with the follow up visits & & Compliance with diet & \\
\hline Regularly & $68(27.8)$ & Regularly & $58(23.7)$ \\
\hline Mostly & $49(20)$ & Mostly & $50(20.4)$ \\
\hline Occasionally & $81(33.1)$ & Occasionally & $78(31.8)$ \\
\hline Never & 47 (19.2) & Never & $59(24.1)$ \\
\hline Having risk factors for ACS & & Having complications & \\
\hline Yes & $236(96.3)$ & Yes & $145(59.2)$ \\
\hline No & $9(3.7)$ & No & $100(40.8)$ \\
\hline \multicolumn{4}{|l|}{ Lipid levels } \\
\hline $\mathrm{LDL}(\mathrm{mg} / \mathrm{dl})$ & $125.07 \pm 35.54$ & Kolesterol & $169.13 \pm 41.63$ \\
\hline $\mathrm{HDL}(\mathrm{mg} / \mathrm{dl})$ & $37.17 \pm 10.35$ & & \\
\hline
\end{tabular}


Table 3. The summary of the data gathered by using the study forms. Limitations, symptoms, quality of life, anxiety and depression scores of 245 participants were expressed with mean \pm standard deviation (SD) and minimum - maximum (min - max) values

\begin{tabular}{lcc}
\hline & (mean \pm SD) & $($ min - max $)$ \\
\hline Cardiovascular Limitations and Symptoms Profile Limitations and Symptoms & & $0-16$ \\
Angina & $7.48 \pm 4.82$ & $0-14$ \\
Shortness of Breath & $6.69 \pm 4.93$ & $0-10$ \\
Ankle Swelling & $1.86 \pm 3.16$ & $0-9$ \\
Tiredness & $6.08 \pm 2.96$ & $7-23$ \\
Physical and Social Functions & $16.64 \pm 4.46$ & $2-6$ \\
Women's activities within the home & $3.05 \pm 1.41$ & $2-6$ \\
Men's activities within the home & $3.23 \pm 1.40$ & $3-12$ \\
Concerns and Worries & $8.65 \pm 2.63$ & $0-12$ \\
Gender & $4.09 \pm 4.33$ & $0-100$ \\
SF-36 Quality of Life Scale & & $0-100$ \\
Physical Function & $49.92 \pm 29.55$ & $0-100$ \\
Physical Role & $34.33 \pm 38.18$ & $0-100$ \\
Emotional Role & $37.15 \pm 37.23$ & $0-100$ \\
Social Function & $55.42 \pm 31.79$ & $0-90$ \\
Mental Health & $48.84 \pm 21.24$ & $0-100$ \\
Vitality & $29.64 \pm 22.23$ & $0-92$ \\
Pain & $42.46 \pm 27.05$ & $0-21$ \\
General Health & $40.69 \pm 23.76$ & \\
Hospital Anxiety and Depression Scale & & \\
Anxiety & $10.43 \pm 5.18$ & $11.31 \pm 5.15$ \\
Depression & & \\
\hline
\end{tabular}

The scores of men's activities within the home correlated negatively with angina $(p<0.01)$, shortness of breath $(\mathrm{p}<0.05)$, tiredness $(\mathrm{p}<0.01)$, the quality of life $(\mathrm{p}<0.01)$, and positively with the scores of physical and social functioning $(\mathrm{p}<0.01)$, concerns and worries $(\mathrm{p}<0.01)$, anxiety $(\mathrm{p}<0.01)$.

The scores of women's activities within the home correlated negatively with the scores of anxiety and depression symptoms $(\mathrm{p}<0.01)$ and the quality of life $(\mathrm{p}<0.01)$.

The concerns and worries correlated positively with anxiety and depression symptoms $(\mathrm{p}<0.01)$ and negatively with quality of life $(\mathrm{p}<0.01)$.

Gender functioning correlated negatively with shortness of breath, ankle swelling, and anxiety $(\mathrm{p}<0.05)$; and it correlated positively with mental health, physical functioning, social functioning, and general health perception $(\mathrm{p}<0.05)$.

\section{Discussion}

Physical, psychological and occupational limitations and symptoms after acute coronary syndrome can impair individuals' quality of life. In the present study, the general evaluation of the limitation and symptom levels of the patients revealed that patients experienced angina and shortness of breath at a minor level, and tiredness at a moderate level. It was also determined that patients experienced limitations in physical and social functions at a moderate level, women's and men's activities within the home at a minor level, concerns and worries at a moderate level, and that their mean scores for gender were at a normal level and they did not experience any limitations in this sub-domain. Ankle swelling complains were quite low, indicating that ankle swelling symptoms were not at a significant level among the patients (Table 3 ).

The Quality of Life SF-36 score averages are evaluated within the range from 0 to 100 , where " 0 " indicates the worst and "100" indicates the best health condition ${ }^{11}$. According to the results obtained from the study, the patients experienced concerns and worries generally at a moderate level, which affected their emotional role and mental health score averages; they experienced angina and shortness of breath at a minor level and tiredness at a moderate level, which affected their physical function, physical role, liveliness/tiredness, pain and 
perceived general health, and therefore did not cause a significant increase in their score averages.

The participants experienced limitations in physical and social functions at a moderate level. The activities within the home were affected a little bit. Kurcer et al., in their initial assessment of coronary artery patients, found SF-36 mean scores $38.0 \pm 3.3$ for physical function, $22.5 \pm 4.2$ for physical role, $26.6 \pm 1.9$ for emotional role, $47.2 \pm 2.6$ for mental health, $41.2 \pm 14.7$ for social function, $50.0 \pm 15.9$ for perceived general health, $38.0 \pm 10.1$ for liveliness/tiredness, and 32.0 \pm 10.4 for pain ${ }^{12}$.

In Turkey the cutoff score has been found 10/11 for the anxiety sub-scale and 7/8 for the depression sub-scale. Accordingly, the scores above these values were evaluated as risky scores ${ }^{11}$. In our study, anxiety levels of $51.2 \%$ and depression levels of $73.2 \%$ of the patients were determined above the cutoff scores (Table 3 ).

According to our study results, the moderate level of worries and concerns and other limitations and symptoms experienced by the patients may be considered as high risks for depression and anxiety. In the study conducted by Canlı et al., serious anxiety was reported in all patients (100\%) included in the research, and serious depression was reported in $34 \%$ of the patients ${ }^{13}$. On the other hand, in a different study carried out with MI patients, anxiety and depression levels were determined to be low ${ }^{14}$.

Correlation analysis of the study variables did not show significant correlation between gender and physical role, emotional role, liveliness/tiredness, pain, depression, angina, tiredness, women's and men's activities within the home and concerns-worries. The findings support the validity of the CLASP scale in measuring the physical, social and psychological health of ACS patients.

Lewin et al. studied the validity and reliability of CLASP and determined significant correlations between the relevant sections of the disease effect profile and CLASP, between the sleep problems scale and the tiredness sub-domain of CLASP, and between the worries sub-domain of CLASP and anxiety and depression ${ }^{5}$. In the study carried out by Lopez et al., significant correlations were found between CLASP and the relevant sections of SF-36 and HADS ${ }^{15}$.

In line with these results, it may be suggested that nurses should evaluate ACS patients' limitations and symptoms and their quality of life at regular intervals. Following the evaluation, treatment and applications for improving quality of life should be planned and initiated. ACS patients have limitations and symptoms that lower their life quality and make them prone to anxiety and depression.

\section{References}

1. Eski S. Determination of Quality of Life in Individuals with Myocardial Infarction. Ankara: Hacettepe University Institute of Health Sciences; 1999.

2. Akyol AD. Importance in terms of the quality of life of nursing. Journal of Ege University School of Nursing 1993;9:71-5.

3. Kuzu N. Myocardial infarction effect on sexual function and sexual counseling role of the nurse. Hacettepe University School of Nursing Journal 1999;3:19-22.

4. Non-ST-Segment Elevation Acute Coronary Syndromes of the European Society of Cardiology Diagnosis and Treatment Task Force. ST-Segment Elevation Acute Coronary Syndromes Diagnosis and Treatment Guide. Arch Turk Soc Cardiol 2008;36:90-152.

5. Lewin RJ, Thompson DR, Martin CR, et al. Validation of the Cardiovascular Limitations and Symptoms Profile (CLASP) in chronic stable angina. J Cardiopulm Rehabil 2002;22:184-91.

6. Ozcanli Atik D. The Evaluation of Limitations and Symptoms in After Acute Coronary Syndromes. İstanbul: Marmara University Institute of Health Sciences; 2012.

7. Ware JE, Sherbourne CD. The MOS 36-item short-form health survey (SF-36). I. Conceptual framework and item selection. Med Care 1992;30:473-83.

8. Pinar R. New concept in health research: Quality of life; validity and reliability of a quality of life measurement scale. Nursing Bulletin 1995;9:85-95.

9. Zigmond AS, Snaith PR. The hospital anxiety and depression scale. Acta Psychiatr Scand 1983;67:361-70.

10. Aydemir O. Reliability and Validity of the Turkish Version of the Hospital Anxiety and Depression Scale Study. Turkish Journal of Psychiatry 1997;8:280-7.

11. Kocyigit H, Aydemir O, Fisek G, et al. Short Form-36's reliability and validity of the Turkish version. Medication and Treatment 1999;12:102-6.

12. Kurcer MA, Ozbay A. Coronary artery disease, the impact of lifestyle education and counseling on quality of life. Anatolian Journal of Cardiology 2011;11:107-13.

13. Canli Ozer Z, Senuzun F, Tokem Y. Examination of anxiety and depression in patients with myocardial infarction. Arch Turk Soc Cardiol 2009;37):557-62.

14. Cam O, Nehir S. Psychosocial adaptation of patients with myocardial infarction examination of the relationship between levels of depression and anxiety. Journal of Ege University School of Nursing 2011;27:47-59.

15. Lopez V, Chair SY, Thompson DR, et al. A psychometric evaluation of the Chinese version of the Cardiovascular Limitations and Symptoms Profile in patients with coronary heart disease. J Clin Nurs 2008;17:2327-34. 


\title{
Parotid Kitlelerinin Değerlendirilmesinde İnce İğne Aspirasyon Biyopsisi ile Histopatolojinin Karșılaștırılması
}

\section{Comparison of Fine Needle Aspiration Biopsy and Histopathology in the Evaluation of Parotid Masses}

\author{
Ali Osman Özbey', Fatih Bora', Ahmet Kutluhan'2, Mahmut Duymuș³, Kazım Bozdemir ${ }^{4}$ \\ ${ }^{1}$ Kafkas Üniversitesi, Tip Fakültesi, Kulak-Burun-Boğaz Anabilim Dal, Kars; ${ }^{2}$ Medicalpark Hastaneleri, Kulak-Burun-Boğaz Kliniği, İstanbul; \\ ${ }^{3}$ Kafkas Üniversitesi, T⿰⿱中⿰㇀丶下 Fakültesi, Radyoloji Anabilim Dal, Kars; ${ }^{4}$ Atatürk Eğitim ve Araş̧trma Hastanesi, Kulak-Burun-Boğaz Kliniği, Ankara
}

\begin{abstract}
AIM: To determine the diagnostic value of fine needle aspiration biopsy (FNAB) of parotid masses in the basis of postoperative histopathological results.

METHODS: The study was conducted in Ankara Atatürk Training and Research Hospital first Otolaryngology clinics. Thirty-three parotidectomy specimens and FNAB results were included.

RESULTS: FNAB sensitivity, specificity, positive predictive value (PPV), negative predictive value (NPV) were calculated as $4 / 5$ (80\%), 27/28 (96.4\%), 4/5 (80\%), 27/28 (96.4\%), 31/33 (93.9\%), respectively in the basis of postoperative benign and malign pathology results.

CONCLUSION: FNAB is an easy, quick, highly specific and sensitive, cheap and reliable diagnostic technique for parotis masses. In our study, the high sensitivity and specificity values were correlated with literature data.
\end{abstract}

Key words: biopsy, fine needle; parotid neoplasms; predictive value of tests; sensitivity and specificity

\section{ÖZET}

AMAÇ: Parotis kitlelerinde postoperatif histopatolojik sonuçlar referans alınarak ince iğne aspirasyon biyopsisinin (iiAB) tanısal değerini belirlemek.

YÖNTEM: Çalıșmaya Ankara Atatürk Eğitim ve Araștırma Hastanesi 1. Kulak-Burun-Boğaz kliniği tarafından yapılan 33 parotidektomi spesimeninin histopatolojik tanısı ve ilAB sonuçları dahil edildi.

BULGULAR: Postoperatif patoloji sonuçları referans alındığında benign ve malign ayrımında iïAB nin duyarlıık, özgüllük, doğru tahmin değeri (PPV-pozitif prediktif value), yanlıș tahmin değeri (NPVnegatif prediktif value) ve yararlılık oranı sırası ile 4/5 (\%80), 27/28 (\%96,4), 4/5 (\%80), 27/28 (\%96,4), 31/33 (\%93,9) olarak hesapland..

Dr. Ali Osman Özbey, Siverek Devlet Hastanesi KBB Kliniği, Şanliurfa, Türkiye, Tel.05363866680Email.aliosmanozbey@hotmail.com

Geliş Taribi: 31.10.2013 • Kabul Taribi: 27.02.2014
SONUÇ: IiAB parotis kitlelerinde kolay uygulanan, çabuk ve güvenilir sonuç veren, duyarlılık ve özgüllügü yüksek, ucuz ve risksiz erken tanı yöntemidir. Çalıșmamızda bulunan yüksek duyarlılık ve özgüllük değerleri literatür verileri ile korelasyon göstermektedir.

Anahtar kelimeler: biyopsi, ince iğne; parotis neoplazileri; testlerin tahmin değerleri; duyarlılık ve özgüllük

\section{Giriș}

Tükürük bezi tümörleri, tüm baş boyun tümörlerinin \%3-12'sini ve tüm vücut tümörlerinin ise \%2-3'ünü oluşturmaktadır. Bu tümörlerin \%80’i parotis bezinden köken almaktadır ${ }^{1}$. Parotis bezi tümörlerinin yaklaşık \%80'i benign, \%20'si ise malign yapıdadır ${ }^{1-3}$. Parotis tümörlerinde preoperatif değerlendirme, parotise komşu yapılardan köken alan lezyonların ayrilmasında ve lezyonlara yönelik farklı tedavi yaklaşımları olması nedeniyle oldukça değerlidir. Doğru değerlendirme ile medikal tedavi, klinik takip ya da cerrahi tedavi seçeneklerinden birine karar verilmesi yanı sıra, preoperatif değerlendirme bezin fasial sinir ile yakın komşuluğu nedeniyle cerrahi planlama ve gereksiz cerrahiyi engellemek açısından da önemlidir ${ }^{4,5}$. Preoperatif patolojinin bilinmesi cerrahi planlamada da kolaylık sağlamaktadır. Operasyon öncesi değerlendirme aşamasında ince iğne aspirasyon biyopsisi (İIAB) sıklıkla kullanılmaktadır.

$\mathrm{Bu}$ çalı̧̧mada, parotis bezi kitlelerinin histopatolojik tanıları ile operasyon öncesi yapılan İİAB bulguları karşılaştırılarak İIAB’nin duyarlılık, özgüllük, pozitif tahmin değeri (PPV) ve negatif tahmin değerlerinin $(\mathrm{NPV})$ ve etkinliğinin belirlenmesi amaçlandı. 


\section{Yöntem}

Çalışmanın evrenini oluşturmak için Ankara Atatürk Eğitim ve Araştırma Hastanesi 1. KBB Kliniğinde Ağustos 2004 ile Haziran 2011 tarihleri arasinda parotidektomi operasyonu geçirmiş hastaların dosyaları retrospektif olarak tarandi. İncelenen süre içerisinde ameliyat olan 52 hastadan 33 'ü çalışma kriterlerine uyum sağlamaları ve verilerinin tespit edilebilmeleri sebebiyle çalışmaya kabul edildi. Çalışma öncesi ilgili kurumdan izin alındı ve Helsinki bildirgesine uygun olarak katılımcıların öznelliğine saygı duyuldu.

Ameliyat verileri incelendiğinde hastalara endikasyonuna göre süperfisiyal parotidektomi, total parotidektomi veya total parotidektomi ve boyun diseksiyonu operasyonları yapıldığ 1 tespit edildi. Hastaların ameliyat öncesi yapılan İ̇AB sonuçları ile parotidektomi spesimeninin histopatolojik bulgularının uyumluluğu karşılaştırıldı.

İİAB'leri Ankara Atatürk Eğitim ve Araştırma Hastanesi 1 . KBB Kliniğince yapıld. Tüm biyopsiler için 10 cc'lik enjektör ve 21 Gauge yeşil uçlu iğne kullanıldı. Preparatlar havada kurutma işleminin ardından $\% 10$ 'luk formaldehitin içerisinde patoloji laboratuvar1na gönderildi. Patoloji değerlendirmeleri aynı hastanenin patoloji kliniği tarafından değerlendirildi.

Postoperatif patoloji sonuçları referans alınarak preoperatif ince iğne aspirasyon sitolojisinin tanısal değeri araştırıldı. Postoperatif histopatolojik sonuçlar ve preoperatif İIAB sonuçları benign ve malign olmak üzere iki gruba ayrıldı. İnflamatuar ve kistik lezyonlar da benign lezyonlar içerisinde değerlendirildi.

\section{iiAB tekniği}

İ̇AB oldukça basit, az sayıda ekipman gerektiren ve poliklinik şartlarında kolayca gerçekleştirilebilen bir işlemdir. Kitlelerin üzerindeki deri temizlenir. Lokal anesteziye genellikle gerek duyulmaz. Aspirasyon için 21-27 gauge'luk iğneler, 10-20 ml'lik bir kullanımlık şırınga ve eğer varsa metal şırınga tutucu gerekir. Kitle oynamaması için diğer elimizin ikinci ve üçüncü parmakları arasında sabitlenir ve dik açı ile iğne kitlenin içine sokulur. İğne kitlenin içinde iken piston geri çekilerek negatif basinç oluşturulur. İğne kitle içinde sağa sola açı değiştirmeden ileri geri küçük hareketlerle oynatılır. Ĭğne çıkarıldıktan sonra enjektörün ucu çıkarılıp şırınga hava ile doldurulur. Uç tekrar takılıp önceden temizlenmiş ve hazırlanmış lamların üzerine püskürtülür. Lam üzerindeki materyalin başka bir lam yardımı ile ince bir şekilde yayılması sağlanır. Havada kurutularak ya da alkolde fiksasyondan sonra uygun boyama metodları ile boyanarak incelenir. Kistik olan lezyonlar da kist içeriği aspire edilerek laboratuara incelenmek üzere gönderilmelidir. Kistik ve solid komponentleri olan tümörlerde ise kist içeriği aspire edildikten sonra başka bir enjektörle solid alandan aspirasyon tekrarlanmalıdır. Bazen de küçük doku agregatları aspire edilmiş olabilir. Bu da hücre bloğu hazırlamaya imkan verir'. Çalışmada yer alan bütün hastaların İİAB’si yukarıda tarif edilen teknikle elde edilmişti.

İstatistiksel analizler parotis bezi kitlelerinde İİAB'nin maligniteyi tanıyabilme kapasitesini ölçmek için yapıld. Postoperatif histo-patolojik inceleme gold standart olarak kabul edildi. İstatistik değerlendirmede SPSS (Statistical Package for Social Sciences) istatistik programının 17.0 sürümünden yararlanıldı. Verilerin analizi için tanımlayıcı analizler kullanıldı. Anlamlılık değeri olarak $\mathrm{p}<0,05$ alındı. Sürekli değişkenler ortala$\mathrm{ma} \pm$ standart sapma değerleri, kategorik değişkenler ortanca değerleri ile gösterildiler.

\section{Bulgular}

Parotiste kitle nedeniyle başvuran ve parotidektomi operasyonu olup İIAB sonucuna ulaşılan toplam 33 hasta değerlendirmeye alındı. Hastaların 17'si $(\% 51,5)$ erkek, 16 'sı $(\% 48,5)$ kadındı. Yaş ortalaması $47,24 \pm 13,43$ olup en genç hasta 23 yaşında, en yaşlı hasta 78 yaşındaydı.

Hastaların postoperatif sonuçları ve İİAB tanıları benign ve malign olmak üzere iki alt gruba ayrıldı. Patoloji sonucu inflamatuar ve kistik olarak raporlanan lezyonlarda benign kategorisi içerisine alındı.

Parotis bezi tümörlerinin değerlendirilmesinde preoperatif İIAB ve postoperatif histopatolojik inceleme bulgularının karşılaştırılması Tablo 1'de özetlenmiştir.

Postoperatif patoloji sonucu ve IIIAB patoloji sonucu benign ve malign olarak uyumsuz gelen iki hastanın patoloji raporları şu şekilde idi. Postoperatif patolojik tanısı adenoid kistik karsinom gelen bir hastanin İİAB sonucu pleomorfik adenom, postoperatif patolojik tanısı pleomorfik adenom olarak gelen bir hastanın IİAB sonucu da düşük dereceli mukoepidermoid karsinom olarak raporlanmıştır.

Elde edilen bulguları ile altın standart test olarak kabul edilen postoperatif histo-patolojik inceleme bulgularıyla preoperatif İİAB bulguları karşılaştırıldı (Tablo 2). Benign ve malign ayrımında İİAB’nin duyarlılık, 
Tablo 1. Parotis bezi tümörlerinin değerlendirilmesinde preoperatif Ince Iğne Aspirasyon Biyopsisi (ïAB) ve postoperatif histopatolojik inceleme bulgularının karșilaștırıması

\begin{tabular}{|c|c|c|c|}
\hline & & İ̈AB'de sıklık & Histopatolojik incelemede sıklık \\
\hline & Tanı & $\mathrm{N}(\%)$ & $\mathrm{N}(\%)$ \\
\hline \multirow[t]{10}{*}{ Benign $(\% 84,8)$} & Pleomorfik adenom & $15(\% 53,6)$ & $15(\% 53,6)$ \\
\hline & Warthin tümörü & $6(\% 21,4)$ & $9(\% 32,1)$ \\
\hline & Yoğun nötrofil, lenfositler (apse) & $2(\% 7,1)$ & 0 \\
\hline & Onkositik hücreli neoplazm & $2(\% 7,1)$ & $1(\% 3,6)$ \\
\hline & İnflamatuar kist & $1(\% 3,6)$ & 0 \\
\hline & Benign sitoloji & $1(\% 3,6)$ & 0 \\
\hline & Fibroadipöz doku & $1(\% 3,6)$ & $1(\% 3,6)$ \\
\hline & Benign Lenfoepitelyal Kist & 0 & $1(\% 3,6)$ \\
\hline & Tbc lenfadenit & 0 & $1(\% 3,6)$ \\
\hline & Toplam & $28(\% 100)$ & $28(\% 100)$ \\
\hline \multirow[t]{9}{*}{ Malign $(\% 15,2)$} & Mukoepidermoid karsinom & $1(\% 20)$ & \\
\hline & Malign epitelyal tm & $1(\% 20)$ & \\
\hline & Asinik hücreli karsinom & $1(\% 20)$ & \\
\hline & Adenoid kistik karsinom & $1(\% 20)$ & $2(\% 40)$ \\
\hline & İndiferansiye karsinom & $1(\% 20)$ & \\
\hline & Malign mikst tm & 0 & $1(\% 20)$ \\
\hline & Adeno Skuamöz karsinom & 0 & $1(\% 20)$ \\
\hline & Asinik hücreli karsinom & 0 & $1(\% 20)$ \\
\hline & Toplam & $5(\% 100)$ & $5(\% 100)$ \\
\hline
\end{tabular}

Tablo 2. Parotis bezi tümörlerinin benign malign ayııımında preoperatif İnce iğne Aspirasyon Biyopsisi (ïAB) ve postoperatif histopatolojik inceleme bulgularının karșlaștırılması

\begin{tabular}{llccc}
\hline & & \multicolumn{2}{c}{ Postoperatif histo-patolojik inceleme } & Toplam \\
\hline & & Malign & Benign & 5 \\
İ̈B & Malign & 4 & 1 & 28 \\
& Benign & 1 & 27 & 28 \\
& Toplam & 5 & 28 & 33 \\
\hline
\end{tabular}

özgüllük, doğru tahmin değeri (PPV-pozitif prediktif value), yanlış tahmin değeri (NPV-negatif prediktif value) ve yararlilık oranı sirası ile $4 / 5$ (\%80), $27 / 28$ (\%96,4), 4/5 (\%80), 27/28 (\%96,4), 31/33 (\%93,9) olarak hesapland.

\section{Tartıșma}

İ̇AB parotis kitlelerin preoperatif değerlendirilmelerinde; benign ve malign ayırımı açısından yüksek duyarlılık ve seçiciliğe sahip gibi görünmektedir.

Hekimler İİAB esnasında tümör ekimi ve rekürrens geliştirme riskini azaltmak için İIAB'den kaçınmaktadır. Enzgel ve arkadaşları, pleomorfik adenomlu 157 hastada operasyon öncesi İIAB uyguladıktan sonra 10 yll izlemişler ve bu süre boyunca aspirasyon hattında tümörün ortaya çıkmadığını bildirmişlerdir ${ }^{6,7}$. Bizim serimizdeki hastaların takibinde de tümör ekimine rastlanmadı.

Tükürük bezlerindeki İİAB nin yeterliliği ile ilgili olarak birçok çalışma yapılmıştır. Cohen ve arkadaşları ile Layfield ve arkadaşlarına göre tükürük bezlerinde İIAB’nin doğruluk oranı en az frozen tanıdaki doğruluk oranı kadar yeterli olarak bulunmuştur. Tanıdaki hataların çoğunluğu selüler pleomorfik adenomlar, mukoepidermoid karsinomlar ve lenfomalardir ${ }^{6,8,9}$. Çalışmamızdaki İ́AB sonucu düşük dereceli mukoepidermoid karsinom olarak raporlanan bir hastanın postoperatif patolojik tanısı pleomorfik adenom, IİAB 
sonucu plemorfik adenom olarak raporlanan bir diğer hastanın postoperatif patolojik tanısı da adenoid kistik karsinom olarak raporland.

Çalı̧smamıza dahil olan 33 hastanın İİAB sonuçlarına göre bulunan duyarlılık $(\% 80)$ ve özgüllük $(\% 96,4)$ değerleri literatür ile uygunluk göstermektedir. Mohammed ve arkadaşları, 189 hastanın İ̇AB sonuçlarına göre duyarlılık ve özgüllügüü \%60 ve $\% 96$, Atula ve arkadaşları, 204 serilik çalışmada \%52 ve \%94, Seethala ve arkadaşları, 208 serilik çalışmada $\% 86$ ve $\% 91$ olarak bulmuşlardır ${ }^{10-12}$.

Çalışmamızdaki en sık görülen benign tümör $15 / 33$ $(\% 53,6)$ oranı ile pleomorfik adenom, en sık görülen malign tümör ise $2 / 33(\% 6,1)$ adenoid kistik karsinomdu. Literatürde en sık görülen malign tümör mukoepidermoid karsinomdur ${ }^{13,14}$. Alice Jafari ve arkadaşlarının yaptığı çalışmada en sık benign tümör \%53,6 oranı ile pleomorfik adenom, en sık malign tümör ise $\% 4,5$ oranı ile adenokarsinom olarak tanımlanmışt ${ }^{15}$. Çalışmamızda en sık görülen malign tümörün adenoid kistik karsinom olması çalışmaya dahil olan hasta sayısının az olmasına bağlanmıştır.

Hastaların IİAB sonuçlarına göre parotisteki kitlelerin $\% 84,8$ 'i benign, geri kalan \%15,2 sinde ise malign olarak raporlandı. Fakhry ve arkadaşlarının 249 hastanın parotis kitlelerinde uyguladıkları İIAB sonuçlarına göre lezyonların \%75'i benign, \%25'i malign bulunmuşlar ${ }^{16}$. Basavanandswami ve arkadaşları parotisteki lezyonların \%70'den fazlasının benign tümör olduğunu ifade etmişlerdir ${ }^{14}$.

Postoperatif histopatolojik tanılarına göre kitlelerin $28 / 33$ ü $(\% 84,8)$ benign lezyon (25 neoplazm ve 3 non-neoplastik lezyon), 5/33’ü (\%15,2) malign neoplazmdı. Lin CC ve arkadaşları, parotidektomi operasyonu olan 276 hastanın postoperatif tanılarını incelediler; ve 229 (\%85) benign, 33 (\%12) malign ve 9 (\%3) kronik inflamasyon tanısıyla karşılaştılar ${ }^{17}$. Jose Granel ve arkadaşları, parotidektomi operasyonu olan 52 hastanın postoperatif patolojik tanılarının 39'unu (\%75) benign, 13'ünü (\%25) malign olarak raporladılar ${ }^{18}$.

İİAB'de onkositik tümörlerin adenoid kistik karsinomdan ayrımı; monomorfik ve pleomorfik adenomların adenoid kistik karsinomdan ayrımı; düşük grade mukoepidermoid karsinomun pleomorfik adenomdan-Warthin tümöründen-kronik sialadenitten-retansiyon kistlerinden ayrımı ve yüksek grade mukoepidermoid karsinomun metastatik karsinomlardan ayrımının yapılması konusunda sorunlar mevcuttur ${ }^{19-22}$. İçerisinde kistik odaklar, lenfoid stroma, duktal hücreler bulunan Warthin tümörünün İIAB'sinde ayırıcı tanıda bazı karışıklıklar olabilir. Bahar ve arkadaşları 256 hastalık serilerindeki 5 Warthin tümörlü hastada akut parotitis bildirmişler$\operatorname{dir}^{23}$. Bizim çalı̧̧mamızdaki 2 Warthin tömürlü hastanın İİAB'leri; yoğun nötrofil, lenfosit ve inflame kist olarak raporlanmıştı.

Çalışmalarda yanlış pozitif ve yanlış negatif değerlendirme oranlarının düşük olması ve bunlarda da yineleme yapilabilmesi İİAB'ye olan güveni arttırmıştır ${ }^{24}$. Bizim çalı̧̧mamızda yanlış pozitif ve yanlış negatif olarak değerlendirilen olgu sayısı birerdi.

İ̇AB’nin uygulanma zamanı konusunda da farklı görüşler bulunmaktadır. Bazı yazarlar radyolojik tetkiklerden özellikle BT ve MRG gibi teknik güçlük ve yüksek ekonomi isteyen tetkiklerden önce yapılmasını önermekte ve bu yöntemlere çoğu kez gerek bırakmayacağını bildirmekteyken, bazı yazarlar ise İİAB'yi radyolojik yöntemlerin tamamlayıcısı olarak görmektedir. Bir başka grup ise radyolojinin İİAB için yol gösterici, rehber olmasını ve birlikte uygulanmasını önermekte, bu şekilde uygulamanın tanı oranını yükselteceğini belirtmektedir ${ }^{24-26}$.

Bazı yazarlar ise İIAB'nin operasyon planlamasını değiştirmediğini belirterek hastanın tedavisine bir katkısı olamayacağını bildirmektedir ${ }^{24}$. İİAB'nin tükürük bezi kaynaklı kitlelerin tanısında kullanılması ile ilgili tartışmalar yıllardır süregelmektedir ve halen tartışmalıdır ${ }^{20,27}$. Spiro ve arkadaşları, İIAB'nin eskiden çok savunulmasına karşın giderek terk edilmesini, relatif olarak yanlış sonuçlar vermesine bağlamaktadır. Yazarın, 144 hastalık serisinde \%21 oranında teşhis verememiş ve $\% 17$ oranında da yanlış negatif benign sonuç vermiştir. Spiro, doğru sonuç bile verse tedavi sürecini değiştirmediğini ifade ediyor ${ }^{28}$. Olsen, tekniğin tartışmalı olduğunu, nadiren doğru sonuç verdiğini ve yanlış negatif ve yanlış pozitif sonuçların yüksek olduğunu ifade etmektedir. Genel olarak, zaten, parotis bölgesindeki geçmeyen bir kitlesel lezyonun eksizyon endikasyonu doğurduğunu ve İİAB'nin gereksiz olduğunu söylemektedir ${ }^{29}$. Conley 1975 'te yayımladığ 1 kitabından önce çok düşük sayıda İ̇AB yaptığını ve bu yöntemin yararsız olduğunu, İİA yerine per-operatif Frozen Section (FS)'in uygulanması gerektiğini ifade etmektedir ${ }^{30}$. Spiro da İİAB'nin yalnızca derin lob veya parafarengeal uzanımlı olduğu düşünülen parotis kitlelerinde ve submandibuler bölgedeki kitlenin glanda ait olup olmadığı ve neoplastik olup olmadığının ayrımında kullanılması gerektiğini ifade etmektedir ${ }^{31}$. 
Çalışmamızda tespit ettiğimiz yüksek duyarlılık ve özgüllük değerleri de literatür verileri ile korelasyon göstermektedir.

İIAB’nin değerlendirilmesinin deneyimli ve bu konuda yetkinleşmiş patologlar tarafindan yapılması gereklidir ${ }^{24}$.

\section{Sonuç}

IİAB parotis kitlelerinde kolay uygulanan, çabuk ve güvenilir sonuç veren, duyarlılık ve özgüllügü yüksek, ucuz ve risksiz erken tanı yöntemidir.

\section{Kaynaklar}

1. Spiro RH. Salivary neoplasms: overview of a 35-year experience with 2, 807 patients. Head Neck Surg 1986;8:177-84.

2. Pinkston JA, Cole P. Incidence rates of salivary gland tumors: results from a population-based study. Otolaryngol Head Neck Surg 1999; 120:834-40.

3. Eveson JW, Cawson RA. Salivary gland tumours. A review of 2410 cases with particular reference to histological types, site, age and sex distribution. J Pathol 1985;146:51-8.

4. Bialek EJ, Jakubowski W, Zajkowski P, et al. US of the major salivary glands: anatomy and spatial relationships, pathologic conditions, and pitfalls. Radiographics 2006;26:745-63.

5. Yabuuchi H, Matsuo Y, Kamitani T, et al. Parotid gland tumors: can addition of diffusion-weighted MR imaging to dynamic contrast-enhanced MR imaging improve diagnostic accuracy in characterization? Radiology 2008;249:909-16.

6. Engin K, Erişen L. Baş-Boyun Kanserlerinin Genel Patolojik Özellikleri. In: Yerci Ö, Adım Ş. Balaban Ö, et al. editörler. Baş-Boyun Kanserleri. Bursa: Nobel Tip Kitabevi Ltd Şti.;2003:113-4.

7. Engzell U, Esposti PL, Rubio C, et al. Investigation on tumour spread in connection with aspiration biopsy. Acta Radiol Ther Phys Biol 1971;10:385-98.

8. Cohen MB, Ljung BM and Boles R. Salivary gland tumors. Fineneedle aspiration vs frozen-section diagnosis. Arch Otolaryngol Head Neck Surg 1986;112:867-9.

9. Layfield LJ, Tan P and Glasgow BJ. Fine-needle aspiration of salivary gland lesions. Comparison with frozen sections and histologic findings. Arch Pathol Lab Med 1987;111:346-53.

10. Mohammed F, Asaria J, Payne RJ, et al. Retrospective review of 242 consecutive patients treated surgically for parotid gland tumours. J Otolaryngol Head Neck Surg 2008;37:340-6.

11. Atula T, Greenman R, Laippala P, et al. Fine-needle aspiration biopsy in the diagnosis of parotid gland lesions: evaluation of 438 biopsies. Diagn Cytopathol 1996;15:185-90.

12. Seethala RR, LiVolsi VA and Baloch ZW. Relative accuracy of fine-needle aspiration and frozen section in the diagnosis of lesions of the parotid gland. Head Neck 2005;27:217-23.
13. Piccioni LO, Fabiano B, Gemma $M$, et al. Fine-needle aspiration cytology in the diagnosis of parotid lesions. Acta Otorhinolaryngol Ital 2011;31:1-4.

14. Hartimath B, Kudva A and Singh Rathore A. Role of fineneedle aspiration cytology in swellings of the parotid region. Indian J Surg 2011;73:19-23.

15. Jafari A, Royer B, Lefevre M, et al. Value of the cytological diagnosis in the treatment of parotid tumors. Otolaryngol Head Neck Surg 2009; 140:381-5.

16. Fakhry N, Antonini F, Michel J, et al. Fine-needle aspiration cytology in the management of parotid masses: evaluation of 249 patients. Eur Ann Otorhinolaryngol Head Neck Dis 2012;129:131-5.

17. Lin CC, Tsai MH, Huang CC, et al. Parotid tumors: a 10-year experience. Am J Otolaryngol 2008;29:94-100.

18. Granell J, Sanchez-Jara JL, Gavilanes J, et al. Management of the surgical pathology of the parotid gland: A review of 54 cases. Acta Otorrinolaringol Esp 2010;61:189-95.

19. Layfield LJ and Glasgow BJ. Diagnosis of salivary gland tumors by fine-needle aspiration cytology: a review of clinical utility and pitfalls. Diagn Cytopathol 1991;7:267-72.

20. O'Dwyer P, Farrar WB, James AG, et al. Needle aspiration biopsy of major salivary gland tumors. Its value. Cancer 1986;57:554-7.

21. Zajicek J, Eneroth CM and Jakobsson P. Aspiration biopsy of salivary gland tumors. VI. Morphologic studies on smears and histologic sections from mucoepidermoid carcinoma. Acta Cytol 1976;20:35-41.

22. Eneroth CM and Zajicek J. Aspiration biopsy of salivary gland tumors. IV. Morphologic studies on smears and histologic sections from 45 cases of adenoid cystic carcinoma. Acta Cytol 1969;13:59-63.

23. Bahar G, Dudkiewicz M, Feinmesser R, et al. Acute parotitis as a complication of fine-needle aspiration in Warthin's tumor. A unique finding of a 3-year experience with parotid tumor aspiration. Otolaryngol Head Neck Surg 2006;134:646-9.

24. Yılmaz O. Klinik Yönden Histopatoloji ve İnce İğne aspirasyon Biyopsisinin Tanıdaki Yeri. Kulak Burun Boğaz ve Baş Boyun Cerrahisinde Güncel Yaklaşım 2006;2:13-5.

25. YoungJA. Fine needle aspiration cytology of salivary glands. Ear Nose Throat J 1989;68:120-9.

26. Shah KA. Fine needle aspiration.J Laryngol Otol 2003;117:493-5.

27. Heller KS, Dubner S, Chess Q, et al. Value of fine needle aspiration biopsy of salivary gland masses in clinical decisionmaking. Am J Surg 1992;164:667-70.

28. Spiro RH, Huvos AG and Strong EW. Cancer of the parotid gland. A clinicopathologic study of 288 primary cases. Am J Surg 1975;130:452-9.

29. Olsen KD. The parotid lump - don't biopsy it! An approach to avoiding misadventure. Postgrad Med 1987;81:225-9.

30. Conley JJ. Salivary Glands and the Facial Nerve. In: Conley JJ, editor. Surgical anatomy relative to the parotid gland. Stuttgart: Thieme Verlag; 1975:7-13.

31. Spiro RH. Changing trends in the management of salivary tumors. Semin Surg Oncol 1995;11:240-5. 


\title{
Ameliyat Sonrası Ağrı Yönetiminde Nitelik Değișimi: İki Periyodun Karșılaștırılması

\author{
Quality Changes in Postoperative Pain Management: Comparison of Two Periods
}

\author{
Elif Dirimeșe', Meryem Yavuz², Yasemin Altınbaș² \\ ${ }^{1}$ Kafkas Üniversitesi Kars Sağllk Yüksekokulu, Hemşirelik Bölümü, Kars; ${ }^{2}$ Ege Üniversitesi Hemşsirelik Fakültesi, Cerrahi Hastalıkları \\ Hemşireliği Anabilim Dal, İzmir
}

\begin{abstract}
AIM: To evaluate the changes in the quality of postoperative pain management in five years time in the same health institute.

METHODS: This observational study was conducted in the General Surgery and Cardiovascular Surgery clinics of Ege University School of Medicine. The sample included 103 and 96 patients operated in 2008 and 2013, respectively. Data was collected by using a questionnaire with face to face interview in the second post-operative day. The data of the two time periods was compared and analyzed appropriately.
\end{abstract}

RESULTS: Mean age of the participants was $57.34 \pm 12.35$ and 51.9 \pm 15.76 years in 2008 and 2013, respectively. Although the minimum pain score and the pain score during interview increased from 2.1 to 2.3 and from 2 to 2.6, respectively, the change between two study years was not significant ( $p>0.05$ ). However, satisfaction from the pain management regime decreased from 8.6 to $6.9(p<0.01)$.

Pain management quality monitoring survey scores were lower in 2013; however the differences were not significant. Honesty, communication, intervention and environment scores decreased from 16.2 to 15.9 , from 13.6 to 13.5 , from 7.2 to 6.1 , and from 25.4 to 23.6, respectively, however the changes were not significant ( $p>0.05)$.

CONCLUSION: It seems that the quality of pain management has not been improved and patients experience same levels of pain over a period of five years. However, they express more dissatisfaction.

Key words: health care quality assurance; health care; pain; postoperative; pain management; quality assurance; quality improvement

\section{ÖZET}

AMAÇ: Aynı sağlık kurulușunda beș yıllık süre içerisinde ameliyat sonrası ağrı sağaltımındaki değișimleri belirlemektir.

YÖNTEM: Bu gözlemsel çalıșma Ege Üniversitesi Tıp Fakültesi Hastanesi'nin Genel Cerrahi ve Kalp Damar Cerrahisi kliniklerinde

Yard. Doc. Dr. ElifDirimeşe, Kafkas Üniversitesi Kars Să̆lık Yüksek Okulu, Hemşirelik Bölümü, Kars, Türkiye, Tel.0 5052249085 Email.elifim67@yahoo.com Gelis Taribi: 03.10.2013 • Kabul Taribi: 17.03.2014 yapıldı. Örneklem sırasıyla 2008 ve 20013 yıllarında ameliyat olan 103 ve 96 hastayı içerdi. Veriler ameliyat sonrası ikinci günde yüz yüze görüșme ile bir anket formu kullanılarak toplandı. Iki zaman aralığının verileri uygun yöntemlerle karșılaștırıldı ve incelendi.

BULGULAR: Katılımcıların yaș ortalamaları 2008 ve 2013'te sırasıyla $57.34 \pm 12.35$ ve $51.9 \pm 15.76$ 'ydı. En düșük ağrı skoru ve görüșme anındaki ağrı skoru sırasıyla 2,1'den 2,3'e ve 2'den 2,6'ya yükselse de, çalıșma süresince olușan değișiklik anlamlı değildi (p>0,05). Ancak, ağrı sağaltımı yönteminden memnuniyet 8,6'dan 6,9'a düșmüștü $(p<0.01)$.

Ağrı sağaltımı kalite izlemi anketi skorları 2013'te daha düșüktü, ancak fark anlamlı değildi. Dürüstlük, iletișim, girișim ve çevre skorları sırasıyla 16,2'den 15,9'a, 13,6'dan 13,5'e, 7,2'den 6,1'e ve 25,4'den 23,6'ya düșmüștü, ancak değișimler anlamlı değildi (p>0,05).

SONUÇ: Ameliyat sonrası ağrı sağaltımının kalitesi artmamıș gibi görünmektedir ve beș yıllık bir dönemde hastalar aynı seviyede ağrı hissetmektedir. Ancak, hastalar daha fazla memnuniyetsizlik ifade etmektedir.

Anahtar kelimeler: sağlık hizmetleri kalite teminatl; sağlık hizmetleri; postoperatif; ağrı sağaltımı; kalite teminatı; kalite gelișimi

\section{Giriș}

Ağrı vücudun belli bir bölgesinden kaynaklanan gerçek ya da potansiyel doku hasarı ile ilişkili olan ya da olmayan, bireyin geçmiş deneyimleriyle ilişkili, duyusal ve duygusal bir deneyim olarak tanımlanmaktadır (International Association for the Study of Pain) ${ }^{1,2}$. Ağrının subjektif özelliğinden dolayı klinik olarak değerlendirilmesi ve yönetimi karmaşık bir süreci ortaya çıkarmaktadır. Ağrının beşinci yaşam bulgusu olarak değerlendirilmesi, bu karmaşık sürecin ilk basamağını oluşturmaktadır ${ }^{3,4}$.

Ağrı cerrahi işlemler sonrasında en beklendik sonuçlardan biridir. Günümüzde geliştirilen etkili ağrı 
giderme yöntemlerine rağmen, hala milyonlarca insan ağrı çekmektedir. Amerika'da hastaların \%80'nin ameliyat sonrası ağrı yaşadığ 1 ve bunun \%86'sının orta, şiddetli ve dayanılmaz nitelikte olduğu bildirilmiştir ${ }^{5}$. Hollanda'da yapılan bir kohort çalışmada $(n=149)$, ameliyat sonrası standart bir ağrı tedavisine rağmen hastaların \%40'nın dinlenme halinde iken orta ya da şiddetli ağrı yaşadıkları ortaya konmuştur ${ }^{6}$. Ameliyat sonrası ağrı yönetimindeki en önemli amaç; rahatsızlığ 1 en aza indirgemek ya da yok etmek, hastanın iyileşme sürecini kolaylaştırmak ve olası komplikasyonları önlemektir ${ }^{7,8}$.

Ağrı yönetimindeki başarısızlığın nedenleri karmaşıktır ancak büyük çoğunlukla bilgi ve ağrının tanılanmasindaki yetersizlikten kaynaklanmaktadır. Strode ve arkadaşlarının $(2008)^{3}$ yaptığı çalışmada; hemşirelerin $(n=309) \% 81$ 'inin ağrının tanılanmasında subjektif yöntemleri kullandığı, buna karşın sadece \%5'inin visuel analog skala, \%22'sinin sözel skala, \%16'sının sayısal skala ile ağrıyı değerlendirdikleri ortaya konulmuştur. Klinik ortamların birçoğunda ağrı yönetimi niteliğini geliştirmeye yönelik çalışmalar yapılmasına rağmen, ağrı yönetimindeki değişkenliğin bu durumu güçleştirdiği bildirilmektedir ${ }^{1,9}$. Ağrı yönetiminde; bilgi eksikliği, ağrı tanılamada yetersizlik, iletişim eksikliği, tutum farklılığı, sistematik kayıtların yetersizliği gibi faktörler bakımın niteliğini olumsuz yönde etkilemektedir. Gordon ve arkadaşları $(2002)^{10}$ tarafindan yapılan sistematik literatür incelemesinde, hastanelerde ağrı yönetimine yönelik altı kalite göstergesi belirlenmiştir. Bu göstergeler; ağrının şiddetinin sayısal ya da sözel tanımlayıcı skalalar ile kaydedilmesi, ağrı şiddetinin sık aralıklarla kaydedilmesi, ağrının intramüsküler yöntemler dışında farklı yöntemlerle tedavi edilmesi, ağrının düzenli analjezik ile tedavi edilmesi, ağriyı giderme, yaşam kalitesi ve günlük yaşam aktivitelerini kolaylaştıracak düzeyde kontrol altına alma, hastalara yeterli bilgi verme ve ağrı yönetimi hakkında bilgilendirmedir.

Usichenko ve arkadaşlarının (2012) ${ }^{11}$ yaptığı çalışmada ağrının kontrolüne yönelik kalite yönetimi sistemi oluşturulmuştur. $\mathrm{Bu}$ sistemde hastayı bilgilendirme, multimodal analjezi protokolü uygulama, ağrının değerlendirilmesi, ağrı tedavisinin yan etkilerinin saptanması, akut ağrı biriminin kurulması ve ekipler arası iletişim ağı yer almıştır. Çalışma sonucuna göre hastaların günlük yaşam aktivitelerinden; genel aktivite, ruh hali, diğer insanlarla ilişkiler, yaşamdan zevk alma durumunun ameliyat sonrası ve taburcu olduktan 6 ay sonraki değerlendirmelerin benzerlik gösterdiği, buna karşın uyku ve ağrı tedavisine yönelik memnuniyet puanının ameliyat sonrası erken evrede anlamlı olarak yüksek olduğu bildirilmiştir. Kalite yönetimi sisteminin ameliyat sonrası hastaların yaşam kalitesini ve memnuniyetini olumlu yönde etkilediği ortaya konmuştur.

Ameliyat sonrası ağrı yönetim sonuçlarının bilinmesi, etkili hemşirelik uygulamaları geliştirilmesine katkı sağlaması açısından önemlidir. Ülkemizde ağrı yönetimi kalite göstergelerin tanımlandığı çalışmalar yok denecek kadar azdır. Bunun yanı sıra çalışmalara temel oluşturacak ağrı ile ilgili veriler de yetersizdir. Bu nedenle ağrı yönetim sonuçlarını ölçen çalışmalara gereksinim vardır. Bu çalışmanın amacı, aynı sağlık kuruluşunda beş yıllık süre içerisinde ameliyat sonrası ağrı sağaltımındaki değişimleri belirlemektir.

\section{Yöntem}

Tanımlayıcı tipte olan bu araştırma, 2008 ve 2013 yıllarında iki ayrı dönemde prospektif olarak yürütülmüştür. Araştırmaya başlamadan önce yerel etik kuruldan etik izin, çalışmanın yürütüldüğü kurumdan yazılı izin alınmış ve çalışma süresince Helsinki Deklerasyonu kriterlerine uyulmuştur. Veri toplama aşamasında hastalardan sözel onam alınarak, anket sadece araştırmaya katılmaya gönüllü olan hastalara uygulanmıştır.

\section{Evren ve Örneklem}

Araştırmada örnekleme yöntemine gidilmemiş, 14 Ocak - 30 Nisan 2008 ve 4 Şubat - 31 Mayıs 2013 tarihlerinde Ege Üniversitesi Tıp Fakültesi Hastanesinin Genel Cerrahi ve Kalp Damar Cerrahisi Servislerinde yatan tüm hastalara ulaşılmaya çalışılmıştır. Çalışmanın örneklemini göğüs ve batına cerrahi girişim yapılan 2008 yilında 103 hasta, 2013 yilında ise 96 hasta toplamda 199 hasta oluşturmuştur. Ameliyatlar açık ve kapalı cerrahi yöntem, yara büyüklügü ve anestezi süresi değişkenlerine göre majör ve minör cerrahi olarak gruplandırılmıştır.

\section{Veri Toplama Aracı}

Araştırmada, araştırmacı tarafindan oluşturulan Ağrı Yönetimi Kalite İzlemi Anketi kullanılmıştır. Anket; Idvall ve arkadaşları (2001) tarafından geliştirilen "Ameliyat Sonrası Ağrı Yönetimi Kalite Kriterleri Ölçeği”nden, Daut ve Cleeland (1982) tarafindan geliştirilen "Wisconsin Kısa Ağrı Envanteri” nden ve Amerika'da kalite gelişim izleminde 
kullanılan "Amerikan Ağrı Topluluğu Hasta Sonuçları Anketinden” yararlanılarak hazırlanmıştır ${ }^{9,10,12-15}$.

Ağrı Yönetimi Kalite İzlemi Anketi iki bölümden oluşmaktadır. Birinci bölümde yer alan 12 soru ameliyat sonrası ağrı yönetiminin kalitesine yönelik sorular olup, ikinci bölümde yer alan 4 soru hastaların ağrı şiddeti ve hasta memnuniyetine yönelik sorulardır. Birinci bölümdeki değerlendirme $0-5$ arasında; $0=$ hiç katılmıorum, 5 = tamamen katılıyorum; ikinci bölümdeki değerlendirme ise $0-10$ arasında, ağriya yönelik sorularda; 0 =ağrı yok, $10=$ dayanılmaz ağrı; memnuniyete yönelik soruda $0=$ hiç memnun değil, $10=$ çok memnun şeklinde yapılmıştır. Ankette yer alan sorular ameliyat sonrası kalite kriterlerine göre iletişim, girişim, dürüstlük ve çevre başlıkları altında gruplandırılmıştır (Tablo 1). Bu gruplandırmalarda iletişim; sağlık personeli ile ağrı yönetimi konusundaki iletişimi, girişim; ağrı tanılaması ve ağrı yönetimi konusunda yapılan uygulamaları, dürüstlük; sağlık ekibinin hastaya ağrı yönetimi konusunda yeterliliğe sahip olduğunu hissettirmesi, çevre; uygun ortam ve ağr1, memnuniyet düzeylerini göstermektedir. Araştırma verilerinin elde edildiği her iki yılda da aynı anket kullanılarak hastalarla ameliyat sonrası ikinci günde görüşme yapılmıştır.

\section{Çalıșma Ortamı}

$\mathrm{Bu}$ araştırma Ege Üniversitesi Tıp Fakültesi Hastanesinin Genel Cerrahi ve Kalp Damar Cerrahisi servislerinde yürütülmüştür. Bu kliniklerde, ameliyat sonrası ağrı tedavisine yönelik multimodal yaklaşım esasına dayalı öncelikle parasetamol ve daha sonra nonsteroid antiinflamatuar ilaç (NSAIII) ve zayıf opioidlerin eklenmesi ile hastanın ağrisına ve uygulanan analjeziğge olan yanıtına göre rutin bir analjezi protokolü uygulanmaktadır. Bu kliniklerde 2008 yılında ağrının değerlendirilmesine yönelik rutin bir uygulama yer almazken, 2013 yılında ağrı değerlendirilmesi için özel bir "ağrı değerlendirme formu" kullanılmaya başlanmıştır. Bu formda ağrının değerlendirilmesine yönelik 7 yaş üstü erişkin hastalarda $0-10$ sayısal skala, 7 yaş altı ve konuşamayan erişkin hastalarda $0-10$ arası yüz skalası kullanılmaktadır.

\section{Verilerin Değerlendirilmesi}

Anketten alınabilecek alt ve üst puanlar; iletişim alt grubunda 4 soru (0-20 puan), girişim alt grubunda 2 soru (0-10 puan), dürüstlük alt grubunda 4 soru (0-20 puan), çevre alt grubunda 6 soru $(0-50$ puan) şeklindedir. Buradan elde edilen veriler SPSS 16.0 paket programı ile sayı ve yüzdelikler, ortalama, t-testi, varyans analizi kullanılarak değerlendirilmiştir. Yıllara göre ağrı puanları, memnuniyet puanları, ağrı yönetimi kalite izlemi anket puanları karşılaştırilmıştır. Önemlilik düzeyi olarak p $<0,05$ anlamlı kabul edilmiştir.

\section{Bulgular}

Araştırma örneklemini oluşturan hastaların 2008 yılındaki özellikleri incelendiğinde \%40,8'ine $(n=42)$

Tablo 1. Ağrı yönetimi kalite izlemi anketi

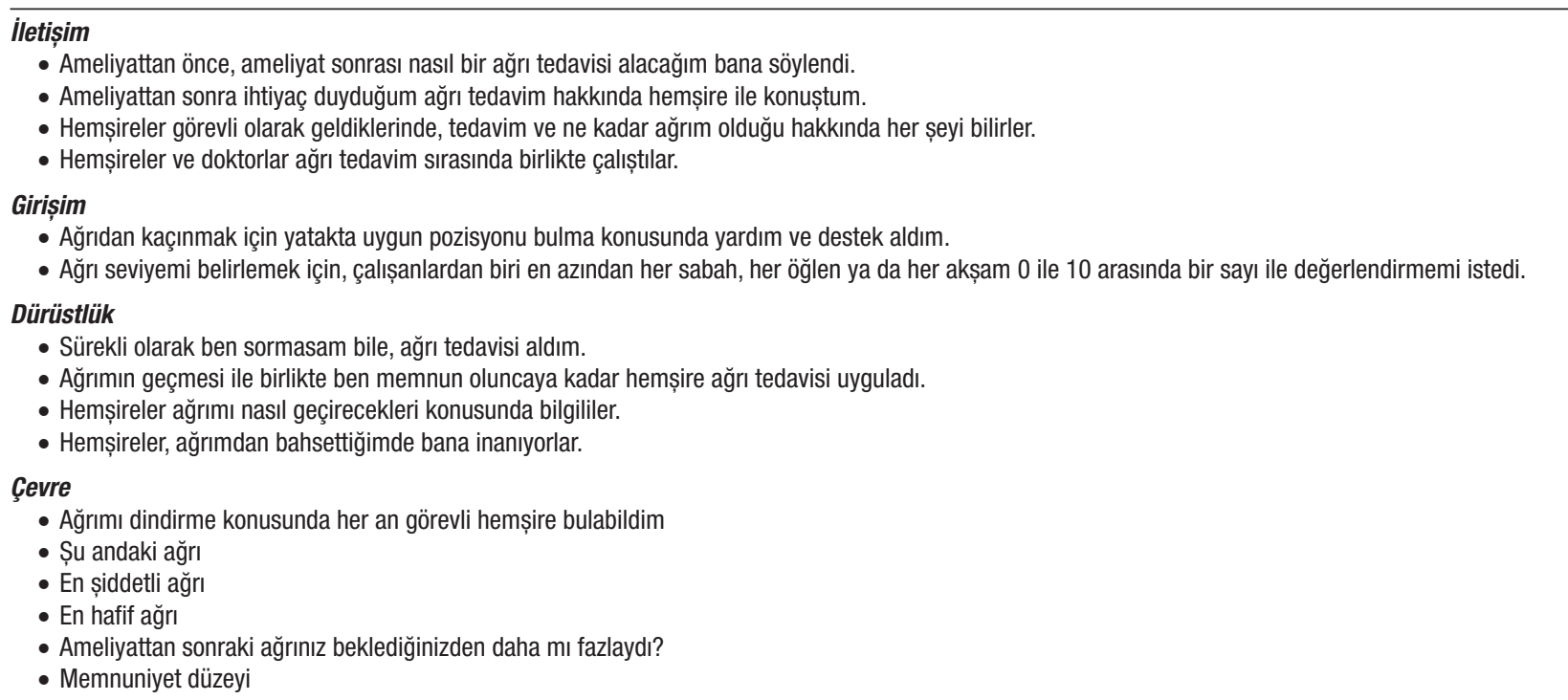


göğüs cerrahisi, \%59,2'sine $(\mathrm{n}=61)$ batın cerrahisi yapıldığ 1 , yaş ortalamasının $57,34 \pm 12,35$ yıl, cinsiyetin $\% 56,3$ ünün erkek ve eğitim durumunun \%46,6'sının ilköğretim düzeyinde olduğu görülmüştür. 2013 yılında ise \%41,7'sine $(n=40)$ gögüs cerrahisi, \%58,3'üne $(\mathrm{n}=56)$ batın cerrahisi yapıldı̆̆ $51,9 \pm 15,76$ yaş, cinsiyetin \%51'inin erkek ve eğitim durumunun \%43,8'inin ilköğretim düzeyinde olduğu belirlenmiştir.

İnsizyon büyüklügüne göre ameliyat tipi değerlendirildiğinde; \%24,1'ine $(\mathrm{n}=48)$ açık kalp cerrahisi, \%17,1'ine ( $\mathrm{n}=34)$ kapalı kalp cerrahisi, \%26,6'sina $(n=53)$ minör batın cerrahisi, \%32,2'sine $(n=64)$ majör batın cerrahisi yapıldığı görülmüştür.

Hastaların ameliyat sonrası 2. gündeki ağrısı incelendiğinde, 0-10 sayısal skalaya göre 2008 yılında en şiddetli ağrının ortalama 6 , en hafif ağrının 2,1 , görüşme anındaki ağrının 2 puan olduğu, 2013 yılında ise en şiddetli ağrının ortalama 5,9, en hafif ağrının 2,3, görüşme anındaki ağrının 2,6 puan olduğu görülmüştür (Grafik 1). Yapılan t-testi sonucuna göre yıllara göre ağrı puanları arasında istatistiksel olarak anlamlı fark saptanmamıştır $(p>0,05)$.

Benzer olarak yapılan tek yönlü varyans analizi sonucunda ameliyat tiplerine göre ağrı puanlarındaki farkın anlamlı olmadığ 1 belirlenmiştir (Tablo 2).

Hastaların ameliyat sonrası ağrı beklenti durumu incelendiğinde; 2008 yılında $\% 76$ 'sı, 2013 yılında \%57,3’ü beklediğinden fazla olmadığını ifade etmişlerdir. Hastaların ağrılarına yönelik aldıkları tedaviden 0-10 sayısal skalaya göre memnuniyet puan ortalamasının 2008 yilında 8,6, 2013 yılında 6,9 puan olduğu görülmüştür. Yapılan t-testi sonucuna göre yıllara göre memnuniyet puanları arasındaki farkın istatistiksel olarak anlamlı olduğu belirlenmiştir $(t=14, p=0,00)$ (Grafik 2). Ameliyat tipine göre ise kalp ve damar cerrahisi ameliyatı yapılan hastaların memnuniyet puan

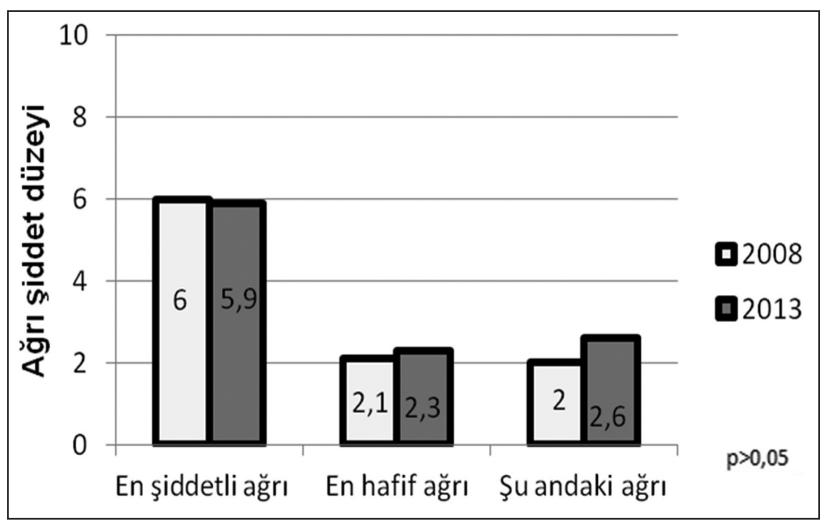

Grafik 1. Hastaların ağrı puan ortalamaları.

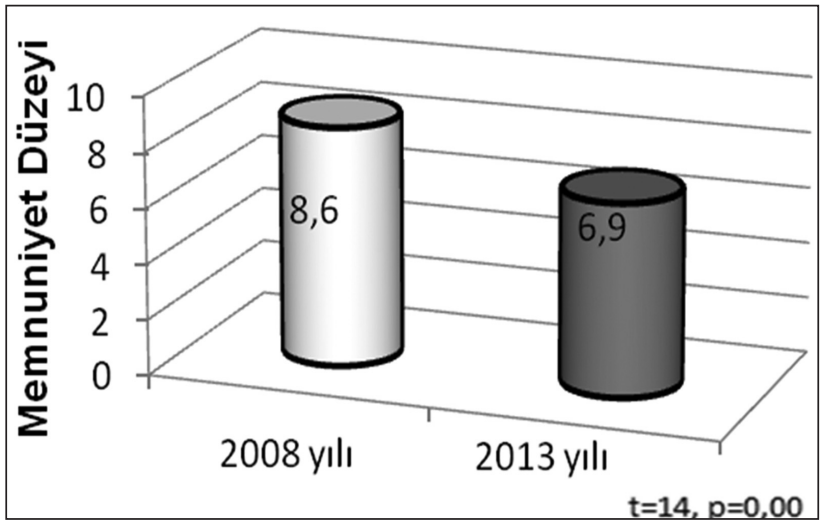

Grafik 2. Hastaların ağrı tedavisine yönelik memnuniyet puanları.

ortalamalarının 7,96; genel cerrahi hastalarının ise 7,72 puan olduğu görülmüştür.

Ağrı Yönetimi Kalite İzlemi Anketine göre hastaların aldıkları puan ortalamalarının 2008 yılında; iletişimde 13,63 , girişimde 7,2 , dürüstlükte 16,17 , çevrede 25,38 puan, 2013 yılında ise iletişimde 13,48, girişimde 6,1, dürüstlükte 15,92, çevrede 23,64 puan olduğu görülmüştür. Yapılan t testi sonucuna göre yıllara göre Ağrı Yönetimi Kalite İzlemi Anketi puanları arasında istatistiksel olarak anlamlı fark saptanmamıştır $(p>0,05)$.

Tablo 2. Ameliyat tiplerine göre ağrı puanları

\begin{tabular}{lcccccc}
\hline & \multicolumn{5}{c}{ Ameliyat Tipleri } \\
\cline { 2 - 6 } & KKA & AK & MGC & MnGC & F & P \\
\hline En fazla ağrı & 5,7 & 6,1 & 6,3 & 5,7 & 0,562 & 0,641 \\
En az ağıı & 1,8 & 2,7 & 2,6 & 2,0 & 1,974 & 0,119 \\
Görüșme anındaki ağıı & 2,1 & 2,4 & 2,4 & 2,3 & 0,239 & 0,869 \\
KKA: Kapalı kalp ameliyatı, AKA: Açık kalp ameliyatı, MGC: Major genel cerrahi, MnGC: Minör genel cerrahi & & & \\
\hline
\end{tabular}




\section{Tartıșma}

Bu çalışmada 2008 ve 2013 yıllarında hastaların demografik özelliklerinin benzerlik gösterdiği ve ameliyat sonrası ikinci günde en şiddetli ağrı puan ortalamasının orta düzeyde olduğu görülmüştür.

Hemşirelik bakım kalitesinin sürdürülmesinde ameliyat sonrası ağrı yönetiminin etkin bir şekilde sağlanması esastır. Ağrı yönetimindeki bütüncül yaklaşımın hedefi hastanın ameliyat sonrasındaki rahatsızlığını en aza indirmektir ${ }^{16}$. Sekiz Avrupa ülkesi ve İsrail'de yürütülen bir çalışmaya göre $(\mathrm{n}=4.576)$ ameliyattan 24 saat sonra hastaların en şiddetli ağrı puan ortalamalarının 5,16 olduğu ${ }^{17}$; Sloman ve arkadaşlarının yaptıkları çalı̧mada ${ }^{18}$ cerrahi hastalarının $\% 75^{\prime}$ inin şiddetli ve orta düzeyde ağrı hissettikleri, ülkemizde ise Özer ve arkadaşlarının ${ }^{19}$ yaptıkları çalışmada hastaların \%93,7'sinin şiddetli, \%50,2'sinin yanma/sızı şeklinde ağrı yaşadıkları belirlenmiştir. Literatürde ağrının etkin bir şekilde kontrol edilmesine yönelik uygulanan kalite yönetimi sonuçlarına göre hastaların ameliyat sonrası yaşadığı en şiddetli ağrı puanında anlamlı olarak azalma olduğu gösterilmiştir ${ }^{11}$.

Ağrı beklentisinin ve hasta memnuniyetinin değerlendirilmesi kalite sonuçları açısından oldukça önemlidir. Bu çalışmada 2008 yılından 2013 yılına doğru hastaların duydukları ameliyat sonrası ağrının beklediğinden az olduğu, buna karşın memnuniyet puanının da anlamlı şekilde azaldığı belirlenmiştir. Literatürde ağrı yönetimi ve hasta memnuniyetine yönelik farklı sonuçlar yer almaktadır. Rothoug ve arkadaşları hastaların ameliyat sonrası ağrı yönetimine yönelik algılarını değerlendirdikleri çalı̧̧mada ${ }^{17}$ hastaların orta şiddette ağrı duyduklarını, ancak hasta memnuniyetinin yüksek olduğunu tespit etmişlerdir.

Brown ve arkadaşları ${ }^{20}$ ise kolorektal cerrahi grubunda yaptıkları çalışma sonucunda ameliyat sonrası ağrı beklentisinin şiddetli ağrı ya da hasta memnuniyetiyle ilişkili olmadığını belirlemişlerdir. Ayrıca mevcut çalışmalarda ve klinik uygulamalarda ameliyat sonrası ağrıyı kontrol altına alma ve azaltmaya yönelik farklı cerrahi tekniklere, farmakolojik tedavi yöntemlerine odaklanıldığı görülmektedir ${ }^{21,22}$. Bu uygulamaların yanı sıra hasta memnuniyetinin artırılmasına yönelik; hastanın ağrı ve anksiyete seviyesinin belirlenmesi, hasta için uygun fiziksel aktivite, insizyon yerinin korunması, masaj, relaksasyon teknikleri gibi nonfarmakolojik girişimlere karar verilmesi ve uygulanması, hastanın tepkilerinin ve uygulamalarının etkinliğinin değerlendirilmesi de önemli bir yere sahiptir. Bu girişimler hemşirelerin aktif rol üstlendiği uygulamalardır ${ }^{23,24}$. Buna karşın hemşirelerin ve diğer sağlık profesyonellerinin modern ağrı tedavi yöntemleri, ağrı şiddetini tanımlama, farmakolojik ve nonfarmakolojik ağrı tedavi yöntemlerini uygulama ile ilgili bilgi eksiklikleri olduğu bilinmekte$\operatorname{dir}^{25}$. Ay ve Alpar, hemşirelerin \%77,2'sinin ameliyat sonrası ağrıyı azaltmada en fazla bağımlı rollerinden analjezik uygulaması yaptıklarını ortaya koymuşlar$\mathrm{d}_{1}{ }^{23}$. Hemşirelik kayıtlarının incelendiği çalışmalarda, hemşirelerin en sık kayıt işlemini yaptıkları ve en çok zaman harcanan durumun bu olduğu ortaya konmuş$\operatorname{tur}^{26,27}$. Kayıt ile birlikte artan iş yükü sonucunda hemşirenin hasta başında geçirdiği zamanda azalmaya ve hasta memnuniyetine olumsuz yansimaya neden olabilir. Ayrıca hastanın daha önceki deneyimleri, kültürel inançları, bilinç düzeyinin artması gibi sebeplerden dolayı hasta beklentilerinde ve memnuniyette değişim görülebilir ${ }^{28}$.

Bu çalışmada 2013 yılında ağrı yönetimi kalite izlem anketine göre dürüstlük, iletişim, girişim ve çevre ölçüt puanlarının düştüğü, fakat farkların istatistiksel olarak anlamsız olduğu belirlendi. Literatürde benzer anket ile yapılan çalışma sonuçlarında da hastaların ağrı yönetimi bakım kalitesine yüksek puan verdikleri görülmüştür ${ }^{13,29,30}$. Ameliyat sonrası dönemde etkin ağrı kontrolünün sağlanmasında kalite çalışmalarının geliştirilmesi oldukça önemlidir. Bu süreçte yetersizliklerin belirlenerek giderilmesine yönelik önlemeler alınmalıdır. Kalite gelişimi, verilen bakımın niteliğinin düzenli aralıklarla ölçülmesini, yorumlanmasını ve sonuçlarının tartışılmasını içermektedir. Bu çalışmanın yürütüldüğü kliniklerde hastaların ağrılarının bir form aracılığı ile değerlendirilmesi kalite göstergeleri açısından önemli bir adımdır. Ancak literatürde ağrının ayrıntılı tanılanması ve ağrı yönetiminde standartlar belirlenmesi de vurgulanmaktadır ${ }^{12,14,15,29}$. Gunningberg ve Idval $(2007)^{29}$ ağrı yönetiminde yaptıkları kalite değerlendirmesinde hastaların ve hemşirelerin görüşleri ayrı ayrı ele almışlardır. Hastaların bakım kalitesine verdikleri puan hemşirelerinkine göre daha yüksekken, ağrısı fazla olan hastaların memnuniyetleri düşük olduğu bildirilmiştir.

Abdalrahim ve arkadaşlarının ${ }^{31}$ yaptığı çalı̧̧mada ise hemşirelere verilen eğitim sonrası ağrı yönetimi bakım sonuçlarının \%85 oranında anlamlı olarak geliştiği tespit edilmiştir. Amerika'da Sağlık Bakım Politikaları ve Araştırmaları Komitesi'nin (Agency for Health Care Policy and Research - AHCPR) akut ağrı yönetimi için geliştirdikleri klinik uygulama rehberinde 
hastanın kendisini ifade edebilmesi ve tedavinin etkisini değerlendirebilmesi konusunda eğitim sağlanmasinın, hasta konforunun ve memnuniyetinin arttırmanın komplikasyonları ve hastanede kalma süresini azaltaca$\breve{g} 1$ vurgulanmaktadır ${ }^{1}$.

$\mathrm{Bu}$ çalışmanın sonucunda iki farklı dönemde hastaların benzer düzeyde ağrı duydukları görülmüştür. Ulusal ve uluslararası rehberlerde belirtilen kalite kriterlerinin uygulama alanına aktarılmasında yetersizlik olduğu görülmektedir. Bu çalışma sadece batın ve gögüs cerrahisi yapılan hastalardaki ağrı sonuçlarını kapsamaktadır. Araştırmanın sınırlılıkları; ameliyat tiplerinin homojen olarak dağıtılmaması, ameliyat süresi, mevcut komplikasyon, önceki ameliyat öyküsü, hastanın beden kitle indeksi gibi verilerin ayrıntılı olarak ele alınmaması ve örneklem sayısının az olmasidir.

\section{Sonuç}

$\mathrm{Bu}$ araştırma, beş yıllık süre içerisinde ameliyat sonrası ağrı yönetiminde kalite kriterleri açısından istenen düzeyde gelişmenin sağlanamadığını göstermektedir. Bununla birlikte hastalar daha fazla memnuniyetsizlik bildirmektedirler.

\section{Kaynaklar}

1. Acute pain management: Operative or medical procedures and trauma. I. Agency for Health Care Policy and Research. Clin Pharm 1992;11:309-31.

2. Bogduk N. Ağrıya genel bir bakış. In: Terzi C, editör. Temel cerrahi bilimler. İzmir: Uşşak Matbaacılık; 2002:3-12.

3. Strode I, Seimane S. Assessment of acute pain in nursing practice in latvia. Int J Collaborative Research on Internal Medicine and Public Health 2011;3:320-6.

4. Francis L, Fitzpatrick JJ. Postoperative pain: Nurses' knowledge and patients' experiences. Pain Management Nursing 2013;14:351-7.

5. Apfelbaum JL, Chen C, Mehta SS, et al. Postoperative pain experience: results from a national survey suggest postoperative pain continues to be undermanaged. Anesth Analg 2003;97:534-40.

6. Sommer M, De Rijke JM, Van Kleef M, et al. The prevalence of postoperative pain in a sample of 1490 surgical inpatients. Eur J Anaesthesiol 2008;25:267-74.

7. Edirne S. Ağrı. İstanbul: Nobel Tıp Kitapevi; 2000:20-9.

8. Institute for Clinical Systems Improvement Health Care Guideline: Assessment and management of acute pain 6th Edition, 2008. [cited 2014 Aug 12]. Available from: http:// almacen-gpc.dynalias.org/publico/Tratamiento\%20dolor\%20 agudo\%20ICSI.pdf
9. American Pain Society Quality of Care Committee(APS). Quality improvement guidelines for the treatment of acute and cancer pain. JAMA 1995;274:1874-80.

10. Gordon DB, Pellino TA, Miaskowski C, et al. A 10-year review of quality improvement monitoring in pain management: Recommendations for standardized outcome measures. Pain Management Nursing 2002;3:116-30.

11. Usichenko TI, Röttenbacher I, Kohlmann T, et al. Implementation of the quality management system improves postoperative pain treatment: a prospective pre-/postinterventional questionnaire study. Br J Anaesth 2012;9:1-9.

12. Idvall E, Hamrin E, Sjöström B. Quality indicators in postoperative pain management: validation study. Scand J Caring Sci 2001;15:331-8.

13. Daut RL, Cleeland CS, Flanery RC. Development of the Wisconsin brief pain questionnaire to assess pain in cancer and other diseases. Pain 1983;17:197-210.

14. Idvall E, Hamrin E, Sjöström B, et al. Patient and nurse assessment of quality of care in postoperative pain management. Quality and Safety in Health Care 2002;11:327-34.

15. Idvall E, Hamrin E, Unosson M. Development of an instrument to measure strategic and clinical quality indicators in postoperative pain management. J Adv Nurs 2002;37:532-40.

16. Yüceer $S$. Nursing approaches in the postoperative pain management. Klinik ve Deneysel Araştırmalar Dergisi 2011;2:474-8.

17. Rothaug J, Zaslansky R, Schwenkglenks M. et al. Patients' perception of postoperative pain management: Validation of the international pain outcomes (IPO) Questionnaire. The Journal of Pain 2013;14:1361-70.

18. Sloman R, Rosen G, Rom M, et al. Nurses' assesment of pain in surgical patients. J Adv Nurs 2005;52:125-32.

19. Özer N, Bölükbaşı N. Postoperatif dönemdeki hastaların ağrıyı tanımlamaları ve hemşirelerin ağrılı hastalara yönelik girişimlerinin incelenmesi. Atatürk Üniversitesi Hemşirelik Yüksekokulu Dergisi 2001;4:7-17.

20. Brown C, Constance K, Bedard D, et al. Colorectal surgery patients' pain status, activities, satisfaction, and beliefs about pain and pain management. Pain Management Nursing 2013;14:184-92.

21. Joshi GP, Kehlet H. Procedure-specific pain management: The road to improve postsurgical pain management? Anesthesiology 2013;118:780-2.

22. Joshi GP, Bonnet F, Kehlet H. Evidence-based postoperative pain management after laparoscopic colorectal surgery. Colorectal Dis 2013;15:146-55.

23. Ay F, Alpar EŞ. Postoperatif ağrı ve hemşirelik uygulamaları. Ağrn 2010;22:21-9.

24. Eti Aslan F, Demir Korkmaz F, Karabacak Ü. Pain in cardiac surgery and the nursing approach. Türk Gögüs Kalp Damar Cerrahisi Dergisi 2012;20:172-6.

25. Yıldırım YK, Uyar M. Etkili kanser ağrı yönetimindeki bariyerler. Ağrı 2006;18:12-9. 
26. Zeitz K, McCutcheon H. Policies that drive the nursing practice of postoperative observations. Int J Nurs Stud 2002;39:831-9.

27. Kim YJ, Park HA. Analysis of nursing records of cardiac-surgery patients based on the nursing process and focusing on nursing outcomes. Int J Med Inform 2005;74:952-9.

28. Darawad MW, Al-Hussami M, Saleh A, et al. Jordanian patients' satisfaction with pain management. Pain Management Nursing 2012;27:1-10.

29. Gunningberg L, Idvall E. The quality of postoperative pain management from the perspectives of patients, nurses and patient records. Journal of Nursing Management 2007;15:756-66.
30. Milutinovic D, Milovanovic V, Pjevic M, et al. Assessment of quality of care in acute postoperative pain management. Vojnosanit Pregl 2009;66:156-62.

31. Abdalrahim MS, Majali SA, Stomberg MW, et al. The effect of postoperative pain management program on improving nurses' knowledge and attitudes toward pain. Nurse Education in Practice 2011;11:250-5. 


\title{
Prophylactic Use of Non-invasive Ventilation After Abdominal and Thoracic Surgery
}

\author{
Non-invazif Ventilasyonun Abdominal ve Torasik Cerrahi Sonrası Profilaktik Kullanımı
}

\author{
Ayșe Nur Yeksan', Cafer Mutlu Sarıkaș', Ürfettin Hüseyinoğlu', Sadık Avșar² \\ ${ }^{1}$ Department of Anaesthesiology and Reanimation, Kafkas University School of Medicine, Kars, Turkey; ${ }^{2}$ Department of Chest Diseases, \\ Kafkas University School of Medicine, Kars, Turkey
}

\begin{abstract}
All types of surgeries inevitably cause some sort of respiratory alterations. Postoperative pulmonary complications increase hospital stay, morbidity and mortality and are still significant problems in clinical practice. Nowadays, non-invasive ventilation is in common use and one of its uses is to prevent postoperative pulmonary complications. Thoracic and abdominal surgeries have high risks for pulmonary complications. Thus, we aimed to present a systematic review to analyze the results of prophylactic non-invasive ventilation use after abdominal and thoracic surgeries.
\end{abstract}

Key words: abdomen; non-invasive ventilation; postoperative complications; pulmonary atelectasis; surgery; thoracic surgery

\section{ÖZET}

Tüm cerrahi girișimler kaçınılmaz olarak bazı solunumsal değișikliklere sebep olur. Postoperatif akciğer komplikasyonları hastanede kalım süresi, mortalite ve morbiditeyi arttırırlar ve hala önemli klinik pratik sorunlardır. Bugünlerde, non-invazif ventilasyon kullanımı sıktır ve bir kullanımı da postoperatif akciğer komplikasyonları önlemektir. Toraks ve karın cerrahileri akciğer komplikasyonları açısından yüksek riske sahiptirler. Bunun için, karın ve toraks cerrahisinde koruyucu non-invazif ventilasyonun sonuçlarını incelemek için bir sistematik derleme sunmayı amaçladık.

Anahtar kelimeler: karın; non-invazif ventilasyon; postoperatif komplikasyonlar; pulmoner atelektazi; cerrahi; torasik cerrahi

\section{Introduction}

\section{Definition of Non-invasive Ventilation (NIV)}

In general terms, it is the way of giving mechanical respiratory support to the patient without the support of an artificial airway ${ }^{1}$. During NIV the protective mechanisms of upper airways are still active, and patients can speak, eat and clear their secretions by themselves during application.

The adventure of mechanical ventilation in clinical practice substantially had started with non-invasive method in 1900-1950s when so many polio pandemics had broken out. "Iron lungs" which covered whole body and generated "negative" pressure to assist ventilation saved lives although they were unpractical and unwieldy for routine use. Unfortunately, the mortality rate was still so high which necessitated discovering the positive pressure ventilation support via artificial airways in 1950s.

Initially, it was applied manually, however consequently in a short span of time first generation positive pressure ventilators were already fabricated. NIV or non-invasive positive pressure ventilation (NPPV, a synonym for NIV) using "positive" pressure became a major issue again in 1980 s when nasal continuous positive airway pressure (CPAP) was used in the treatment of sleep apnea. In 1990s, it was also used in the treatment of chronic obstructive lung disease, congestive heart failure and other conditions associated with respiratory insufficiency. Until now, NIV lost nothing from its popularity in clinical practice.
Yard. Doç. Dr. Ayşe Nur Yeksan, Kafkas Üniversitesi Tip Fakültesi, Anesteziyoloji ve Reanimasyon Anabilim Dalı 3600 Kars, Türkiye Tel.05353659095 Email.nur.yeksan@gmail.com

Gelis Tarihi: 07.08.2014 • Kabul Tarihi: 13.08.2014 


\section{Clinical Use of NIV}

NIV does not require the use of an artificially created airway like an intubation tube or tracheotomy cannula; however an interface connecting the patient to the supportive device is needed. A nasal, oro-nasal, full face or helmet mask can be used for this purpose. Any of the masks has its unique advantages and disadvantages, however obviously all require patient compliance during application. NIV support can be provided by a standard positive pressure ventilator, a specialized bilevel positive airway pressure (BiPAP) machine or a CPAP device ${ }^{2,3}$.

CPAP and BiPAP are two main NIV techniques. CPAP delivers a constant positive pressure during both inspiration and expiration, so there is not a separate inspiratory support; that means it improves oxygenation; however its efficacy on ventilation and work of breathing is limited ${ }^{4,5}$. On the other hand, BiPAP delivers two different pressure levels during inspiration and expiration. It helps both oxygenation and ventilation because it gives additional inspiratory support decreasing the work of breathing ${ }^{4,5}$.

Air leak is another important consideration during NIV application. Certainly, it depends on tightly fitting of the mask as well as patient's facial characteristics ${ }^{6}$. Air leaks lead to the loss of patient-ventilator synchronization which causes difficult and ineffective applications ${ }^{7}$. Ordinary intensive care ventilators are also used for NIV, however they don't provide a good synchrony if they don't have a leak compensation algorithm ${ }^{8}$. Besides, NIV ventilators have the ability of generating high flows and reducing patient-ventilator asynchrony, are improved over time and better than many intensive care ventilators for compensating air leaks?.

Although NIV is used in a wide variety of clinical situations in intensive care and emergency units, clinical trials and meta-analysis recommend its use in only four clinical situations with grade $1 \mathrm{~A}$ evidence ${ }^{10}$ :

1. Severe exacerbation of chronic obstructive lung disease.

2. Cardiac edema and respiratory failure in the absence of shock or acute coronary syndrome requiring acute coronary revascularization.

3. Facilitating extubation in chronic obstructive pulmonary disease (COPD) patients that cannot be weaned from the ventilator.

4. Acute respiratory failure in immune-compromised patients.
Obstructive sleep apnea is the most common breathing disorder and compromises upper airway muscle activity. Anesthetic drugs also compromise the same activity and the situation is worse postoperatively for patients having obstructive sleep apnea. NIV is a preferable option for these patients peri-operatively, even for a better wound healing because it provides a better oxygenation $^{11,12}$.

Asthma exacerbations, hypoxemic respiratory failure, extubation failure and post-operative respiratory failure are also among the clinical situations in which NIV is used. Ferrer et al. demonstrated superiority of NIV use in extubation failure patients compared to classical weaning protocol ${ }^{13}$.

Certainly, there are contraindications and complications of NIV application. Severe hypoxemia or acidemia, multi organ failure, anatomical face problems, severe agitation, copious secretion, uncontrolled vomiting, repetitive hemoptysis and hematemesis, upper airway obstruction, encephalopathy, impaired consciousness, apnea, cardiac arrest and patient's refusal of application are among contraindications. Thus, in most instances NIV use is contraindicated in the situations which we cannot control the airway safety and hemodynamic stability.

NIV is a quite safe and well tolerated technique for appropriate patients in proper conditions and can be used for short and long times. Adverse side effects usually are not so serious and they are mostly related to the mask, or flow and pressure levels of the ventilator. Some of the side effects related to mask use are discomfort, erythema on face, nasal ulceration and claustrophobia. Nasal congestion, ear pain, mouth/nose dryness, cornea irritation and gastric distension are among the complications related to flow and pressure. Besides; air leak, aspiration pneumonia, hypotension, pneumothorax are also among undesirable states. Clinicians must be careful about abdominal distension in patients having upper gastrointestinal anastomosis. Although it is never a contraindication for NIV use, it is always conflictive among anesthesiologists and surgeons.

\section{Postoperative Pulmonary Complications (PPC)}

All types of surgeries regardless of anesthesia choice (general or regional) cause some sort of respiratory alterations. PPC can simply be defined as any pulmonary abnormality observed in the postoperative period. This issue should not be underestimated during daily 
clinical practice because it increases the length of hospital stay, and the rates of morbidity and mortality ${ }^{14}$. Pneumonia, pneumothorax, pulmonary edema, pleurisy, aspiration, infection of airways, respiratory failure can be listed among these complications some of which rely on peri-operative atelectasis formation.

Atelectasis occurs in $90 \%$ of patients who are anesthetized $^{15}$; meaning that even a trouble-free anesthesia and surgery may not prevent atelectasis. Anesthesia leads to atelectasis by reducing functional residual capacity (FRC) which can be interpreted as resistance of lungs against collapse. Depression of the respiratory center by the used drugs, high $\mathrm{FiO}_{2}$, postoperative pain and direct muscle injury related to surgical incision are probably contributing factors ${ }^{16}$. Atelectasis and hypoventilation are most frequent reasons of early postoperative hypox$\mathrm{emia}^{17}$. Anesthetic drugs and neuromuscular blockers, although are easily reversible, have residual effects in the postoperative period, thus the risk of atelectasis also exists in the postoperative period ${ }^{5}$.

There are risk factors increasing the possibility of PPC and, thus, postoperative respiratory failure. Anesthetic factors along with surgical factors, type of surgery (particularly thoracic and abdominal surgeries), demographical factors (age, obesity, etc), and preexisting hypoxemia or lung disease increase the risk of PPC. Approximately $8-10 \%$ of patients need intubation and mechanical ventilation after abdominal surgery ${ }^{18}$. In a multicenter prospective study conducted by Canet et al., $5 \%$ of 2464 patients developed at least one PPC ${ }^{19}$. In addition, cardiac (39.6\%), thoracic (31.4\%) and abdominal surgeries $(7.2 \%)$ were the most complicated surgeries. Highest rates of 30th and 90th day postoperative mortalities and prolonged ventilation requirements were after abdominal surgeries and the length of hospital stay was directly proportional with the number of complications. A comprehensive analysis of the study findings revealed seven independent predictive risk factors for PPC as lower preoperative arterial oxygen saturation, acute airway infection in the preceding month, age, preoperative anemia, upper abdominal or thoracic surgery, surgery duration more than 2 hours and emergency cases ${ }^{19}$.

Besides a proper pain management, oxygen therapy and early mobilization, there are several additional strategies to prevent and treat atelectasis, postoperative hypoxemia and PPC. One of them is PEEP use during surgery. The medical literature consists of studies suggesting that the use of a $10 \mathrm{~cm} \mathrm{H}_{2} \mathrm{O}$ PEEP opens the collapsed alveoli ${ }^{20}$. Rusca et al. added $10 \mathrm{~cm} \mathrm{H}_{2} \mathrm{O}$ CPAP before induction and ensured insignificant atelectasis, even with 10 minutes long $100 \%$ oxygen use during induction ${ }^{21}$. Avoiding the use of high rates of oxygen before and during anesthesia and during recovery from anesthesia is another precaution to prevent atelectasis, because recruitment maneuver used in the management of atelectasis is ineffective in case where $100 \%$ oxygen is given for 10 minutes before extubation $^{22}$. Incentive spirometer and deep inspiration practice before and after surgery are also a way of preventing and treating peri-operative atelectasis. Thomas and McIntosh collected all studies about the effects of deep breath exercise, incentive spirometer and intermittent positive pressure breath on PPC, published from 1966 to 1992 in a meta-analysis ${ }^{23}$. They concluded that all these maneuvers reduced the PPC rate in study groups compared to control groups who were not treated with any of the maneuvers. All of these maneuvers are intended to increase lung volumes just as NIV; so why don't we use NIV for the same purpose?

The curiosity about the probable benefits of NIV gave rise to studies dealing with the prophylactic and curative use of NIV postoperatively and intraoperative$\mathrm{ly}^{14,24}$. Tobias was the first to publish postoperative use of $\mathrm{NIV}^{4}$. He treated acute postoperative respiratory failure associated with NIV in three children and three adults.

Postoperative hypoxemia and acute respiratory failure develop especially after thoracic and abdominal procedures. Although invasive mechanical ventilation is the mainstay of treatment for acute respiratory failure, some studies demonstrated relation between postoperative pulmonary mortality, and re-intubation and mechanical ventilation ${ }^{5}$. NIV provides all benefits of invasive mechanical ventilation and it reduces the risk of airway complications and nosocomial pneumonia at the same time. In addition, it reduces patient's discomfort and prevents airway resistance caused by the intubation tube, and helps to ensure better communication with the patient ${ }^{4}$. In this point of view, first precaution for the clinician is to prevent PPC; however, if it occurs unavoidably, the aim during management is to avoid re-intubation. NIV seems to fit for both purposes, thus is used for both prophylactically and curatively ${ }^{5}$.

Jaber et al. showed that NIV is a safe and well tolerated method in their study of 72 patients who had gastrointestinal surgery and respiratory failure 
postoperatively ${ }^{25}$. In this paper, we aimed to review the prophylactic use of NIV in postoperative periods of abdominal and thoracic surgeries.

\section{Methods}

We thoroughly searched Pubmed, Medline, and Cochrane Library beginning from 1979 January to 2014 June and limited the search within "clinical trials" and "randomized controlled trials". The search terms "thoracic surgery", "abdominal surgery", "thoraco-abdominal surgery" were combined with any of these: "non-invasive ventilation", "non-invasive positive pressure ventilation", "non-invasive respiratory support", "continuous positive airway pressure", "bilevel positive airway pressure". The studies dealing with just the preoperative or intra-operative NIV use, including pediatric patients, cardiac and bariatric surgeries, and in where NIV was applied as negative pressure ventilation or for curative purposes were excluded.

\section{Results}

Twelve studies consisting of a total of 858 patients met the inclusion criteria for final analysis ${ }^{26-35}$. Table 1 summarizes the included studies. Abdominal, thoracic and thoraco-abdominal surgeries were included in eight, two and two studies, respectively. NIV improved arterial blood gases in eight and spirometer data in four studies, and it decreased the rate of atelectasis in three studies.

\section{Abdominal Surgery}

Periodic NIV use immediately after extubation and continuing its use in postoperative period were associated with significantly higher oxygenation rates or faster recovery of lung volumes ${ }^{26,31,32}$. In a study conducted on 65 open laparoscopy operation patients, atelectasis rate was compared to respiratory therapy including incentive spirometer or coughing and deep breathing ${ }^{26}$.

PPC and re-intubation rate were similar when compared to conventional therapy, while arterial oxygenation was improved after NIV use ${ }^{27,28}$.

On the contrary, Carlsson et al. did not find any favorable effect of NIV on arterial oxygenation or spirometer measurements in comparison with the oxygen therapy ${ }^{29}$. In addition, analogously NIV did not lead a shorter hospital stay in 58 patients having abdominal surgery ${ }^{30}$.

Squadrone et al. used NIV for both prophylactic and curative purposes in the same study ${ }^{33}$. They included 209 patients and $1 \%$ of patients (one patient) required intubation in NIV group, while 10\% (ten patients) were re-intubated in the control group. The ICU stay and infection rate were significantly lower in NIV, however the length of hospital stay was not different.

\section{Thoracic Surgery}

Aqulio et al. investigated early effects of NIV after lung surgery in comparison with the conventional treatment. NIV improved arterial oxygenation after onehour application and this effect continued one more

Table 1. The summary of randomized controlled trials dealed with non-invasive ventilation

\begin{tabular}{|c|c|c|c|c|c|c|c|}
\hline Source & Surgery & $\mathrm{N}$ & Rate of Atelectasis & Spirometric Data & Arterial Blood Gas & Intubation rate & Outcome \\
\hline Stock et al. & Elective abdominal surgery & 65 & Favour NIV & Favour NIV & ND & ND & ND \\
\hline Anderes et al. & Elective abdominal surgery & 30 & ND & ND & Favour NIV & ND & ND \\
\hline Böhner et al. & Elective abdominal surgery & 204 & ND & ND & Favour NIV & Favour NIV & ND \\
\hline Carlsson et al. & Cholecystectomy & 24 & No difference & No difference & No difference & ND & ND \\
\hline Denehy et al. & Elective abdominal surgery & 58 & ND & No difference & No difference & ND & No difference \\
\hline Linder et al. & Elective abdominal surgery & 34 & ND & Favour NIV & ND & ND & ND \\
\hline Ricksten et al. & Elective abdominal surgery & 50 & Favour NIV & Favour NIV & Favour NIV & ND & ND \\
\hline Squadrone et al. & Elective abdominal surgery & 209 & ND & ND & Favour NIV & Favour NIV & No difference \\
\hline Aguilo et al. & Elective lung resection & 19 & ND & ND & Favour NIV & ND & ND \\
\hline Perrin et al. & Elective lobectomy & 39 & No difference & No difference & Favour NIV & ND & ND \\
\hline Fagevik et al. & Thoracoabdominal surgery & 70 & ND & No difference & Favour NIV & Favour NIV & No difference \\
\hline Kindgen-Milles et al. & Elective thoraco-abdominal aneurysms & 56 & Favour NIV & ND & Favour NIV & Favour NIV & ND \\
\hline
\end{tabular}


hour after the cessation of the ventilator support and carbon dioxide level and physiological dead space did not change at that moment. The procedure was feasibly tolerable and only one of the patients had considerable pleural air leak ${ }^{34}$.

Perrin et al. applied prophylactic NIV in both preoperative and postoperative periods of the same patients and compared it to oxygen therapy. They tested whether NIV ensures a better gas exchange and pulmonary function after lung resection in patients with a forced expiratory volume lower than $70 \%$ of predicted ${ }^{35}$. Gas exchange and spirometer values were better and hospital stay was lower in NIV group.

\section{Thoraco-abdominal Surgery}

The need for re-intubation and prolonged mechanical ventilation was significantly lower in prophylactic NIV group when compared with the control group in a study enrolling 70 patients in the postoperative period of resection for esophagus or cardia cancer; however gas exchange and lung volumes were similar in both groups ${ }^{36}$.

Kingden-Milles et al. compared prophylactic use of continuous and intermittent NIV after thoracoabdominal aortic aneurysm repair and revealed that oxygenation was better in continuous NIV group ${ }^{37}$. Hospital stay and rate of PPC were significantly lower in continuous NIV group.

\section{Discussion}

This paper reviews randomized controlled clinical trials about prophylactic NIV application in postoperative period of abdominal and thoracic surgery starting from 1979 to 2014 June, so it is the most extensive review in this sense.

PPC is still an important issue because it is a big burden on the physical and psychological health of patients besides its $\operatorname{costs}^{38}$. NIV is not an old technique to treat or prevent these complications; it has become popular since 1990s. Many reviews actually suggest that patients with higher risks for postoperative respiratory failure; including the individuals who are obese or affected by lung diseases and those undergoing surgical procedures at higher risk of PPC, and patients undergoing cardiac, thoracic or upper abdominal surgery; would benefit from NIV mostly ${ }^{38-40}$. The risk of PPC is highest in cardiac surgery, followed by thoracic and abdominal surgeries ${ }^{19}$. Başoğlu et al. reported \%9-69 risk of PPC occurrence after upper abdominal surgery, and the rate did not decrease despite improvements in anesthetics and surgical technologies through years ${ }^{41}$.

Hypoxia occurs in $30-50 \%$ of postoperative abdominal surgery patients, even after an uncomplicated surgery and anesthesia, and 8-10\% them need re-intubation and mechanical ventilation in the postoperative care unit ${ }^{5,18}$. NIV, particularly in prophylactic use, can be brilliant and miraculous. Besides, it is cheap, safe, practical and well-tolerated by the patients.

To be honest, the medical literature lacks studies recommending the routine prophylactic use of NIV in the postoperative periods of thoracic and abdominal operations. However, the results of currently performed studies seem to be mostly on NIV's favor. They show better findings of arterial blood gas and spirometer values, and atelectasis rate. Thus, NIV still has the chance for being within the recommendations of practice guidelines. However, we still do need more prospective studies with larger sample sizes in order to achieve stronger evidence to recommend NIV's routine use in the postoperative period.

In addition, atelectasis rate was dependent on the radiological findings in the previous studies and the clinical outcomes were not thoroughly evaluated. Thus, further prospective studies are needed to identify the true rate of atelectasis and its clinical implication.

Some clinicians have concerns about using NIV in gastrointestinal surgery and mostly they think that NIV may cause anastomosis leak. However, the literature lacks any serious complication resulted from NIV.

In conclusion, prophylactic NIV use after thoracic or abdominal surgery is still an untouched topic to be studied on. It seems that it has the potential for use in routine daily practice; however our hypothesis should be tested with more prospective clinical studies.

\section{References}

1. Özcan Ergin P, Noninvazif Ventilasyon. In: Dikmen Y, editör. Mekanik Ventilasyon, 1st ed. İstanbul: Güneş Kitabevleri; 2012:107-14.

2. Hillberg RE, Johnson DC. Noninvasive ventilation. New Engl J Med 1997;337:1746-52.

3. Rabatin JT, Gay PC. Noninvasive ventilation. Mayo Clin Proc 1999;74:817-20.

4. Tobias JD. Noninvasive ventilation using bilevel positive airway pressure to treat impending respiratory failure in the postanesthesia care unit. J Clin Anesth 2000;12:409-12.

5. Jaber S, Chanques G, Jung B. Postoperative noninvasive ventilation. Anesthesiology 2010;112:453-61. 
6. Cereda M, Neligan Patrick J, Reed Amy J. Noninvasive respiratory support in the perioperative period. Current Opinion in Anaesthesiology 2013;26:134-40.

7. Vignaux L, Vargas F, Roeseler J, et al. Patient-ventilator asynchrony during noninvasive ventilation for acute respiratory failure: A multicenter study. Intensive Care Med 2009;35:840-6.

8. Vignaux L, Tassaux D, Carteaux G, et al. Performance of noninvasive ventilation algorithms on ICU ventilators during pressure support: A clinical study. Intensive Care Med 2010;36:2053-9.

9. Certaux G, Lyazidi A, Cordoba-Izqierdo A, et al. Patient ventilator asynchrony during noninvasive ventilation: A bench and clinical study. Chest 2012;142:367-76.

10. Keenan SP, SinuffT, Burns KE, et al. Clinical practice guidelines for the use of noninvasive positive-pressure ventilation and noninvasive continuous positive airway pressure in the acute care setting. CMAJ 2011;183:195-214.

11. Rennotte MT, Baele P, Aubert G, et al. Nasal continuous positive airway pressure in the perioperative management of patients with obstructive sleep apnea submitted to surgery. Chest 1995; 107:367-74.

12. Adasenya AO, Lee W, Greilich NB, et al. perioperative management of obstructive sleep apnea. Chest 2010;138:1489-98.

13. Ferrer M, Esquinas A, Arancibia F, et al. Noninvasive ventilation during persistent weaning failure: a randomized controlled trial. Am J Respir Crit Care Med 2003;168:70-6.

14. Chiumello D, Chevallard G, Gregoretti C. Non-invasive ventilation in postoperative patients: A systematic review. Intensive Care Medicine 2011;37:918-29.

15. Gunnarsson L, Tokics L, Gustavsson H, et al. Influence of age on atelectasis formation and gas exchange impairment during general anaesthesia. Br J Anaesth 1991;66:423-32.

16. Özyilmaz E, Kaya A, Postoperatif hastada gelisen solunum yetmezliginde noninvazif mekanik ventilasyonun yeri. Available from: http://www.tuberktoraks.org/managete/fu_ folder/2012-02/html/2012-60-02-185-192.htm

17. Daley M. D, Norman P. H, Colmenares M. E, et al. Hypoxaemia in adults in the post-anaesthesia care unit. Canadian Journal of Anaesthesia 1991;38:740-6.

18. Nicholau D. The Postanesthesia Care Unit. In: Miller RD, editor. Miller's Anesthesia Volume 2, 7th ed. Philadelphia: Elsevier; 2010:2707-28.

19. Canet J, Gallart L, Gomar C, et al. Prediction of postoperative pulmonary complications in a population-based surgical cohort. Anesthesiology 2010;113:1338-50.

20. Hedenstierna G, Edmark L. The effects of anaesthesia and muscle paralysis on the respiratory system. Intenseive Care Med 2005;31:1327-35.

21. Rusca M, Proietti S, Schnyder P, et al. Prevention of atelectasis formation during induction of general anesthesia. Anesth Analg 2003;97:1835-9.

22. Benoit $\mathrm{Z}$, Wicky $S$, Fischer JF, et al. The effect of increased FiO2 before tracheal extubation on postoperative atelectasis. Anesth Analg 2002;95:1777-81.

23. Thomas JA, McIntosh JM. Are incentive spirometer, intermittent positive pressure breathing, and deep breathing exercises effective in the prevention of postoperative pulmonary complications after upper abdominal surgery? A systematic overview and meta-analysis. Phys Ther 1994n; 74:3-10.
24. Cabrini L, Plumari VP, Landoni G, et al. Intraoperative prophylactic and threpeutic non-invasive ventilation: a systematic review. British Journal of Anaesthesia 2014;112:638-47.

25. Jaber S, Delay J, Sebbane M, et al. Outcomes of patients with acute respiratory failure after abdominal surgery treated with noninvasive positive-pressure ventilation. Chest 2005;128:2688-95.

26. Stock M, Downs J, Gauer P, et al. Prevention of postoperative pulmonary complications with CPAP, incentive spirometer, and conservative therapy. Chest 1985;87:151-7.

27. Anderes C, Anderes U, Gasser D, et al. Postoperative spontaneous breathing with CPAP to normalize late postoperative oxygenation. Intensive Care Med 1979;5:15-21.

28. Bohner H, Kindgen-Milles D, Grust A, et al. Prophylactic nasal continuous positive airway pressure after major vascular surgery: results of a prospective randomized trial. Langenbecks Arch Surg 2002;387:21-6.

29. Carlsson C, Sonden B, Thylen U. Can postoperative continuous positive airway pressure (CPAP) prevent pulmonary complications after abdominal surgery? Intensive Care Med 1981;7:225-9.

30. Denehy L, Carroll S, Ntoumenopoulos G, et al. A randomized controlled trial comparing periodic mask CPAP with physiotherapy after abdominal surgery. Physiother Res Int 2001;6:236-50.

31. Lindner KH, Lotz P, Ahnefeld FW. Continuous positive airway pressure effect on functional residual capacity, vital capacity and its subdivisions. Chest 1987;92:66-70.

32. Ricksten SE, Bengtsson A, Soderberg C, et al. Effects of periodic positive airway pressure by mask on postoperative pulmonary function. Chest 1986;89:774-81.

33. Squadrone V, Coha M, Cerutti E, et al. Continuous positive airway pressure for treatment of postoperative hypoxemia: A randomized controlled trial. JAMA 2005;293:589-95.

34. Aguilo R, Togores B, Pons S, et al. Noninvasive ventilatory support after lung resectional surgery. Chest 1997;112:117-21.

35. Perrin C, Jullien V, Vénissac N, et al. Prophylactic use of noninvasive ventilation in patients undergoing lung resectional surgery. Respir Med 2007;101:1572-8.

36. Fagevik Olsen M, Wennberg E, Johnsson E, et al. Randomized Clinical study of prevention of pulmonary complications after thoraco-abdominal resection by two different breathing techniques. Br J Surg 2002;89:1228-34.

37. Kingden-Milles D, Muller E, Buhl R, et al. Nasal-continious airway pressure reduces pulmonary morbidity and length of hospital stay following thoraco-abdominal aortic surgery. Chest 2005;28:821-8.

38. Shander A, Fleisher LA, Barie PS, et al. Clinical and economical burden of postoperative pulmonary complications: patient safety summit on definition, risk reducing interventions, and preventative strategies. Crit Care Med 2011;39:216-72.

39. Eichenberger A, Prilotti S, Wicky S, et al. Morbid obesity ad postoperative pulmonary atelectasis: an underestimated problem. Anesth Analg 1999;95:1788-92.

40. Xue FS, Li BW, Zhang GS, et al. The influence of surgical sites on early postoperative hypoxemia in adults undergoing elective surgery. Anesth Analg 1999;88:3-19.

41. Başoğlu O, Bacakoğlu F, Ersin S, et al. Üst karin cerrahisinde postoperatif solunumsal komplikasyon riskinin preoperative parametrelerle iliskisi. Toraks Dergisi 2000;2:17-22. 


\title{
Transitional Cell Carcinoma Recurrence in the Nephrostomy Tract After Percutaneous Nephrolithotomy
}

\section{Perkütan Nefrolitotomi Sonrasında Nefrostomi Hattında Transizyonel Hücreli Karsinom Rekürrensi}

\author{
Mustafa Sofikerim', Mert Ali Karadağ², Emrecan Akınsal ${ }^{3}$, Fikret Halis ${ }^{3}$ \\ ${ }^{I}$ Department of Urology, Acıbadem University Faculty of Medicine, Istanbul, Turkey; ${ }^{2}$ Department of Urology, Kafkas University \\ Faculty of Medicine, Kars, Turkey; ${ }^{3}$ Department of Urology, Erciyes University Faculty of Medicine, Kayseri, Turkey
}

\begin{abstract}
Local seeding of the nephrostomy tract has been theorized as a potential risk of percutaneous management of upper urinary tract tumors. Few cases of nephrostomy tract seeding have been reported. We report a case of nephrostomy tract tumor seeding after percutaneous nephrolithotomy.
\end{abstract}

Key words: carcinoma; neoplasm; nephrostomy; percutaneous; seeding; transitional cell

ÖZET

Üst üriner sistem tümörlerinin perkütan yöntemle tedavisinde, nefrostomi hattına tümör ekilmesi potansiyel bir risktir. Literatürde, az sayıda olgu bildirilmiștir. Bu yayında, perkütan nefrolitotomi sonrasında, nefrostomi hattına tümör ekilen bir olgu sunduk.

Anahtar kelimeler: karsinom; neoplazi; nefrostomi; perkütan; ekim; transizyonel hücreli

\section{Introduction}

Transitional cell carcinoma (TCC) of the upper urinary tract often presents a diagnostic and therapeutic challenge. It is relatively uncommon and accounts for $5-10 \%$ of all renal tumors and less than $5 \%$ of all urothelial tumors ${ }^{1}$. The gold standard treatment of upper tract TCC is nephroureterectomy with excision of bladder cuff ${ }^{2}$. However, endoscopic management may be an alternative treatment option in patients with small and low grade tumors and in case where renal sparing surgery is necessary due to a solitary kidney, renal insufficiency or bilateral disease ${ }^{1}$.

Yard. Doç. Dr. Mert Ali Karadă̆, Kafkas Üniversitesi T⿰р Fakültesi, Üroloji Anabilim Dal, Kars, Türkiye, Tel.05325584324Email.karadagmert@yahoo.com

Geliş Tarihi: 28.11.2013 • Kabul Taribi: 20.02.2014
Local tumor seeding of the nephrostomy tract has been theorized as a potential risk of percutaneous management of upper tract tumors and only a few cases of nephrostomy tract seeding have been reported ${ }^{3}$. In this paper, we report a case of nephrostomy tract tumor seeding after percutaneous nephrolithotomy (PCNL) in a patient with stone disease and incidental upper tract TCC.

\section{Case Report}

A 52-year-old male patient was referred to our department with complaints of long lasting left flank pain and intermittent hematuria. Intravenous pyelography (IVP) and urinary tract ultrasound examinations revealed multiple areas compatible with renal stones in middle and lower calyces of the left kidney and grade one hydronephrosis of the ipsilateral kidney. The examination of right side was unremarkable. In addition, there was not any evidence suggesting malignancy.

PCNL was performed in order to remove the renal stones. Intraoperatively, cystoscopic examination was unremarkable. After the removal of the stones, we performed an excisional biopsy of the structure resembling a tumor through the nephroscope, and completed the operation after placing a percutaneous nephrostomy tube. Pathologic evaluation of the biopsy from renal pelvis revealed a transitional cell carcinoma (TCC) and an open nephroureterectomy was performed 14 days after the initial PCNL. Operative specimen was $1.5 \times 2 \mathrm{~cm}$ in diameter and reported as low grade, stage T1N0M0 TCC. Stone type was calcium oxalate monohydrate. Following retrospective assessment, we realized that it was a long standing stone for 10 years. 
Four months after the surgery the patient experienced pain in the left flank incision line. Computerized tomography examination revealed a $2.5 \times 3.1 \mathrm{~cm}$ solid mass between the left flank inferior muscles (Figure 1). We resected the mass with its surrounding muscle tissues (Figure 2). Pathologic evaluation revealed the metastasis of the high grade TCC. Thus, an adjuvant chemo and radiotherapy program was scheduled.. Focal tumors were detected in the urinary bladder at control cystoscopy; thereby, complete transurethral resection and 6 courses of intravesical BCG instillations were performed due to high grade stage T1 TCC in bladder.

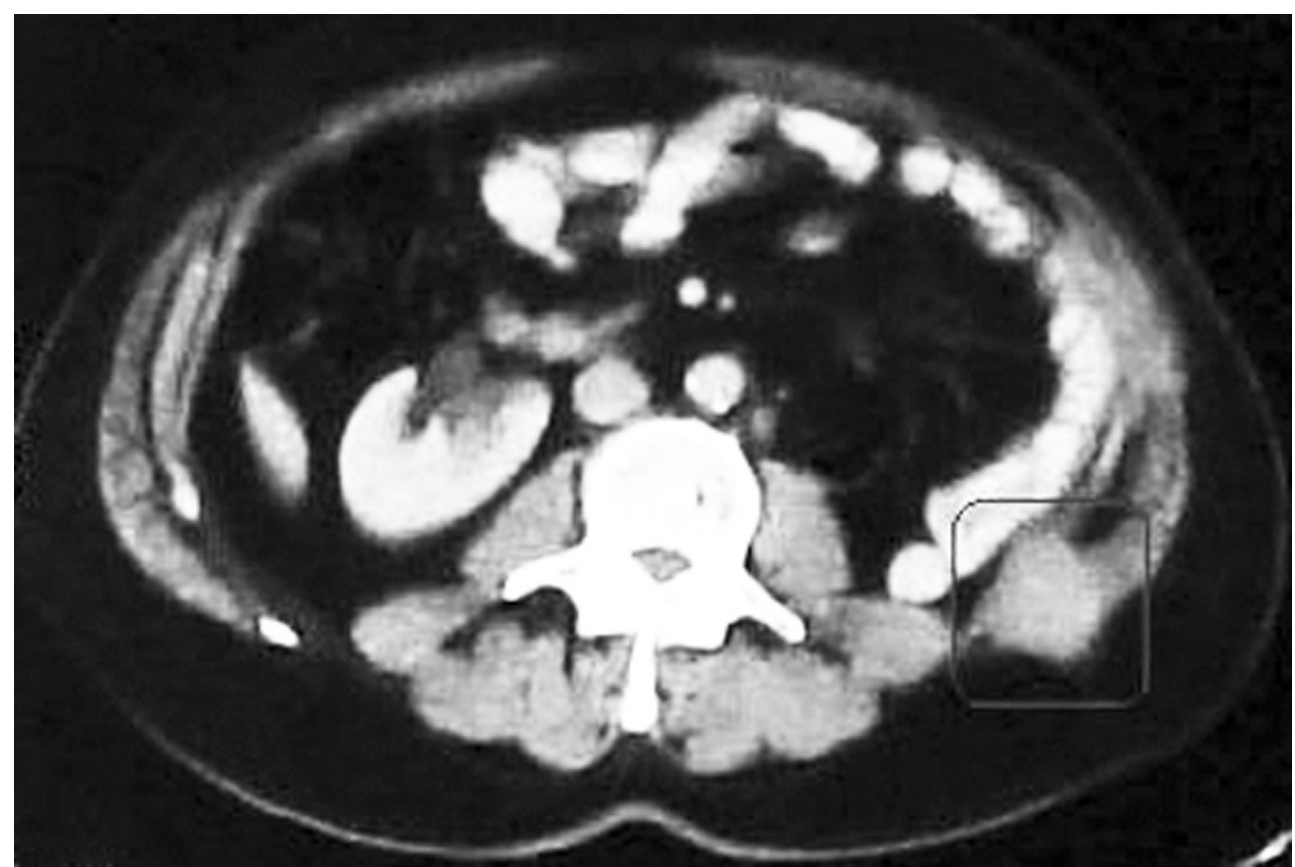

Figure 1. Computerized tomography image of the solid mass between left flank muscles (Surrounded with Blue colour).

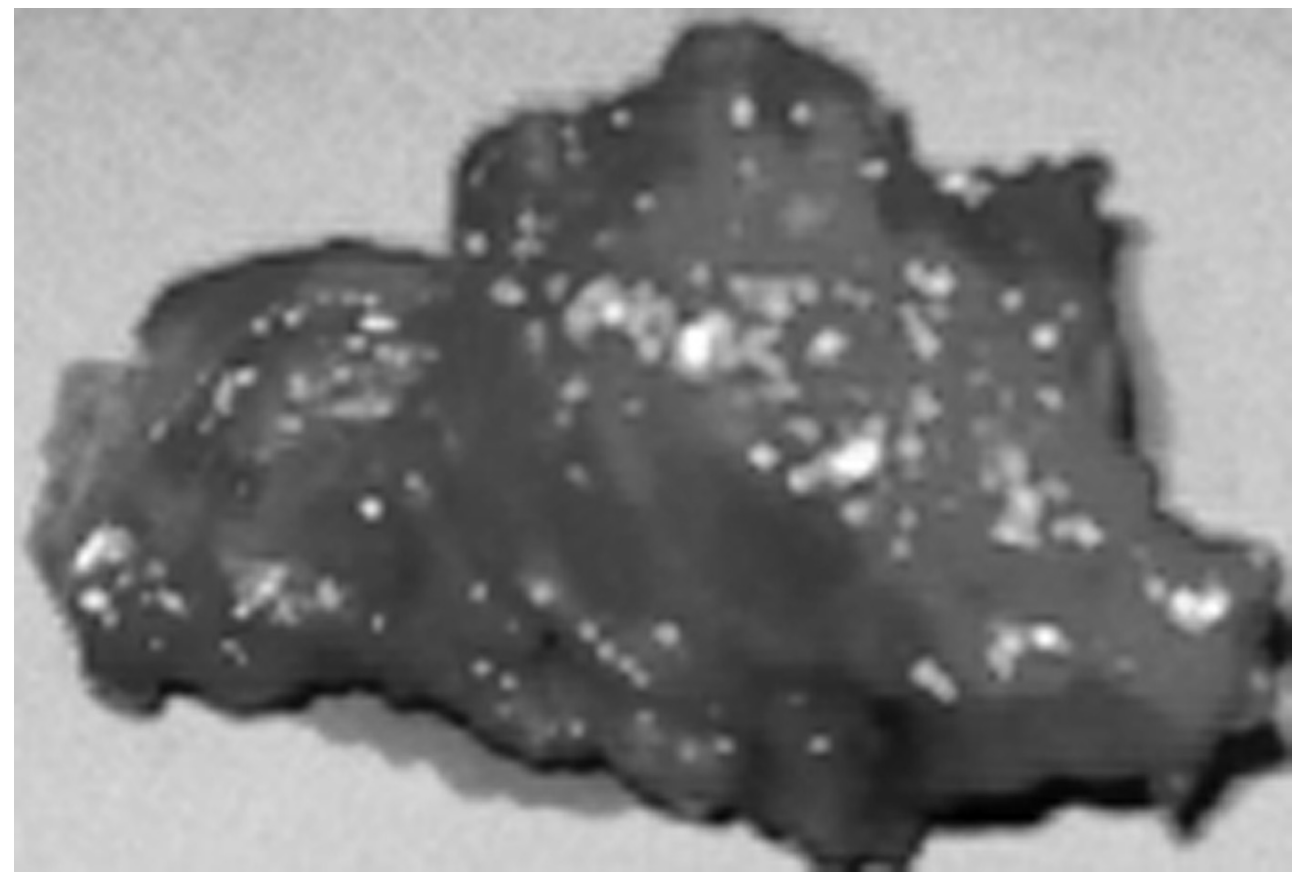

Figure 2. Macroscopic image of the tissue resected from the nephrostomy tract. 
At the sixth month follow up visit, CT examination revealed a $3 \times 3 \mathrm{~cm}$ mass lesion adjacent to spina iliaca anterior superior and multiple metastatic nodules in the lungs. The patient was referred to oncology department for additional chemotherapy and he died following secondary chemotherapy at 18 th month after surgery.

\section{Discussion}

Nephroureterectomy with excision of bladder cuff has been the treatment of choice for upper urinary tract TCC in patients with a normal contra lateral kidney ${ }^{4}$ and the most important prognostic factors are the stage and grade of the tumors 5 . Albeit low-stage and low-grade tumors tend to be associated with good survival after either radical or nephron-sparing surgery ${ }^{6}$, high-grade and high-stage tumors can be controlled in a difficult manner by nephroureterectomy ${ }^{7}$. Although the tumor presented here was a low-grade one, the outcome was poor, probably due to the tumor seeding at the nephrostomy tract.

The discordance between the pathologic grade of the operative specimens (nephrouretercetomy and nephrostomy tract) was re-evaluated in conjunction with the pathologists once again. A dismissed small high grade TCC foci in renal pelvis, ureter or bladder was thought to be an explanation. Actually, bleeding, clots or stone dust observed frequently during PCNL might have obscured the small tumor foci of our patient during the initial evaluation.

Although, we examined the urinary tract using ultrasound and intravenous pyelography prior to the surgery, we did not use contrast enhanced CT scan of the abdomen which would detect the tumor mass in the left renal pelvis.

Endoscopic management of upper urinary tract cancers is an option for patients with low grade/low stage tumors requiring nephron sparing surgery. Successful resection/fulguration of upper tract tumors has been reported with recurrence rates ranging between 0 and $45 \% \mathrm{~s}^{4,8-10}$. Although, the size and stage of the tumor of our patient suggested the choice of endoscopic treatment option, we preferred open nephroureterectomy, as the contra lateral kidney had normal functions.

Tumor seeding in the tract of percutaneous needle aspiration or biopsy has been demonstrated in numerous carcinomas, including prostate, liver, bladder, kidney, gallbladder, and head and neck tumors ${ }^{11-15}$.
However, Tomera et al. reported two cases with local recurrence of transitional cell carcinoma in the renal pelvis, after intraoperative pyeloscopy followed by immediate nephroureterectomy to treat superficial, low grade tumors of the renal pelvis ${ }^{3}$. Although the literature contains a few publication regarding percutaneous tract seeding, our case suggested that endoscopic interventions might result in local recurrence in upper urinary tract TCC's despite low grade and small sized tumors.

Techniques aiming to decrease the risk of access tract seeding have been reported and mostly include the maintenance of a low intrarenal pelvic pressure by using a 30 Fr working sheath and hanging the irrigation solution less than $40 \mathrm{~cm}$ above the level of the patient, use of sterile water as the irrigation solution for its cytolytic effect and resection ${ }^{16}$. Risk may be reduced when endoscopic intervention is performed in a retrograde manner.

The recommended treatment options of TCC following nephroscopic confirmation are nephroureterectomy, adjuvant radiotherapy and immediate resection of the nephrostomy tract ${ }^{17}$. In four patients, Woodhouse et al. prophylactically placed radioactive iridium wires into the nephrostomy tract after percutaneous resection of renal transitional cell carcinoma and none of the patients had tumor cell implantation through the percutaneous tract ${ }^{8}$. We couldn't employ some of these techniques to reduce seeding risk, as we did not have information about tumor existence until nephroscopic examination.

The association of TCC, small cell carcinoma, adenocarcinoma and sarcomatoid carcinoma with renal stone disease has been documented in the literature $^{18-20}$. Urothelial cancer of the renal pelvis in patients undergoing PCNL was studied previously. Of the 500 patients examined during PCNL three patients had urothelial carcinoma of the renal pelvis. The histo-pathological diagnosis was TCC in all cases. In one case the tumor was associated with sarcomatoid features and in another with squamous carcinoma. The overall survival of the three patients was between 2-19 months after the diagnosis of urothelial cancer.

Association of TCC with long standing stone disease has not been studied comprehensively. To our knowledge, the medical literature includes two studies dealing with the relation ${ }^{21,22}$. Kaufmann et al. investigated the effects of long standing catheters and stones on carcinogenesis in patients with spinal cord injuries ${ }^{21}$. 
The authors observed SCC in six patients and TCC in five patients. A similar study including the same kind of patient population reported TCC in six patients and SCC in two patients. However, the concept of the association of renal stones and TCC lacks supporting evidence and needs to be confirmed with more prospective randomized trials.

Long standing calculus may lead to deterioration of renal functions. The pathologic processes identified in a poorly functioning kidney secondary to calculus include chronic pyelonephritis, parenchymal atrophy, xanthogranulomatous pyelonephritis and rarely urothelial carcinomas. Li et al. mentioned that $2 \%$ of their patients with recurrent staghorn calculus had squamous cell carcinoma of the renal pelvis ${ }^{23}$. They also concluded that clinicians should suspect urothelial malignancies in case of a history of long standing stones.

There seems a risk of nephrostomy tract seeding after endoscopic manipulation of urothelial carcinomas of upper urinary tract. Comprehensive preoperative evaluation may lower the risk in patients with renal stones.

\section{References}

1. Huffman JL. Management of upper tract transitional cell carcinomas. Genitourinary oncology 2 nd edition. Philadelphia: Lippincott Williams \& Wilkins; 2000.

2. Mazeman E. Tumors of the upper urinary calyces, renal pelvis and ureter. Eur Urol 1976;2:120-6.

3. Tomera KM, Leary FJ, Zincke H. Pyeloscopy in urothelial tumors. J Urol 1982;127:1088-9.

4. Blute ML, Segura JW, Patterson DE, et al. Impact of endourology on diagnosis and management of upper urinary tract urothelial cancer. J Urol 1989;141:1298-301.

5. Tawfiek ER, Bagley DH. Upper tract transitional cell carcinoma. Urology 1997;50:321-9.

6. Murphy DM, Zinke H, Furlow WL. Primary grade 1 transitional cell carcinoma of the renal pelvis and ureter. J Urol 1980;123:629.

7. Murphy DM, Zinke H, Furlow WL. Management of high grade transitional cell carcinoma of the renal tract. J Urol 1981;125:25.
8. Woodhouse CR, Kellett MJ, Bloom HJ. Percutaneous renal surgery and local radiotherapy in the management of renal pelvic transitional cell carcinoma. Br J Urol 1986;58:245-9.

9. Streem SB, Pontes EJ. Percutaneous management of upper tract transitional cell carcinoma. J Urol 1986;135:773-5.

10. Orihuela E, Smith AD. Percutaneous treatment of transitional cell carcinoma of the upper urinary tract. Urol Clin N Amer 1988; 15:425.

11. Burkholder GV, Kaufman JJ. Local implantation of carcinoma of the prostate with percutaneous needle biopsy. J Urol 1966;95:801-4.

12. John TG, Garden OJ. Needle track seeding of primary and secondary liver carcinoma after percutaneous liver biopsy. HPB Surg 1993;6:199-203.

13. Breul J, Block T, Breidenbach $\mathrm{H}$, et al. Implantation metastasis after a suprapubic catheter in a case of bladder cancer. Eur Urol 1992;22:86-8.

14. Yamakawa T, Itoh S, Hirosawa $\mathrm{K}$, et al. Seeding of gallbladder carcinoma along the tract after percutaneous transhepatic choledochoscopy. Am J Gastroenterol 1983;78:649-51.

15. Huang DT, Thomas G, Wilson WR. Stomal seeding by percutaneous endoscopic gastrostomy in patients with head and neck cancer. Arch Otolaryngol Head Neck Surg 1992;118:6589.

16. Oefelein MG, MacLennan G. Transitional cell carcinoma recurrence in the nephrostomy tract after percutaneous resection. J Urol 2003;170:521.

17. Clark PE, Streem S. Endourologic management of upper tract transitional cell carcinoma. AUA Update Series 1999;18: lesson 16.

18. Katz R, Gofrit ON, Golijanin D, et al. Urothelial cancer of the renal pelvis in percutaneous nephrolithotomy patients. Urol Int 2005;75:17-20.

19. Raghavendran M, Rastogi A, Dubey D, et al. Stones associated renal pelvic malignancies. Indian J Cancer 2003;40:108-12.

20. Jain A, Mittal D, Jindal A, et al. Incidentally detected squamous cell carcinoms of renal pelvis in patients with staghorn calculi: case series with review of the literature. ISRN Oncology 2011;2011:620574.

21. Kaufmann JM, Fam B, Jacobs SC, et al. Bladder cancer and squamous metaplasia in spinal cord injured patients. J Urol 1977;118:967-72.

22. Bickel A, Culkin DJ, Wheeler JS. Bladder cancer in spinal cord injury patients. J Urol 1991;146:1240-4.

23. Li MK, Cheung WL. Squamous cell carcinoma of the renal pelvis. J Urol 1987;138:269-71. 


\title{
Non-Traumatic Pseudocyst of the Spleen: A Case Report
}

\author{
Dalağın Travmatik Olmayan Psödokisti: Bir Olgu Sunumu
}

\author{
Metin Șenol, Hakan Özdemir, İbrahim Tayfun Șahiner, Zehra Ünal Özdemir \\ General Surgery Clinics, I. Şevki Atasagun Nevşehir State Hospital, Nevşehir Turkey
}

\begin{abstract}
Splenic cysts are seen rarely in surgical practice and most of them are parasitic cysts (hydatid cyst). Non-parasitic cysts are classified as true and false cysts (pseudocyst). Pseudocysts are usually secondary to trauma or hemorrhage of spleen. They are believed to be the final stage of organization of an intra-splenic hematoma and are hardly differentiated from hydatid cyst preoperatively. Surgery is the treatment of choice in symptomatic cysts, particularly with a diameter of larger than $5 \mathrm{~cm}$. In this paper, we present a $12 \mathrm{~cm}$ splenic cyst of a 32-year-old male. Pathological examination after total splenectomy via laparotomy revealed splenic pseudocyst. However, the medical history of the patient was unremarkable and there wasn't any history of trauma.
\end{abstract}

Key words: pseudocyst; spleen; splenectomy

\section{ÖZET}

Cerrahi pratikte dalak kistleri nadir görülürler ve çoğu da parazitik kistlerdir (hidatit kist). Parazitik olmayan kistler gerçek ve yalancı kistler (psödokist) olarak sınıflandırılırlar. Psödokistler genellikle dalaktaki travma ya da kanamaya ikincildirler. Dalaktaki hematomun organizasyonunun son basamağı olduklarına inanılırlar ve operasyon öncesi hidatit kistten güçlükle ayırt edilebilirler. Belirti veren, özellikle $5 \mathrm{~cm}$ 'den büyük kistlerin tedavi seçeneği cerrahidir. Bu yazıda, 32 yașındaki bir erkekteki 12 cm'lik dalak kistini sunuyoruz. Laparotomi ile total splenektomi sonrası yapılan patolojik incelemede dalak psödokisti tanısı konuldu. Ancak, hastanın tıbbi geçmișinde belirgin bir özellik ve travma öyküsü yoktu.

Anahtar kelimeler: psödokist; dalak; splenektomi

Uzm. Dr. Metin Senol, İ. Sevki Atasagun Nevşehir Devlet Hastanesi, Genel Cerrahi Kliniği, Nevşehir, Türkiye, Tel.03842285050Email.drmetinsenol@gmail.com Geliş Taribi: 31.10.2013 • Kabul Taribi: 08.02.2014

\section{Introduction}

Splenic cysts are divided into two groups: primary (true) and secondary (false). Primary cysts have epithelial or endothelial lining which is absent in secondary cysts. Primary splenic cysts are classified as parasitic or non-parasitic and most of them are parasitic cysts resulted secondary to Echinococcus granulosus infestation. Non-parasitic cysts may have epithelial covers as epidermoid, dermoid and mesothelial cysts have, or endothelial covers as hemangiomas and lymphangiomas have. Epidermoid cysts account for $90 \%$ of primary non-parasitic cysts. Secondary cysts, also named as pseudocyst, usually develop after an abdominal trauma, and less frequently as a result of mononucleosis, tuberculosis or malaria ${ }^{1,2}$.

False cysts are also called as pseudocyst because they do not have capsules. Trauma is the most common etiological factor. They are believed to be the final stage of organization of an intra-splenic hematoma. In this paper, we present a $12 \mathrm{~cm}$ splenic cyst of a 32-year-old male. Pathological examination after total splenectomy via laparotomy revealed splenic pseudocyst. However, the medical history of the patient was unremarkable and there wasn't any history of trauma.

\section{Case Report}

A 32-year-old man complaining of a left sided abdominal pain was admitted to our clinic. He has had abdominal distension, fullness in the epigastrium, nausea and vomiting for the last few months. Physical examination revealed a mass in the left upper quadrant of the abdomen. The medical and surgical histories were 
unremarkable and there was not any history of trauma or parasitic infection.

Laboratory tests including complete blood count, liver and kidney function tests revealed measurements within normal reference ranges. A calcified mass was seen in the spleen during the abdominal plain X-ray examination (Figure 1), thus we ordered a computerized tomography (CT) to examine the spleen. CT scan revealed a $12 \mathrm{~cm}$ cystic mass in spleen with peripheral calcifications compatible with a hydatid cyst (Figure 2). However, serologic testing for Echinococcus was negative.

Since the cyst was larger than $5 \mathrm{~cm}$ and the patient had worsening of the symptoms, we preferred surgical treatment. Preoperatively, the patient had a Pneumococcus vaccine.

During intra abdominal exploration via median vertical incision, we saw a very large cyst, almost entirely covered by splenic parenchyma, and thus we preferred total splenectomy instead of perforation or aspiration of the cyst. Postoperative follow up was uneventful. Oral nutrition was started on postoperative day one and the patient was discharged on postoperative day three.

Postoperative pathologic examination revealed a 12 $\mathrm{cm}$ splenic pseudocyst with a peripherally calcified wall lacking epithelial lining. The cyst was surrounded by a thin splenic parenchymal layer. The diameters of the splenectomy material were measured as $18 \times 16 \times 12 \mathrm{~cm}$ (Figure 3).

\section{Discussion}

Splenic cysts are rarely seen in daily surgical practice. They are commonly seen in children and young adults. Szczepanik et al. reported that the number of splenic cysts constituted 11 (3.8\%) of all 290 patients

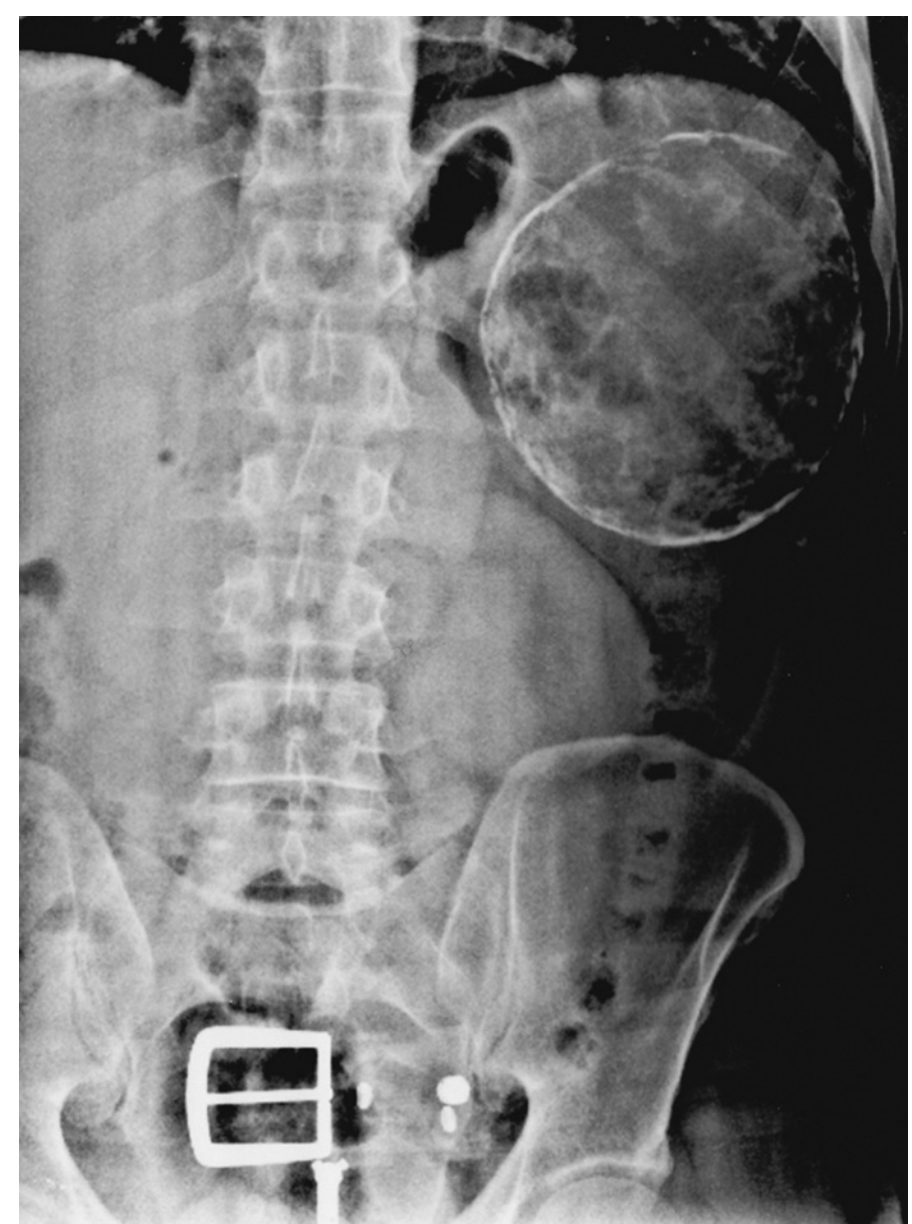

Figure 1. Plain X-ray examination of spleen demonstrating a calcified mass. 


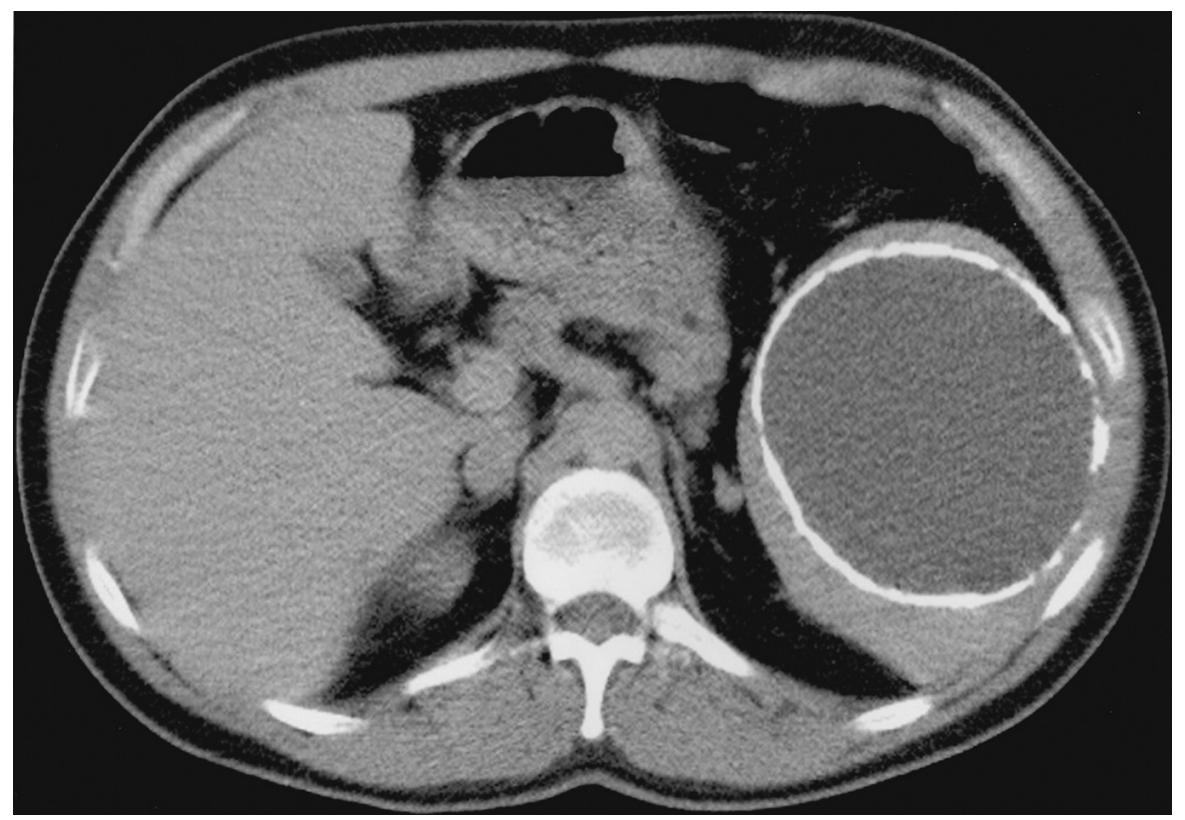

Figure 2. Abdominal CT scan demonstrating a $12 \mathrm{~cm}$ cystic mass with peripheral calcifications.

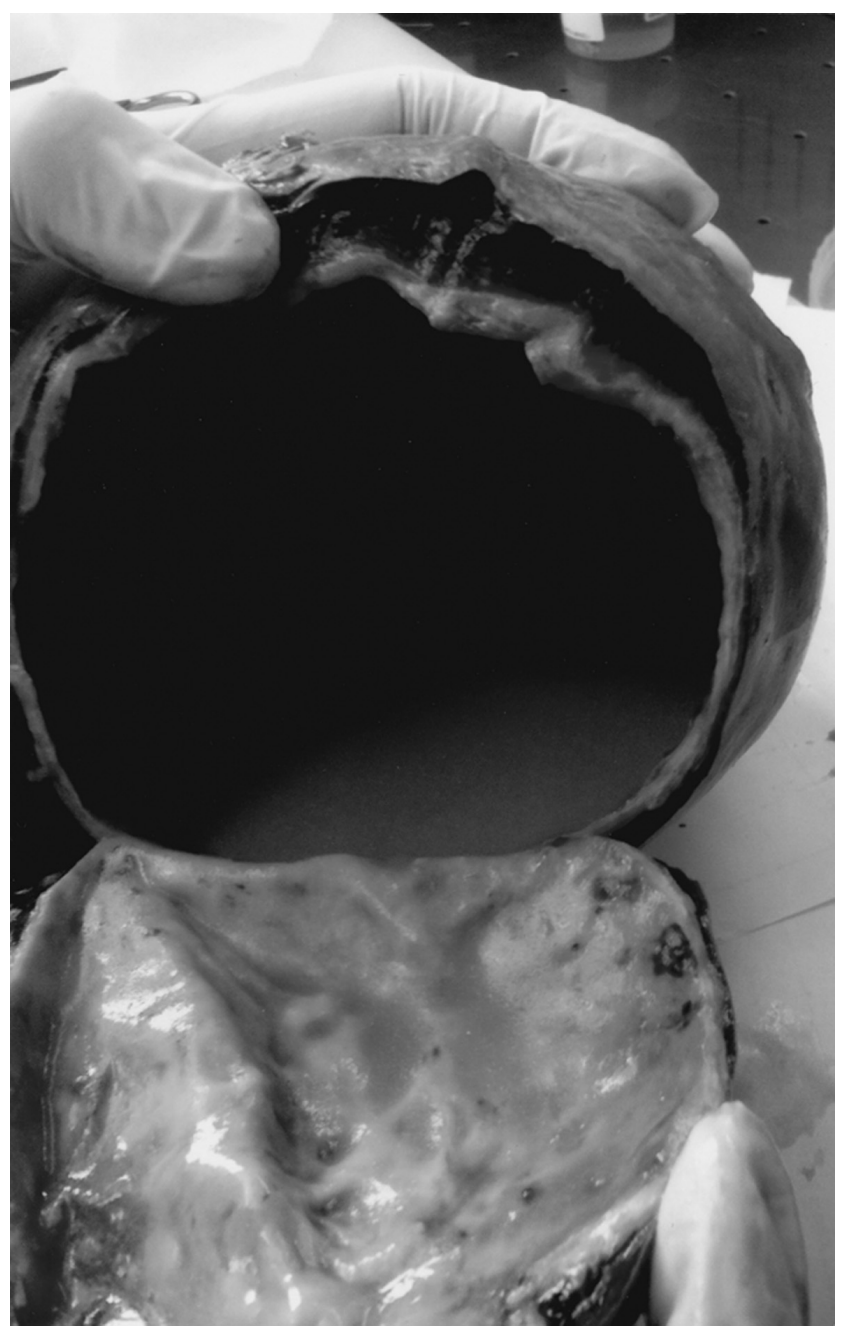

Figure 3. Splenectomy specimen including the pseudocyst. 
subjected to splenectomy during the study period of 4 years ${ }^{3}$. Management of the splenic cyst depends on threefold questioning; What is the nature of the cyst? Should we operate? And which operation will we perform? ${ }^{4}$.

Splenic cysts are more often diagnosed nowadays, probably due to the increased use of abdominal ultrasound and CT examinations. However, it's difficult to distinguish true and false cysts. Most of the splenic cysts are asymptomatic until they reach significant sizes. Large cysts may cause left sided upper abdominal pain and other symptoms of space occupation, secondary to the enlarging cystic mass within the abdominal cavity 5 . Symptomatic cysts and cysts larger than $5 \mathrm{~cm}$, whether symptomatic or not, are generally managed surgically.

Pseudocysts comprise about three-quarters of all non-parasitic cysts of spleen. They are secondary to trauma, infection or infarction. Most are asymptomatic and solitary. They can reach large sizes and contain as much as three liters of dark turbid fluid and are believed to be the final stage of organization of an intra-splenic hematoma. The fibrous capsule often exhibits a chronic inflammatory reaction and contains organized blood clots, with old blood pigment and precipitates of calcium. Macroscopically, they may contain internal debris. Microscopically, these cysts are composed of dense fibrous tissue, often calcified, with no epithelial lining ${ }^{2,6}$.

On plain films of the abdomen, plaque-like calcification is uncommon within true cysts, however it is seen in up to one-quarter of pseudo cysts. CT demonstrates the trabeculations, septations or calcifications of the cyst wall better than the ultrasound can. The diagnosis of a false cyst should be favored, if there is a clear history of trauma, hematoma elsewhere in the spleen, or if the cyst wall is calcified. The differential diagnosis includes echinococcal cyst (often has multiple septations), large solitary abscess or hematoma, or cystic neoplasm of spleen (hamartoma, hemangioma or lymphangioma $)^{7}$.

In distinctive diagnosis of splenic cystic masses, hydatid cysts should rank among first especially in endemic regions, like Turkey. The treatment choice of a splenic hydatid cyst is surgery. Operative approach varies depending on the patient's age, his/her additional systemic diseases, and the location, number and size of the cysts $^{8}$. In our case, the subclass of the cyst was not dem- onstrated accurately preoperatively, thus we preferred to perform a total splenectomy.

Various operative management options for non-parasitic splenic cysts including total splenectomy, partial splenectomy, percutaneous drainage, marsupialization of the cyst and partial cystectomy (fenestration, unroofing) are available. Characteristics of the patients and their cysts contribute in selecting the appropriate management option ${ }^{1}$.

Total splenectomy is still the most preferred surgical procedure used during the management of splenic cysts. However in recent years, the number of surgeons preferring laparoscopic approach is increasing. Total splenectomy performed laparoscopically or open is inevitable in cases where cyst is very large, located in the splenic hilum, covered completely by the splenic parenchyma (intrasplenic cyst), or if there are multiple cysts 5 . Our patient had a cyst located in the splenic hilum and covered entirely by splenic parenchyma. In addition, we could not rule out hydatid cyst.

Awareness of the importance of immunological function of spleen and the potential threat of severe post splenectomy complications have led to the development of splenic parenchyma-preserving surgical procedures. Partial splenectomy is a safe and effective operative procedure used in the management of nonparasitic splenic cysts. It ensures complete cyst removal, prevents cyst recurrence, and preserves the splenic functions ${ }^{3}$. It may be preferred in cases where the cysts are located in splenic poles.

The laparoscopic management of splenic cysts has all advantages unique to laparoscopic surgery including less pain, smaller incision, shorter hospitalization and earlier return to work. Although laparoscopic approach is a minimally invasive technique, it may not provide adequate treatment. The recurrence rates are higher, if large amounts of cyst wall are not removed. The cyst location is the most important factor for performing laparoscopic spleen preserving surgery. Superficial and non-parasitic splenic cysts are better candidates for laparoscopic approach ${ }^{9,10}$.

In conclusion, splenic cysts should be managed surgically, if they are symptomatic or if their diameters are larger than $5 \mathrm{~cm}$. If the presence of a parasitic cyst can't be ruled out preoperatively, total splenectomy is the treatment of choice, particularly in large cysts entirely covered by splenic parenchyma or located in the splenic hilum. 


\section{References}

1. Karfis EA, Roustanis E, Tsimoyiannis EC. Surgical management of nonparasitic splenic cysts. JSLS 2009;13:207-12.

2. Schlittler LA, Dallagasperina VW. Non-parasitic splenic cysts. Rev Col Bras Cir 2010;37:442-6.

3. Szczepanik AB, Meissner AJ. Partial splenectomy in the management of nonparasitic splenic cysts. World J Surg 2009;33:852-6.

4. Cissé M, Konaté I, Ka O. Giant splenic pseudocyst, a rare aetiology of abdominal tumor: a case report. Cases J 2010;3:16.

5. Macheras A, Misiakos EP, Liakakos T. Non-parasitic splenic cysts: a report of three cases. World J Gastroenterol 2005;11:6884-7.
6. Sinha PS, Stoker TA, Aston NO. Traumatic pseudocyst of the spleen. J R Soc Med 1999;92:450-2.

7. Dachman AH, Ros PR, Murari PJ. Nonparasitic splenic cysts: a report of 52 cases with radiologic-pathologic correlation. AJR Am J Roentgenol 1986;147:537-42.

8. Özdogan M, Baykal A, Keksek M. Hydatid cyst of the spleen: treatment options. Int Surg 2001;86:122-6.

9. Matsutani T, Uchida E, Yokoyama T. Laparoscopic unroofing of a large pseudocyst of the spleen: report of a case. J Nippon Med Sch 2009;76:319-22.

10. Fisher JC, Gurung B, Cowles RA. Recurrence after laparoscopic excision of nonparasitic splenic cysts. J Pediatr Surg 2008;43:1644-8. 


\title{
Discrete Papular Lichen Myxoedematosus: A Case Report Diskret Papüler Liken Miksödematöz: Bir Olgu Sunumu
}

\author{
Fatma Pelin Cengiz \\ Department of Dermatology, Kars State Hospital, Kars, Turkey
}

\begin{abstract}
Lichen myxoedematosus is an uncommon, chronic disorder characterized by lichenoid papules due to dermal mucin deposition. Discrete papular mucinosis is a rare subtype of the localized form. Herein, we report a 49-year-old woman with asymptomatic, whitecoloured papules on her upper back. A skin biopsy from a papule on her upper back demonstrated dermal mucin deposition after alcian blue staining.
\end{abstract}

Key words: exanthema; lichens; scleromyxedema; skin.

\section{ÖZET}

Liken miksödematöz, dermal müsin depolanmasından dolayı likenoid papüllerle karakterize olan nadir görülen, kronik bir hastalıktır. Diskret papüler müsinoz lokalize formun nadir görülen bir alt tipidir. Burada, sırtının üst kısmında asemptomatik, beyaz renkli papülleri olan 49 yașında kadın hastayı sunuyoruz. Sırtın üst kısmındaki papülden alınan cilt biyopsisi, Alsian mavisi boyama sonrasında müsin depolanmasını gösterdi.

Anahtar kelimeler: ekzantem; likenler; skleromiksödem; cilt

\section{Introduction}

Cutaneous mucinoses are a wide group of disorders characterized by anomalous deposits of mucin in the skin. Lichen myxoedematosus can be classified into several subtypes, depending on the distribution and overall skin involvement. Discrete papular lichen myxoedematosus (DPLM) is an uncommon subtype of primary cutaneous mucinoses. Only five of the cases described in the literature to date showed no relation

Uzm. Dr. Fatma Pelin Cengiz, Kars Devlet Hastanesi, Dermatoloji Kliniği Kars, Türkiye, Tel.05067015406Email.fpelinozgen@hotmail.com

Geliş Taribi: 17.02.2014 • Kabul Taribi: 11.04.2014 with systemic diseases. Herein, we report the first case of a patient with discrete white papules with mucin deposition that appeared localized to the back.

\section{Case Report}

A 49-year-old woman was referred to our department with asymptomatic papules of 3 months' duration on the upper back. Physical examination revealed numerous well-defined, white papules, 3-5 $\mathrm{mm}$ in diameter (Figure 1). There wasn't any induration or thickening of the skin on the affected site. In addition, there was no history of preceding trauma and the patient was not taking any medication.

Routine laboratory studies were unremarkable. Serum electrophoresis and thyroid function tests were normal. Screening for viral infections remained negative. General physical examination did not reveal any systemic involvement.

A 4-mm punch biopsy was performed from one of the lesions located on the upper part of the back. Histopathological examination showed normal epidermis and widely separated collagen fibers (Figure 2). PAS + Alcian Blue staining showed an increase in blue staining, which indicated an increase in dermal mucin (Figure 3). Based on the clinical, histological and laboratory findings we have diagnosed the discrete papular type of lichen myxoedematosus.

Although topical corticosteroids had been previously administered for three months, they had been ineffective. Because the patient was asymptomatic, we preferred to follow conservatively. During the followup of 20 months, we did not observe any evidence of spontaneous resolution or progression. 


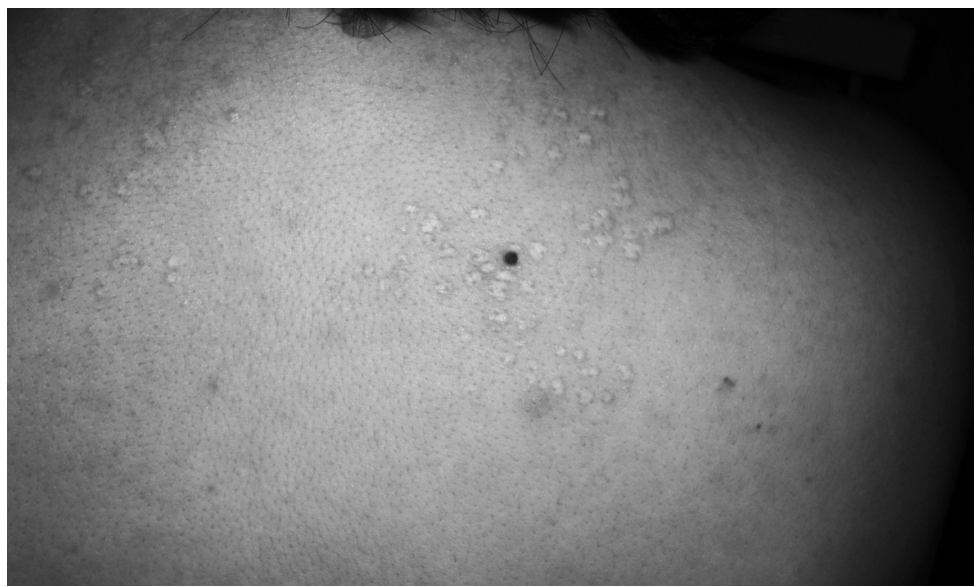

Figure 1. Well-defined, white papules demonstrated on upper site of the patient's back.

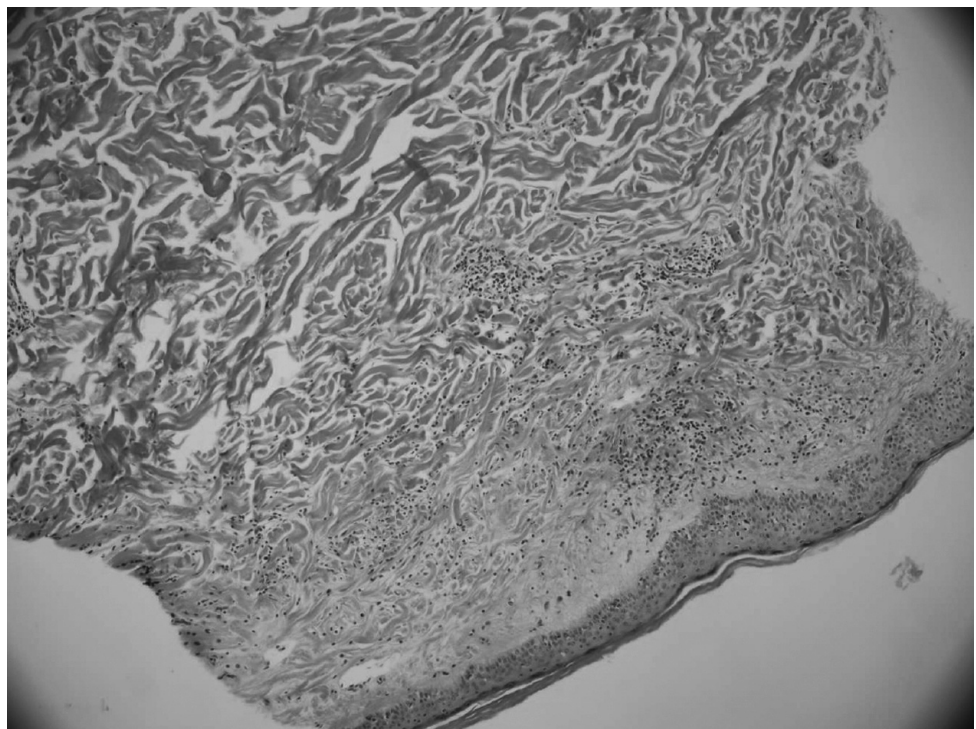

Figure 2. Normal epidermis and widely separated collagen fibers demonstrated in histopathological examination.

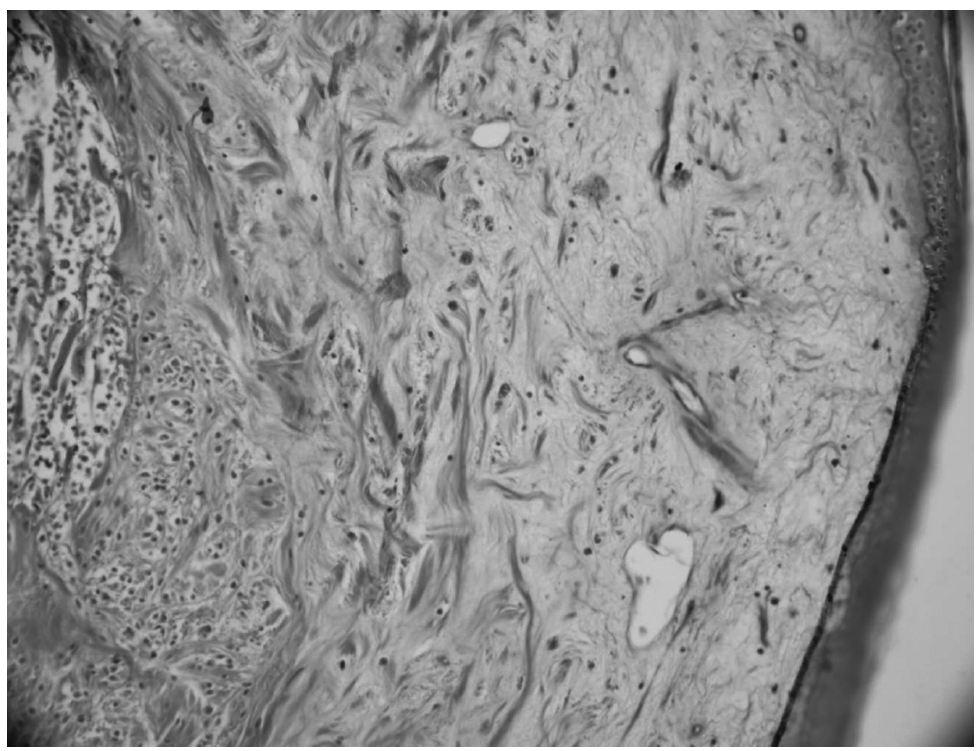

Figure 3. PAS and Alcian Blue staining showed an increase in blue stain indicating an increase in dermal. 


\section{Discussion}

Cutaneous mucinoses are a wide group of disorders characterized by anomalous deposits of mucin in the skin ${ }^{1}$. Lichen myxoedematosus can be classified into several subtypes, depending on the distribution and overall skin involvement. Discrete papular lichen myxoedematosus (DPLM) is an uncommon subtype of primary cutaneous mucinoses ${ }^{2}$.

Papular mucinosis is a rare and chronic disorder which was described by Montgomery and Underwood in $1953^{3}$. The cutaneous focal mucinoses are a group of connective tissue disorders characterized by deposition of mucin found in the middle and deeper layers of the dermis, displacing collagen fibers but not involving the dermal papillae or accumulating around blood vessels ${ }^{4}$.

Rongioletti et al. suggested that lichen myxoedematosus included clinic-pathological subsets: a generalized papular and sclerodermoid form with systemic effects (also called scleromyxedema) and localized papular forms without systemic effects. The localized papular subtype was further subdivided into acral persistent papular mucinosis, papular mucinosis of infancy, selfhealing papular mucinosis and a discrete papular or nodular form ${ }^{2-5}$. We classified our patient as the discrete papular form.

The pathophysiology of cutaneous mucinosis is not well-known. Cytokines, paraproteins, chronic antigenic stimulation, viral infections, and inflammation may contribute to the pathogenesis.

DPLM is a very uncommon type of cutaneous primary mucinosis, which affects both genders equally. There have been only five cases unrelated to systemic diseases reported previously in the literature. Lesions are usually found on the face, neck, trunk or extremities in a symmetrical pattern. Lesions are flesh-colored to erythematous, smooth surfaced and approximately 2-5 $\mathrm{mm}$ in diameter. To the best of our knowledge, this is the first case of discrete papular mucinosis with white colored papules ever reported in the literature.

Cutaneous eruptions may be generalized or localized in papular mucinosis. Systemic organ dysfunction does not occur in localized papular mucinosis. There was no organ involvement in our patient.

The treatment of mucinosis is difficult. Spontaneous healing has rarely been observed. As it is limited to the skin and has little or no morbidity, no systematic treatment approach is an acceptable option ${ }^{5}$. Transition to scleromyxedema has not yet been reported.

In conclusion, we report a case of DPLM in an otherwise healthy woman. The results of clinical examinations and laboratory tests were all negative for conditions typically associated with mucin deposition disorders and our patient had no improvement in her lesions during the follow-up of 20 months.

\section{References}

1. Rongioletti F, Rebora A. The new cutaneous mucinoses: a review with an up-to-date classification of cutaneous mucinoses. J Am Acad Dermatol 1991;24:265-70.

2. Rongioletti F. Lichen myxedematosus(papular mucinosis): new concepts and perspectives for an old disease. Semin Cutan Med Surg 2006;25:100-4.

3. Montgomery $\mathrm{H}$, Underwood LJ. Lichen myxedematosus; differentiation from cutaneous myxedemas or mucoid states. J Invest Dermatol 1953;20:213-36.

4. Black MM, Gawkrodger DJ, Seymour CA, et al. Metabolic and nutritional disorders. In: Champion RH, Burton JL, Burns DA, et al., editors. Textbook of Dermatology. UK: The Blackwell Science; 1998:2616.

5. Rongioletti F, Rebora A. Updated classification of papular mucinosis, lichen myxedematosus, and scleromyxedema. J Am Acad Dermatol 2001;44:273-81. 


\section{AMAÇ VE KAPSAM}

Kafkas Tıp Bilimleri Dergisi (Dergi) Türkçe ve İngilizce yazıımıș makaleleri kabul eden, hakemli bir genel tıp dergisidir. Dergi tıbbi bilimleri geliștiren ve aydınlatan ya da okuyucularını eğiten orijinal biyomedikal makaleleri (Tıp bilimleri ile ilgili araștırma, kısa bildiri, derleme, editöryal, editöre mektup, çeviri, tıbbi yayın tanıtma vb türlerden yazılar) yayımlar. Yılda 3 sayı halinde (Nisan, Ağustos, Aralık) tek cilt olarak, matbu ve elektronik ortamlarda basilır. Dünyanın her yerinden makaleler kabul edilir.

\section{MAKALE GÖNDERME}

Makale toplama ve değerlendirme ișlemleri http://meddergi.kafkas.edu.tr web adresinden online yapııı. Web adresinden giriș yapılmasını takiben "online makale gönder, takip et, değerlendir" butonunun tıklanması ile çıkacak direktiflerin takip edilmesi gereklidir.

\section{ETiK}

Dergi, Yayın Etikleri Komitesi'nin (COPE) rehberlerindeki iyi yayın uygulamaları ilkelerine sıkı bir șekilde bağlıdır (http://publicationethics.org/resources/guidelines). Makale bașvurusunda bulunan yazarlar; çalıșmalarının etik, hukuki ve bilimsel kurallara uygun olduğunu, daha önce yayınlanmamıș ve bașvuru sırasında bașka bir yerde yayınlanmak için değerlendirme așamasında olmadığını kabul ederler. Daha önce yayınlanmıș tablo, șekil ve yazı makalede açıkça belirtilmeli ve yayın haklarını elinde tutanlardan izin alınmalıdır. Dergi, uygun etik kurul bașvurularının yapıımıș olmasını, bilgilendirilmiș onamların alınmasını ve bunların makalede bildirilmesini zorunlu tutar. İnsan öğesini içeren tıbbi çalıșmalarda, Helsinki Deklarasyonu ilkelerine sıkıca bağılır (http://www.wma.net/e/policy/pdf/17c.pdf). Yazarlar, laboratuvar hayvanlarının kullanımında ve bakımında kurumsal ya da ulusal rehberlere uygun davrandıklarını bildirmek zorundadır.

\section{BAȘVURU SIRASINDA ISTENEN MAKALE NITELIKLERI}

Dergi, Uluslararası Tıp Dergileri Editörleri Komitesi'nin (ICMJE) rehberlerine sıkıca bağlıdır ( http://www.icmje.org/index.html). Türkçe makaleler için, Türkçe özete ek olarak İngilizce özet; İngilizce makaleler için, İngilizce özete ek olarak Türkçe özet istenmektedir.

\section{MAKALE HAZIRLANMASI}

Tercihen Times New Romans yazı karakteri, 12 punto ve çift aralıklı yazılması önerilir. Makaleler açık, kısa ve akıcı bir Türkçe veya İngilizce ile yazıımalı, imla kurallarına uyulmalıdır. Dergi, özellikle giriș ve tartıșma kısmı olmak üzere, makale uzunluğunu içerdikleri bilgiyle orantıı ölçüde kısa tutulmasını önerir. Bütün yazarlara bir istatistik uzmanı ile görüșmeleri önerilir.

Bașlangıç Sayfası: Makale bașlığı kısa ve devamlı nitelikte olmalıdır. Bașlık indeksleme ve bilgi toplama açıından yararlı olacak biçimde tanımlayıcı ve bilgi verici olmalıdır. Bütün yazarların ad ve soyadları yazılmalıdır. Her yazar için çalıștığı bölüm, kurum belirtilmeli, iletișim yazarının șehir, ülke ve posta kodunu da içeren tam yazıșma adresi, fax, telefon ve Email adresi sunulmalıdır.

Özet: Özetler anlașıır olmalı ve yazının amaç ve belirgin sonuçlarını gösterebilmelidir. Yalnızca temel bulgu ve sonuçları belirterek, uyarlanmaya gerek duymadan özetleme servislerince kullanılabilmelidir. Araștırma makalelerinde özet bölümü yazısını șu alt bașlıklara (Giriș, yöntem, bulgular, sonuç) göre sıralamak gerekir. Derlemeler,olgu sunumlarında alt bașllk gerekmez. Editöryal, editöre mektup gibi türlerde özetleme yapılmaz. Özetlemede yalnızca standart kısaltmalar kullanılmalıdır.

Anahtar Kelimeler: Yazılya ilgili "Index Medicus: Medical Subject Headings ve Türkiye Bilim Terimleri" standartlarına uygun üç ile altı arası anahtar kelime özet altına yazılıalıdır.

Giriș: Anlașılır ve kısa olmalı, son paragrafında çalıșmanın amacı açıkça belirtilmelidir. Literatürün gözden geçirilmesi çalıșmanın nedenselliğine yönelik olmalı ve önemli bilgileri içermelidir.

Yöntem: Gözlemsel ya da deneysel çalıșma katııımcılarının neye göre seçildiği (hastalar, kontroller ya da laboratuvar hayvanları) açıkça tanımlanmalıdır. Katılımcıların yaș, cinsiyet ve diğer önemli özellikleri belirlenmelidir. İnsan ve hayvanlar üzerinde yapılan çalıșmalarda etik standartlar açıkça tanımlanmalıdır. Yazarlar, diğer araștımacılar tarafından da bulguların tekrarlanabilmesi için yöntem, cihaz ve ișlemleri yeterli açıkıkta tanımlamalıdırlar. İstatistiksel yöntemler de dahil, daha önceden kabul görmüș yöntemler için referanslar sağlanmalıdır. Yeni ya da uyarlanmıș eski yöntemler tanımlanmalı, neden kullanıldıkları ve sınırları açıklanmalıdır. Bütün ilaç ve kimyasallar jenerik isimleri, dozları ve uygulanma yolları sunulmalıdırlar. Randomize kontrollü klinik çalıșmalarda, çalıșmanın ana öğeleriyle ilgili, çalıșma protokolü (çalıșma populasyonu, müdahaleler ya da maruziyetler, beklenen sonuçlar ve istatistik analizin nedenselliği), müdahalelerin belirlenmesi (randomizasyon yöntemi, gruplara ayırmada gizlilik) ve grupların maskelenmesini (körleme) içeren özellikler sunulmalıdır. Yapılan istatistiksel analiz yöntemi belirtilmelidir. Makalenin anlașılması için özellikle gerekli değilse, istatistiksel testlerin ayrıntılarla anlatılması gerekmez. Ancak, özellik arz eden yöntemler kullanıldığında ve makale istatistik ağırlıklı olduğunda ayrıntıı tanımlar gereklidir.

Bulgular: Tablo, șekil ve yazıda sunulan bilgilerin gereksiz tekrarlanmasından kaçınılmalıdır. Yalnızca tartıșma ve ana sonucun anlașılması için gerekli olan önemli bilgiler sunulmalıdır. Veriler bütünlük içinde ve tutarlı olarak sunulmall, raporun açık ve mantıksal ilerlemesi sağlanmalıdır. Tablo ve șekillerdeki veriler yazıda tekrarlanmamalıdır. Yalnızca önemli gözlemler vurgulanmalı ya da özetlenmelidir. Aynı veriler hem tablo hem de grafiklerde sunulmamalıdı. Verilerin yorumlanması tartıșma bölümüne saklanmalıdır.

Tartıșma ve Sonuç: Tartıșma asıl bulguları anlatan kısa ve özlü bir cümle ile bașlamalı, çalıșmanın güçlü ve zayıf yönlerini tanımlamalı, bulguları diğer çalıșmalarla ilișkilendirerek tartıșmalı, olası açıklamalar sağlamalı ve gelecekte yanıtlanabilecek sorulara ișaret etmelidir. Tartıșma, bulgular bölümünde zaten sunulmuș bulguların tekrarıyla değil, bunların yorumlanmasını ile ilgilenmelidir. Yeni bulgularla, zaten bilinenlerin ilișkisini kurmalı ve mantıksal çıkarsamalar yapmalıdır. Sonuç çalıșmanın amacıyla ilișkilendirilebilir ama niteliksiz önermelerden ve verilerle desteklenmeyen sonuçlardan kaçınmak gerekir. Çalıșmanın üstünlüğü konusunda iddialarda bulunmaktan kaçınmak gerekir. Öneriler kesinlikle gerekli ve konuyla ilintiliyse tartıșma bölümünde belirtilmelidir.

Teșekkürler: Teșekkürler kısa ve net olmalı, yalnızca bilimsel/teknik destek ve finansal kaynak için yapıımalıdır. Rutin kurum olanaklarının kullanılması, makale hazırlanmasındaki destek ya da yardımlar (yazma iși ya da sekreterlik ișleri) gibi durumları içermemelidir.

Kaynaklar: Normalde toplam kaynak 30 adet ile sınırlandırımalıdır. Literatüre atıfta bulunan kaynaklar ardısık olarak sıralanmalı ve makalenin sonunda yer almalıdır. Yazının bütününde atıflar üst karakterle cümle bitiminde yer almalıdır. Olabildiğince yazı içinde yazar isimleri kullanmaktan kaçınmak gerekir. Kafkas Tıp Bilimleri Dergisi aynı zamanda ulusal dergilerin kaynak gösterilmesini teșvik eder. Kaynaklar; Index Medicus stiline uygun yapılmalıdır. Üç yazarlıya kadar makale: Halpern SD, Ubel PA, Caplan AL. Solid-organ transplantation in HIV-infected patients. N Engl J Med 2002; 347:284-7. Üçten fazla yazarlı makale: Rose ME, Huerbin MB, Melick J, et al. Regulation of interstitial excitatory amino acid concentrations after cortical contusion injury. Brain Res 2002; 935:40-6. Kitap: Meltzer PS, Kallioniemi A, Trent JM. Chromosome alterations in human solid tumors. In: Vogelstein B, Kinzler KW, editors. The genetic basis of human cancer. New York: McGraw-Hill; 2002:93-113.

Tablolar: Tablolar ayrı olarak yazılmalı ve verilen rakamlar ile sıralanmalıdır. Her tablo kendisi ile ilgili tanımları içermeli ve kısa tanımlayıcı bașlık içermelidir. Tablo içindeki kısaltmalar, tablo altında açıklanmalıdır. Tablo (ilgili bașlık, tanımlayıcı ve açıklayıcı bilgiler) ayrı bir sayfada sunulmalıdır.

Șekiller: Șekiller (ilgili bașlık, tanımlayıcı ve açıklayıcı bilgiler) ayrı bir sayfada sunulmalıdr.

\section{MAKALE DEĞERLENDIRME SÜRECI}

Dergiye sunulan bütün yazılar en az iki hakem tarafından değerlendirme ișlemine alınır. Karar hakem değerlendirme raporlarına göre verilir. Bütün kabul görmüș makaleler dergi kural ve formatına uygun olarak redaksiyon ișlemine tabi tutulur.

\section{SON KONTROL}

Yazının kabulünü takiben yapılacak editöryal ișlemlerden sonra, yazının mizanpajlı șekli yazarların onayına sunulacak ve üç gün içinde telif hakkı devir formu ile birlikte geri istenecektir.

\section{TELIF HAKKI DEVIR FORMU}

Kabul gören yazılar için, ilgili yazar, yayın haklarını dergiye devreden "Telif hakkı devir formu" belgesini sunmakla sorumludur. Telif hakkı devir formu Fax, Email, posta, elden teslim yollarından biriyle dergi sekreteryasına ulaștırılacaktır.

\section{DOI NUMARASI}

Yayımlanan her bir makaleye dijital nesne tanımlayıcı numarası (doi) atanır. 


\section{SCOPE}

The Journal of Kafkas Medical Sciences (KJMS) is a peer-reviewed general medical journal and welcomes manuscripts in Turkish and English. The KJMS publishes original communications of biomedical research that advances or illuminates medical science or that educates the journal readers. It is issued three times per year, and distributed in written form and in electronic format. All manuscripts are accepted throughout the globe.

\section{MANUSCRIPT SUBMISSION}

Manuscripts are submitted online from http://meddergi.kafkas.edu.tr. After registration, authors can send their manuscripts by clicking "online manuscripts submission, follw-up and review" buton placed in web site and following directives written in site.

\section{ETHICS}

KJMS adheres strictly to the Committee of Publication Ethics (COPE) guidelines (http:// publicationethics.org/resources/quidelines) on good publication practice. Authors submitting a manuscriptacceptthat their work contains unpublished work and thatitis not under consideration for publication elsewhere. Previously published tables, illustrations or text should be clearly indicated in the manuscript and the copyright holder's permission must be obtained. Copies of permission letters should be enclosed with the paper. Failure to comply with these guidelines will be considered as a double publishing and treated appropriately. KJMS anticipates appropriate ethical approval and, where relevant, the patients' written informed consent in studies involving humans and animals or human or animal material. KJMS respects to the Declaration of Helsinki for Medical Research involving Human Subjects (http://www.wma.net/e/policy/pdf/17c pdf). The authors should indicate whether the institutional and national guidelines for the care and use of laboratory animals were followed, when reporting experiments on animals.

\section{MANUSCRIPT REQUIREMENTS AT SUBMISSION}

KJMS adheres strictly to the International Committee of Medical Journal Editors (ICMJE) guidelines (see http://www.icmje.org/index.html). For manuscripts in Turkish, in addition to the Turkish version, an English version of the abstract is recommended.

\section{MANUSCRIPT PREPARATION}

Double spacing on one side of the paper only, use preferably Times New Roman 12 point font size. Manuscripts should be written using clear and concise English or Turkish, with English standard spelling and conventions. KJMS advices the authors to restrict the length of manuscripts, especially Introduction and Discussion sections, to the appropriate amounts in relation to the information they contain. It is advisable for authors to refer a statistics expert before final submission.

Title Page: Title of the article should be short (less than 25 words), continuous (broken or hyphenated titles are not acceptable). It should be sufficiently descriptive and informative so as to be useful in indexing and information retrieval. Give initials and family name of all authors. The department, institution and e mail should be supplied for each author. The full postal address, city and country should be given with postal code for the corresponding author, who should be clearly identified. The corresponding phone and fax numbers should be provided.

Abstract: Abstract should be brief (of about 250 words) and indicate the scope and significant results of the paper. It should only highlight the principal findings and conclusions so that it can be used by abstracting services without modification. For original research articles, abstracts should be subdivided into four headings (Introduction, Materials and Methods, Results, Conclusion). No subheadings are required for reviews and case reports. No abstracts are required for editorials and letters to the editor. Only standart abbrevations could be used in abstract section.

Keywords: Between three and six keywords that are suitable with "Index Medicus: Medical Subject Headings and Turkish Scientific Terms" standards should be written under abstract section.

Introduction: Introduction should be brief and state precisely the scope of the paper Review of the literature should be restricted to reasons for undertaking the present study and provide only the most essential background.

Materials and Methods: The selection of the observational or experimental subjects (patients, controls or laboratory animals) should be described clearly. Identify the age sex, and other important characteristics of the subjects. For experiments on human subjects and animals, the followed ethical standards regulated down by the national bodies or organizations of the particular country should be clearly mentioned. The authors should identify the methods, apparatus (list the manufacturer's name and original country in parentheses), and procedures in sufficient detail to allow other workers to reproduce the results. References should be supplied for established methods, including statistical methods. New or substantially modified methods should be described and reasons for using them with their limitations should be provided. All drugs and chemicals should be identified with their generic name (s), dose (s), and route (s) of administration. Reports of randomized clinical trials should include the information on all major study elements including the protocol (study population, interventions or exposures, outcomes, and the rationale for statistical analysis), assignment of interventions (methods of randomization, concealment of allocation to treatment groups), and the method of masking (blinding). The statistical analysis done and statistical significance of the findings when appropriate, should be mentioned. Unless absolutely necessary for a clear understanding of the article, detailed description of statistical treatment may be avoided. Articles based heavily on statistical considerations, however, need to give details particularly when new or uncommon methods are employed.

Results: Unnecessary overlap between tables, figures and text should be avoided. Only such data as are essential for understanding the discussion and main conclusions emerging from the study should be included. The data should be arranged in unified and coherent sequence so that the report develops clearly and logically. Data presented in tables and figures should not be repeated in the text. Only important observations need to be emphasized or summarised. The same data should not be presented both in tabular and graphic forms. Interpretation of the data should be taken up only under the Discussion and not under Results.

Discussion and Conclusion: The discussion should begin with a succinct statement of the principal findings, outline the strengths and weaknesses of the study, discuss the findings in relation to other studies, provide possible explanations and indicate questions which remain to be answered in future research. The discussion should deal with the interpretation of results without repeating information already presented under Results. It should relate new findings to the known ones and include logical deductions. It should also mention any weaknesses of the study. The conclusions can be linked with the goals of the study but unqualified statements and conclusions not completely supported by the data should be avoided. Claiming of priority on work that is ongoing should also be avoided. All hypotheses should, if warranted, clearly be identified as such; recommendations may be included as part of the Discussion, only when considered absolutely necessary and relevant.

Acknowledgements: Acknowledgment should be brief and made for specific scientific/technical assistance and financial support only and not for providing routine departmental facilities and encouragement or for help in the preparation of the manuscripts (including typing or secretarial assistance).

References: The total number of References should normally be restricted to a maximum of 30 . References to literature cited should be numbered consecutively and placed at the end of the manuscript. In the text they should be indicated above the line (superior). As far as possible mentioning names of author(s) under references should be avoided in text. Citations should be made accoridng to Index Medicus Style. Articles with up to three authors: Halpern SD, Ubel PA, Caplan AL. Solid-organ transplantation in HIV-infected patients. N Engl J Med. 2002; 347:284-7. Articles with more than three authors: Rose ME, Huerbin MB, Melick J, et al. Regulation of interstitial excitatory amino acid concentrations after cortical contusion injury. Brain Res. 2002; 935(1-2):40-6. Book Chapters: Meltzer PS, Kallioniemi A, Trent JM. Chromosome alterations in human solid tumors. In: Vogelstein B, Kinzler KW, editors. The genetic basis of human cancer. New York: McGraw-Hill; 2002. p. 93-113.

Tables: Tables should be typed separately and numbered consecutively with Roman numerals (I, II, III, etc). They should bear brief title and column headings should also be short. Abbrevations should be explained under associated table. Tables (short title and descriptive information) should be presented in seperate pages.

Figures: Figures Tables (short title and descriptive information) should be presented in seperate pages. Please note that only file formats with .jpeg extensions could be uploaded to system

Review Process: All papers submitted to KJMS are subject to peer review process by at least two reviewers. Final decision is given by editor according to review results. All accepted articles are subject to redaction according to journal rules and format.

Proofs: Authors are sent page proofs for checking by the production editor after acceptance of the article. Proofs are sent by e mail as PDF files and should be checked and returned within 3 working days of receipt.

Copyright Transfer Agreement Form: Author(s) will be asked to sign a transfer of copyright agreement, which recognizes the common interest that both journal and author(s) have in the protection of copyright. It will also allow us to tackle copyright infringements ourselves without having to go back to authors each time.

DOI Number: A DOI (digital object identifier) number will be allocated to all accepted manuscripts. 
KAFK $\int_{\text {Ornal of Medical Sciences }}$

Yayın Hakları Devir Anlașması Formu

\section{Bu belge bütün yazarlar tarafindan imzalanmalıdır.}

\section{YAYIN HAKLARI DEVIR ANLASMMASI}

Kafkas Tıp Bilimleri Dergisi (KTBD), Kafkas Üniversitesi Tıp Fakültesi tarafından yılda üç defa yayınlanır.

KTBD ve yazarlar aşağıdaki anlaşmaya uyacaklarını bildirirler: İlk defa yayınlanmak üzere aşağıda tanımlanmış özgün makale KTBD’nin incelemesi ve değişikliklerini kabul eder.

Yazının başlığı:

Aşağıda imzası olan yazar(lar) burada bu çalışma ile ilgili sahip oldukları bütün hakları, isimlendirmeleri, çıkarlarını ve sahipliklerini yayınlanma açısından devretmeyi kabul ederler. Bu çalışma yayımlanmak üzere gönderilmiş bütün materyal ve materyal ile ilişkilendirilmiş KTBD’ne gönderilmiş bütün materyali kapsar. Belirtilen çalı̧̧ma KTBD tarafından yayınlanmazsa, yazarlar bilgilendirilecek ve devir edilmiş bütün haklar yazarlara geri dönecektir.

KTBD'ine devredilen haklar, bu anlaşmanın süresinin dolmasından bağımsız olarak, yazıda değişiklikler, yayınlama, çoğaltma, kopyalarının dağıtımı, endekslere sokulması, basılı, elektronik ya da diğer ortamlarda veri tabanlarında aranabilmesi, tüm dünyada yayın hakkını elinde tutması, yayın hakkının yenilenmesi ve süresinin uzatılması haklarını kapsar ama bunlarla sınırlı değildir.

Kabul görmüş bütün işler KTBD’nin malıdır ve KTBD’den önceden izin alınmadan başka bir yerde yayınlanamaz. Yazar(lar) burada çalışmanın yalnızca kendilerine ait olduğunu, bütün yazarların çalışmaya katkılarının olduğunu, çalışmanın en son sonucuna bütün yazarların katıldığını, çalışmanın orijinal olduğunu, başka bir yayında benzer verilerin kullanılmadığını, başka bir kişi ya da kuruma ait yayın hakkı, sahiplik ve kişisel hakların ihlal edilmediğini garanti eder ve bildirirler.

Birinci yazar ad

İmza

İmza

İmza

İmza

İmza

İmza

Imza
Tarih

Tarih

Tarih

Tarih

Tarih

Tarih

Yedinci yazar adı

Telif hakkı devir formu Fax, E- posta, posta, elden teslim yollarından biriyle dergi sekreteryasına ulaștırılacaktır.

Adres: Kafkas Tıp Bilimleri Dergisi,Kafkas Üniversitesi, Tıp Fakültesi, 36300 KARS-TURKEY. Fax: 4742251193 E-mail: meddergi@kafkas.edu.tr

Daha fazla yazar için lütfen bu sayfayı çoğaltarak kullanın. 
KAFK $\int_{\text {Ornal of Medical Sciences }}$

Copyright Transfer Agreement Form

\section{This document must be signed by all authors and submitted with the manuscript. COPYRIGHT TRANSFER AGREEMENT}

The Journal of Kafkas Medical Sciences (KJMS) is published three times a year by Kafkas University School of Medicine, 36200, Kars, Turkey.

The KJMS and Authors hereby agree as follows: In consideration of KJMS reviewing and editing the following describedwork for first publication on an exclusive basis:

Title of manuscript:

The undersigned author(s) hereby assigns, conveys, and otherwise transfers all rights, title, interest, and copyright ownership of said work for publication. Work includes the material submitted for publication and any other related material submitted to KJMS. In the event that KJMS does not publish said work, the author(s) will be so notified and all rights assigned hereunder will revert to the author(s).

The assignment of rights to KJMS includes but is not expressly limited to rights to edit, publish, reproduce, distribute copies, include in indexes or search databases in print, electronic, or other media, whether or not in use at the time of execution of this agreement, and claim copyright in said work throughout the world for the full duration of the copyright and any renewals or extensions thereof.

All accepted works become the property of KJMS and may not be published elsewhere without prior written permission from KJMS. The author(s) hereby represents and warrants that they are sole author(s) of the work, that all authors have participated in and agree with the content and conclusions of the work, that the work is original, and does not infringe upon any copyright, propriety, or personal right of any third party, and that no part of it nor any work based on substantially similar data has been submitted to another publication.

First author's name

Second author's name

Third author's name

Fourth author's name

Fifth author's name

Sixth author's name
Signature

Signature

Signature

Signature

Signature

Signature
Date

Date

Date

Date

Date

Date

Date

Seventh author's name

Copyright form should be returned to the editorial Office by one of the following choices: Fax, E-mail, mail, directly Address: Kafkas Tıp Bilimleri Dergisi,Kafkas Üniversitesi, Tıp Fakültesi, 36300 KARS-TURKEY.

Fax:00904742251193, E-mail: meddergi@kafkas.edu.tr 


\section{İçindekiler / Contents}

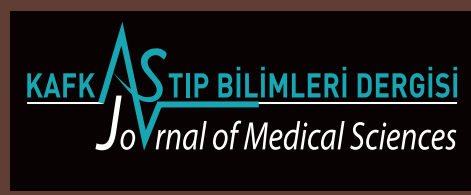

\section{ARASTTIRMA YAZISI / ORIGINAL ARTICLE}

Accessory Nerve Root and Associated Dural Injury Incidences Encountered During Lumbar

Microdiscectomy

Lomber Mikrodiskektomi Esnasında Rastlanan Aksesuar Sinir Kökü ve Dural Yaralanma Sıklığı

Șeyho Cem Yücetaș, Can Hakan Yıldırım, Mehmet Bülent Balioğlu, Yusuf Ehi, Ahmet Faruk Soran, Aytaç Akbașak doi: 10.5505/kjms.2014.83702

Correlation of Cardiovascular Limitations and Symptoms Profile with the Quality of Life, Anxiety and

Depression Scales.

Kardiyovasküler Kısıtılık ve Semptomlar Profilinin Yașam Kalitesi, Anksiyete ve Depresyon Skalaları ile İlișkis

Derya Özcanlı Atik, Sezgi Çınar

doi: 10.5505/kjms.2014.28863

Parotid Kitlelerinin Değerlendirilmesinde İnce İğne Aspirasyon Biyopsisi ile Histopatolojinin

Karșılaștırılması

Comparison of Fine Needle Aspiration Biopsy and Histopathology in the Evaluation of Parotid Masses

Ali Osman Özbey, Fatih Bora, Ahmet Kutluhan, Mahmut Duymuș, Kazım Bozdemir

doi: 10.5505/kjms.2014.96658

Ameliyat Sonrası Ağrı Yönetiminde Nitelik Değișimi: İki Periyodun Karșılaștırılması.

Quality Changes in Postoperative Pain Management: Comparison of Two Periods

Elif Dirimeșe, Meryem Yavuz, Yasemin Altınbaș

doi: $10.5505 / \mathrm{kjms} .2014 .29200$

\section{DERLEME / REVIEW}

Prophylactic Use of Non-invasive Ventilation After Abdominal and Thoracic Surgery.

Non-invazif Ventilasyonun Abdominal ve Torasik Cerrahi Sonrası Profilaktik Kullanımı

Ayșe Nur Yeksan, Cafer Mutlu Sarıkaș, Ürfettin Hüseyinoğlu, Sadık Avșar

doi: 10.5505/kjms.2014.48569

\section{OLGU SUNUMU / CASE REPORT}

Transitional Cell Carcinoma Recurrence in the Nephrostomy Tract After Percutaneous Nephrolithotomy

Perkütan Nefrolitotomi Sonrasında Nefrostomi Hattında Transizyonel Hücreli Karsinom Rekürrensi

Mustafa Sofikerim, Mert Ali Karadağ, Emrecan Akınsal, Fikret Halis

doi: 10.5505/kjms.2014.73645

Non-Traumatic Pseudocyst of the Spleen: A Case Report

Dalağın Travmatik Olmayan Psödokisti: Bir Olgu Sunumu

Metin Șenol, Hakan Özdemir, Ibrahim Tayfun Șahiner, Zehra Ünal Özdemir

doi: 10.5505/kjms.2014.24008

Discrete Papular Lichen Myxoedematosus: A Case Report

Diskret Papüler Liken Miksödematöz: Bir Olgu Sunumu

Fatma Pelin Cengiz

doi: 10.5505/kjms.2014.04706 